

\section{DISCLAIMER}

This report was prepared as an account of work sponsored by an agency of the United States Government. Neither the United States Government nor any agency Thereof, nor any of their employees, makes any warranty, express or implied, or assumes any legal liability or responsibility for the accuracy, completeness, or usefulness of any information, apparatus, product, or process disclosed, or represents that its use would not infringe privately owned rights. Reference herein to any specific commercial product, process, or service by trade name, trademark, manufacturer, or otherwise does not necessarily constitute or imply its endorsement, recommendation, or favoring by the United States Government or any agency thereof. The views and opinions of authors expressed herein do not necessarily state or reflect those of the United States Government or any agency thereof. 


\section{DISCLAIMER}

Portions of this document may be illegible in electronic image products. Images are produced from the best available original document. 


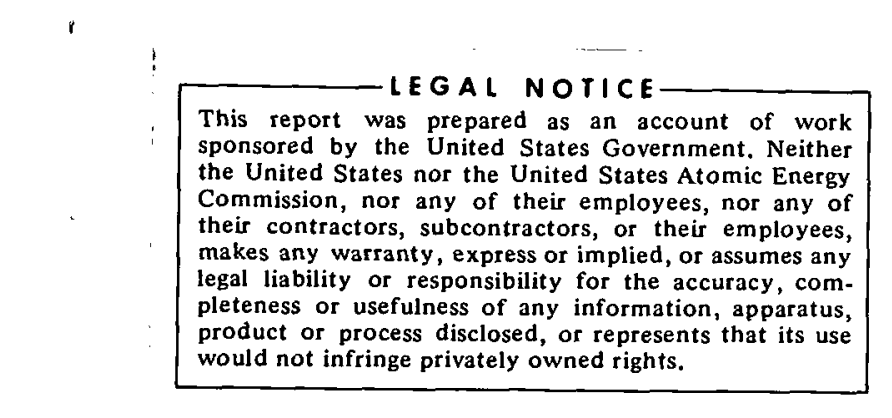

GEAP-10181

AEC Research and Development Report June 1970

\title{
LOW-CYCLE, STRAIN-CONTROLLED FATIGUE CRACK PROPAGATION IN NUCLEAR PIPING STEELS
}

\author{
A. J. Brothers \\ Materials \& Processes Laboratory \\ Schenectady, N. Y.
}

Approved: S.R. Liendeulieng
Approved:

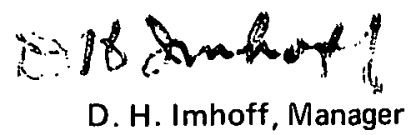

Development Engineering

Prepared for the

U. S. Atomic Energy Commission

Contract AT(04-3)-189

Project Agreement 37

Printed in U.S.A. Available from the Clearing House for Federal Scientific and Technical Information National Bureau of Standards, U.S. Department of Commerce

Springfield, Virginia

Price: $\$ 3.00$ per copy 


\section{LEGAL NOTICE}

This report was prepared as un uccount of Government sponsored work. Neitber the United States,' nor the Commission, nor any person acting on behalf of the Commission:

A. Makes any warranty or representation, expressed or implied, with respect to the accuracy, completeness, or usefulness of the information contained in this report, or that the use of any information, apparatus, method, or process disclosed in this report may not infringe privately owned rights; or

B. Assumes any liabilities with respect to the use of, or for damages resulting from the use of any information, apparatus, method, or process disclosed in this report.

As used in the above, "person acting on bebalf of the Commission" includes any employee or contractor of the Commission, or employee of such contratior, to the extent that such employee or contractor of the Commission, or employee. of sucb contractor prepares, disseminates, or provides access to, any information pursuant to bis employment or contract with the Commission, or bis employment with such contractor. 


\section{TABLE OF CONTENTS}

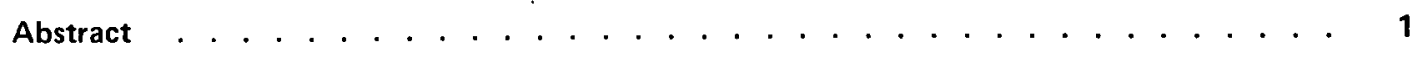

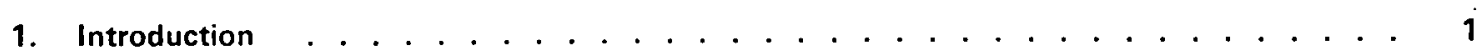

2. General Testing Plan ... . . . . . . . . . . . . . . . 1

2.1. Series A -Crack Growth Rates in Through-Cracked Specimen in Axial Tension-

Compression at Room Temperature . . . . . . . . . . . . . . . . 1

2.2 Series B --Crack Growth Rates of Part-Through Cracked Specimens in Axial Tension-Compression . . . . . . . . . . . . . . . . . i i

2.3 Series C--Crack Growth of Part-Through Surface Cracks in Reverse Bend Loading . . 1

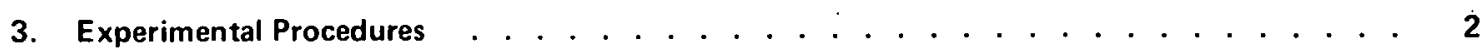

4. Experimental Results . . . . . . . . . . . . . . . . . . . 2

4.1 Series A ..Crack Growth in Through-Cracked Plates in Axial Loading . . . . . . . 2

4.2 Series B -Crowth Rates Under Tension-Compression Loading with Part-Through Surface Cracks . . . . . . . . . . . . . . . . . . . . 6

4.3 Series $\mathrm{C}$-Crack Growth in Bending Tension-Compression Loading of Part-Through Surface Cracks . . . . . . . . . . . . . . . . . . . . . 10

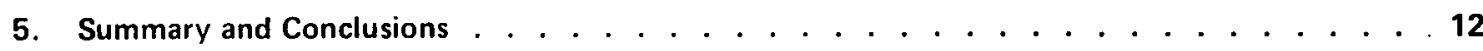

6. lllustrations ........................... 14

APPENDIX

Tabulation of Crack Growth Curves . . . . . . . . . . . . . . . . . . . . . 47

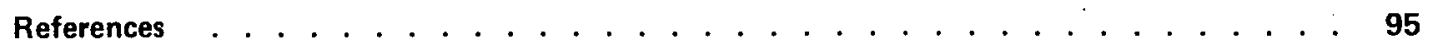

Acknowledgments .......................... 95

Distribution ...................... 96 


\begin{abstract}
Crack growth rates under reversed tension-compression strain-controlled loading were measured for both the axial and bending mode for $\mathrm{A}-212 \mathrm{~B}$ carbon steel, 2-1/4 $\mathrm{Cr}-1 \mathrm{Mo}$ and Type 304 stainless steel at room temperature. Both through-cracked, center-slotted plates and surface-cracked specimens were employed for axial loading, and a surface-cracked specimen for bending tension-compression; these latter specimens were also tested at $550^{\circ} \mathrm{F}$. All results are correlated with the nominal total strain range and, where applicable, with the stress intensity factor, $K$. A method is proposed for correlating geometry effects for low-cycle, strain-controlled fatigue.
\end{abstract}

\title{
1. INTRODUCTION
}

Previous studies (GEAP-5607) of fatigue crack growth in nuclear piping steels determined growth rates for cycling conditions over stress or load-controlled limits; stress levels up to and near the yield stress were evaluated. ${ }^{1}$ For these conditions, it was observed that crack growth rates correlated well with the stress intensity factor calculated from linear elastic fracture mechanics. It was also possible to correlate growth rates for several different geometries in both axial and bending stress fields.

The purpose of this study was to determine similar properties for carbon, 2-1/4 $\mathrm{Cr}-1 \mathrm{Mo}$ and Type 304 steel under cycling conditions for which the specimen is loaded over controlled strain or extension ranges at nominal stresses exceeding yield strength. These are conditions which might result from a limited number of cycles resulting from strains induced by cyclic thermal stresses and/or gross relative displacement of system components. Growth rates were measured using through-crack plate specimens in tension loading, and part-through surface cracks of various geometry in both axial and bending loading. Although most tests were conducted at room temperature, some were performed at $550^{\circ} \mathrm{F}$ to evaluate these properties in the service operating range.

\section{GENERAL TESTING PLAN}

The general aspects of fatigue crack growth considered in this study are described in the following paragraphs.

\subsection{SERIES A-CRACK GROWTH RATES IN THROUGH-CRACKED SPECIMEN IN AXIAL TENSION-COMPRESSION AT ROOM TEMPERATURE}

To establish a reference condition for comparison of the effects of various variables, the primary tests of all materials were performed at room temperatures using a 5 -inch wide plate specimen with a centrally located, 0.5 -inch long, through-slotted plate. These were cycled under axial tension-compression conditions; the variable of initial slot length was explored:

\subsection{SERIES B-CRACK GROWTH RATES OF PART-THROUGH CRACKED SPECIMENS IN AXIAL TENSION-COMPRESSION}

These tests evaluated the influence on crack growth rate of various part-through, semielliptically shaped surface defects. The purpose of these tests was to determine whether simple analytical procedures based on fracture mechanics. principles could correlate results for part-through cracked specimens with those containing through-thickness cracks.

\subsection{SERIES C-CRACK GROWTH OF PART-THROUGH SURFACE CRACKS IN REVERSE BEND LOADING}

To determine the growth rate of part-through surface cracks in bending tension-compression, cantilever beams containing shallow surface slots were loaded in reversed bending tension-compression under conditions of controlled deflection. The specimen used was previously developed, ${ }^{2}$ and is one for which extensive results are available. ${ }^{3}$ However, these test procedures differ somewhat trom those of Crooker and Lange, ${ }^{9}$ who controlled tests to a constant strain range rather than constant deflection. As described in Reference 3, constant-deflection tests produce somewhat higher growth rates; however, the differences are believed to be slight. These results are compared with others on similar material tested under constant strain range. 


\section{EXPERIMENTAL PROCEDURES}

\section{Materials and Test Specimens}

The source, composition and mechanical. properties of the plate materials used are listed in Table 1. Typical microstructural features are shown in Figure 1. "Rolling direction for the 2-1/4 Cr-1 Mo and Type 304 alloys is vertical in the photograph; the orientation of the micrograph for the carbon steel is uncertain. All steels were tested in the as-received conditions without additional heat treatment.

The configurations of the test specimens used are shown in Figure 2 . In all cases, the plate specimens were tested with the axial length of the specimen perpendicular to the rolling direction (i.e., a transverse specimen). The notch in all specimens was prepared by electro-discharge machining; the nominal notch radius specified for through-slot specimens was 0.005 inch.

Cycling was performed in universal testing machines at rates of about 3 to $6 \mathrm{cpm}$. Strain ranges were measured and controlled in the axial specimens (Series A and B) using dual SR4-type extensometers mounted within 1 inch of the edges of the specimen; strain and load range were monitored periodically. For the canntilever bend tests (Serles $C$ ), slidilı yayes weie ylued to the surface of the specimen on both sides of the center slot within $1 / 4$ inch of the edges. Cycling in these tests was deflection-controlled to maintain a deflection identical to that established durıng initıal cyclés with operarlve straln gages. Since these strains for a given deflection may change with cycles as a result of strain hardening or softening, or changing compliance of the specimens, it is doubtful that local strain ranges remain constant throughout the test. Thus, the strains reported are initial strain values only. Loads were monitored periodically to determine the applied tensile and compressive moment required to obtain constant deflection.

Heating for elevated temperature tests was performed using circulating air cabinets. Surface crack lengths in all specimens were measured optically at magnifications to $16 \mathrm{X}$ using a scale graduated in hundred ths of an inch attached to the specimen near the fracture path. Crack depth through the thickness in some of the axial tests containing semielliptical, part-through surface cracks was determined by postmortem examination of fracture surfaces. An understressing technique consisting of about 2000 cycles at low alternating stress was used to mark the crack depth with "optically visible beach marks" at about 0.06 -inch intervals. From these results, it was possible to determine the crack shape at various intervals during crack growth.

Each of the crack growth curves was analyzed to determine the slope (i.e., crack growth rate as a function of increasing surface crack length, $2 a$, or crack depth, c). Increments of crack length or depth, and corresponding cyclic intervals, were taken such that the crack growth curve was ostensibly linear with each increment.

\section{EXPERIMENTAL RESULTS}

The following paragraphs describe the results of the above series of tests. The crack growth data from these tests are tabulated in the Appendix. A summary of crack growth rates is listed in Table 2.

\subsection{SERIES A-CRACK GROWTH IN THROUGH-CRACKED PLATES IN AXIAL LOADING}

The crack growth curves for the through-cracked plates loaded in reversed axial loading are shown In Figures 3 thruugh 5 . Generally, the slope or crack growth rate is constant over short increments of the crack growth curve. The discontinuous changes in slope of some of the curves, as well as the occasional lack of an effect of higher strain range to produce higher growth rates, are believed to reflect either scatter or aberrations in strain control, with an inherently high dependence of crack yruwllı rate on total strain range.

Because of the above anomalies, as well as uncertain transcription of raw data, the author was uncertain regarding the nominal strain range level in initial through-crack plate tests. It was uncertain whether the nominal strain range was equal to

* See Section 6 for all illustrations referenced in text. 
Table 1

SOURCE, COMPOSITION AND MECHANICAL PROPERTIES OF EXPERIMENTAL STEELS

Material: Three 1-inch-thick plates of mill-annealed A-212B steel plate.

Composition:

$\begin{array}{lcccccr} & \text { C } & \text { Mn } & \text { P } & \text { Si } & \text { S } & \mathbf{N}_{2} \\ \begin{array}{l}\text { A-212B } \\ \text { Spec Reg }\end{array} & 0.30 & 0.29-1.06 & 0.048 & 0.10 & 0.058 & - \\ \text { M \& P Lab. Test } & 0.24 & 0.74 & 0.015 & 0.24 & 0.031 & 0.007\end{array}$

Grain Size: ASTM No. 6.5

Microstructure-Fine pearlite-ferrite mixture (Figure 1)

Mechanical Properties (Transverse):

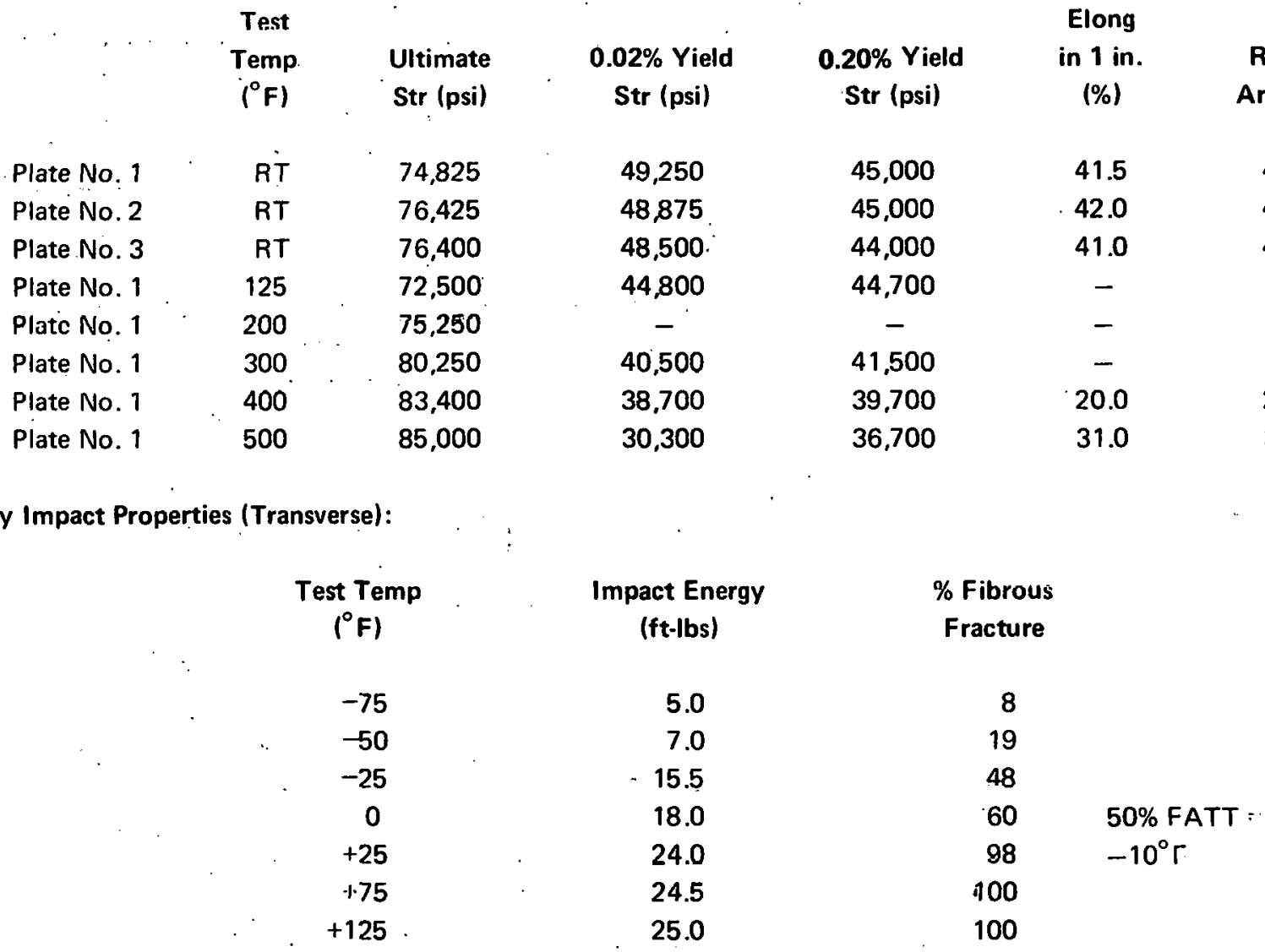


Table 1.-(Continued)

Material: Two plates A-387D, mill-annealed and 2-1/4 $\mathrm{Cr}-1 \mathrm{Mo}$ alloy 1-inch-thick plate.

Heat Treatment: Annealed $1650-1700^{\circ} \mathrm{F}-1.1 / 2 \mathrm{hrs}-\mathrm{FC}$ to $800^{\circ} \mathrm{F}-\mathrm{AC}-\mathrm{SR} 1175^{\circ} \mathrm{F}-1$ hr FC

Composition:

C

A-387D

Spec Reg

Mill Check

M \& P Lab Test $\max$

0.14

0.17

0.15

Mn

$\mathbf{P}$

$0.30-0.60$

0.035

$\max$

0.46

0.011

0.008

0.48

$\mathbf{S}$

Si

0.035

$\max$

0.025

0.019

0.38

0.50

max

0.38

2.30

2.18

Cr

Mo

Grain Size: ASTM No. 5.7

Microstructure: Pearlite-ferrite mixture (Figure 1).

Mechanical Properties (Transverse):

Test Temp
$\left({ }^{\circ} \mathrm{F}\right)$
RT
RT
450
550
600
650

\section{Ultimate \\ Str (psi)}

77,900

78,250

66,500

$6 \overline{8}, 100$

70,250

71,000

\section{$0.02 \%$ Yield \\ Str (psi)}

32,500

26,000

22,250

23,250

22,300

19,700
$0.02 \%$ Yield

Str (psi)

37,000

32,750

23,900

28,650

28,600

28,300
Elong in 1 in.

(\%)

44.0

43.0

38.0

33.0

31.0

32.0
Red in

Area (\%)

66.8

56.8

52.2

49.5

47.5

46.9

Charpy Impact Properties (Transverse):

Test Temp
$\left({ }^{\circ} \mathrm{F}\right)$

0
78
125
150
175
225

Impact Energy

(ft-lbs)

2.5

A.5

26.5

44.0

52.5

63.0
\% Fibrous

Fracture

$\begin{array}{rl}5 & \\ 19 & \\ 42 & \\ 61 & 50 \% \text { FATT }= \\ 89 & +135^{\circ} \mathrm{F} \\ 100 & \end{array}$


GEAP-10181

Table 1.-(Continued)

Material: Two plates A-240, hot-rolled, annealed and pickled Type-304 steel 1-inch-thick plate.

Composition:

$\begin{array}{lcccccccc} & \text { C } & \text { Mn } & \text { P } & \text { S } & \text { Si } & \text { Ni } & \text { Cr } & \text { Mo } \\ \text { A-240 } & 0.08 & 2.00 & 0.03 & 0.03 & 0.75 & 8-11 & 18-20 . & - \\ \text { Spec Reg } & \max & & \max & \max & \max & & & \\ \text { M \& P Lab Test } & 0.07 & 1.63 & 0.016 & 0.013 & 0.54 & 9.50 & 18.57 & 0.26\end{array}$

Grain Size: ASTM No. 3-4

Microstructure - Mixed grain size austenite (Figure 1).

Mechanical Properties (Transverse):

\begin{tabular}{|c|c|c|c|c|c|}
\hline \multirow[b]{2}{*}{$\begin{array}{c}\text { Test Temp } \\
\text { (' } \mathrm{F})\end{array}$} & \multirow[b]{2}{*}{$\begin{array}{l}\text { Ultimate } \\
\text { Str (psi) }\end{array}$} & \multirow[b]{2}{*}{$\begin{array}{c}0.02 \% \text { Yield } \\
\text { Str (psi) }\end{array}$} & \multicolumn{3}{|c|}{ Elong } \\
\hline & & & $\begin{array}{c}0.02 \% \text { Yield } \\
\text { Str (psi) }\end{array}$ & $\begin{array}{c}\text { in } 1 \text { in. } \\
(\%)\end{array}$ & $\begin{array}{l}\text { Red in } \\
\text { Area (\%) }\end{array}$ \\
\hline$R T$ & 79,700 & 26,500 & 34,200 & 83.5 & 72.2 \\
\hline 550 & 63,200 & 13,000 & 17,000 & 63.0 & 70.4 \\
\hline 600 & 63,400 & 14,100 & 17,000 & 64.0 & 71.8 \\
\hline
\end{tabular}

that reported or was, in fact, half that value. Consequently, replicate tests of the $2-1 / 4 \mathrm{Cr}-1 \mathrm{Mo}$ steel were made under carefully controlled conditions, and the results compared with those obtained previously. On the basis of this comparison, it is believed that the strain levels shown for the axial tension-compression tests are valid. However, in view of these anomalies, use of these data is recommended only with the factor of uncertainty noted above. This qualification applies only to the axial tension-compression tests.

Additional crack growth curves for axial tension-compression tests with short initial crack lengths and part-through surface cracks are shown in Figure 6. This figure shows that, prior to penetration, the crack growth rate is quite low and an apparent function of geometry (i.e., crack length). However, after penetration, the crack growth rates are generally similar to those for the through-crack specimens.

Typical illustrations of the load required to obtain a given strain for the center-slotted, axially loaded plates are shown in Figure 7. Generally, the load required to achieve a given strain decreases with increasing crack length (i.e., decreasing net section area). For the higher strain ranges, there is little difference in the load required to achieve a given strain range, and, in some cases higher strain ranges are associated with lower loads. These effects reflect scatter from specimen to specimen, a relatively low effective plastic modulus, as well as the experimental anomalies noted earlier. Although an attempt was made to estimate the expected load level of these curves from stress-strain properties, the uncertainties of cyclic strain hardening effects and yield point phenomena during crack growth made this approach unreasonable. Generally, the observed loads were much higher than those calculated from uniaxial tensile properties.

Typical fracture appearances of the three alloys are shown in Figure 8. These features are similar to those for the stress-controlled tests, with the exception of the extent of crack growth and reduction in thickness with increasing net section sliess. These features, best typified by the Type 3004 steel, show crack growth across the full width of the plate with nil reduction in thickness. This is different from the stress-controlled tests, in which the cyclic crack length rarely exceeded the specimen half-width with considerable reduction in thickness. This feature results from the decreasing load characteristics of llse strain-controlled test 
Table 2.

\section{SUMMARY OF CRACK GROWTH RATES IN AXIALLY LOADED} THROUGH-CRACKED, CENTER-SLOTTED PLATE SPECIMENS

\section{A-212B Carbon Steel}

\begin{tabular}{lll}
$\begin{array}{c}\text { Spec } \\
\text { No. }\end{array}$ & \multicolumn{1}{c}{$\begin{array}{c}\text { Estimated } \\
\text { Strain } \\
\text { Amplitude (\%) }\end{array}$} \\
A & \pm 0.25 & \multicolumn{1}{c}{$\begin{array}{l}\text { Crack Growth Rate } \\
\text { da/dN, inches/cycle }\end{array}$} \\
$B$ & \pm 0.375 & $0.00437-0.00226$ \\
$C$ & \pm 0.15 & 0.019 .1 \\
$D_{1}$ & \pm 0.125 & $0.00095-0.00064$ \\
$D_{2}$ & \pm 0.175 & 0.000116 \\
$F$ & \pm 0.5 & 0.000375 \\
& & 0.0182
\end{tabular}

2-1/4 Cr - 1 Mo Steel

$\begin{array}{lll}A & \pm U .4 & 0.0152 \\ B & \pm 0.4 & 0.0152 \\ C & \pm 0.4 & 0.0374 \\ D & \pm 0.4 & 0.0222 \\ E & \pm 0.3 & 0.00125-0.00191 \\ F & \pm 0.2 & 0.0010-0.00081 \\ G_{1} & \pm 0.125 & 0.000122 \\ G_{2} & \pm 0.15 & 0.000175 \\ G_{3} & \pm 0.20 & 0.00029 \\ H & \pm 0.325 & 0.014 \\ I & \pm 0.125 & 0.000107 \\ J_{1} & \pm 0.15 & 0.00015 \\ J_{2} & \pm 0.20 & 0.000323\end{array}$

Type-304 Stainless Steel

$\begin{array}{lll}\text { A } & \pm 0.09 & 0.000139 \\ \text { B } & \pm 0.125 & 0.0000627 \\ \text { C } & \pm 0.20 & 0.000221 \\ \text { D } & \pm 0.30 & 0.00111 \\ \text { E } & \pm 0.375 & 0.00262 \\ \text { F } & \pm 0.50 & 0.00153\end{array}$

\footnotetext{
4.2 SERIES B-GROWTH RATES UNDER TENSION-COMPRESSION. LOADING WITH PART-THROUGH SURFACE CRACISS

To determine crack growth rates for defect configurations more similar to those anticipated under service conditions, tests were conducted with a 2-1/4 $\mathrm{Cr}-1 \mathrm{Mo}$ steel employing part-through surface cracks of various length-to-depth ratios ranging from 2.5 to 5.0; two thicknesses $(0.25$ inch and 0.8 inch) were tested. These results are shown in Figure 9 as a plot of surface crack length versus number of cycles. Note that, for specimen FS, the crack length plotted is that for growth through the thickness. The crack lengths shown for this specimen are twice the nominally measured value to provide valid comparison for the other specimens in which the crack length represents a total value measured at two growing fronts.
} 
These results indicate that, prior to thickness penetration, surface growth rates are substantially lower than those for through-thickness crack growth and are a function of crack geometry. However, shortly before and after thickness penetration, the crack growth rates are constant and similar to that for a through-thickness slotted plate. The dependence of crack growth rate on crack depth and/or geometry prior to penetration indicates that crack growth rate is not a simple and constant function of gross strain range, and that design based on through-cracked plates could be overly conservative. Conversely, design based on crack growth rates for PTC specimens prior to penetration could (for applications involving through-crack tensile loading) be extremely optimistic.

Typical curves of load as a function of cycles for PTC tests are shown in Figure 10. Generally, the loads required to obtain a given strain range are identical for both tension and compression, suggesting that the isolated location of the strain gages does, in fact, reflect actual specimen strain rather than increased compliance of a cracked specimen. Also, equal loads for tension and compression implies that the crack surfaces are not closing completely during compression (i.e., remain fairly open) and hence are not affecting the load required to obtain a given strain. For example, if the crack were closing fully, one would expect the compressive load to remain constant as a function of increasing crack length. The decrease in load with crack length or number of 'cycles is a simple function of geometry, reflecting lower loads for decreasing net section area. Also, Figure 10 suggests that the load required to obtain a given strain remains fairly constant for crack geometries reasonably small compared to the thickness. For example, the decrease in load with increasing number of cycles is extremely low for PTC 1.0 inch $\times 0.2$ inch for up to 1000 cycles. This suggests that, for nominally small defects, analyses may be based on the assumption of a constant gross stress level, as well as constant strain ranges.

The relation of crack length-to-depth in these tests is shown in Figure 11 and shown qualitatively in the fracture surfaces of Figures 12 and 13. The data of Figure 11 were derived from either beach marks induced by understressing techniques or by dye penetrant marking. Comparison of the surface and depth growth curves of Figure 11 indicates similar growth rates for both surface and depth. Also, inspection of Figure 13 for two specimens with flaw sizes less than the thickness suggests that incipient flaws or cracks tend to assume an equilibrium length-to-depth ratio of about 2.0 to 3.0 . This is generally consistent with previous observations of growth of PTC flaws under cyclic loading (GEAP-5607) and is of significance to analysis of flawed components. ${ }^{1}$

The correlation of crack growth rates for through-slotted plates, and for part-through cracked plates after specimen penetration, are summarized in Figures 14 through 16. Within scatter, these and all previous results suggest a simple exponential relationship between total cyclic strain range and crack growth rate. Although there appears to be little significanit difference between 2-1/4 $\mathrm{Cr}-1 \mathrm{Mo}$ and carbon steel (Figures 14 and 15), the slope of the Type 304 alloy (Figure 16) indicates a significantly lower slope and lower crack growth rates at higher strain levels.

The nominally constant growth rates. (i.e., the linear relationship of crack length to number of cycles for strain-controlled tests of through-cracked plates) differ markedly from those observed for load-controlled tests. In these latter tests, increasing rates are generally observed with increasing crack lengths (GEAP-5607). Since loads were measured in these current strain-controlled tests, and since the through-crack geometry is amenable to analysis by fracture mechanics concepts, these test results were compared with those obtained previously using stress-controlled tests on 14-inch-wide plates (GEAP-5607). ${ }^{1}$ This comparison (shown in Figure 17 for the 2-1/4 Cr-1 Mo alloy, for which the most extensive data are available) illustrates within scatter essentially good agreement between these current strain-cycling tests and prior load-controlled tests. For equal stress intensity factor ranges, crack growth rates are similar. This correlation indicates the relevance of fracture mechanics concepts to rationally correlate crack growth rates under both stress-and-strain-controlled loading. It also provides a basis for predicting the influence of geometry on crack growth rate under strain-controlled loading. This is described further below.

On the basis of the correlation of Figure 17, a rational explanation of the constant growth rate in these strain-controlled tests can be obtained. For example, Figure 18 shows the variation in load, crack length and stress intensity factor with cycles for a through-slot plate test of Type 304 steel. Over the range of crack lengths examined, the stress intensity factor stays nominally constant; thus, (from Figure 17) for near-constant $\mathrm{K}$ levels, one would expect a near-constant crack growth rate. 
Since Figure 17 shows that crack growth rates under stain-controlled loading correlated well with stress-controlled tests on the basis of stress intensity factor, and since this latter quantity includes factors related to geometry, an attempt was made to correlate the incipient crack growth rates in the PTC tests with those measured on through-crack specimens. This correlation, if successful, provides a means of rationally estimating flaw growth of PTC cracks under strain-controlled loading conditions.

From consideration of the general expressions for stress intensity factor, one notes factors of stress, geometry, and crack length; i.e.,

$\begin{array}{ll}\mathrm{K} & =f\left(\sigma_{\mathrm{g}}\right):(f) a, c,: \text { t or } W \\ \text { where } & \\ \mathrm{c} & =\text { crack depth, } \\ \mathbf{a} & =\text { surface half-crack length, } \\ \mathrm{t} & =\text { thickness, } \\ \mathrm{W} & =\text { plate width, and } \\ \sigma_{\mathbf{g}} & =\text { gross section stress. }\end{array}$

Specifically, for a center-slotted plate,

$$
\mathrm{K}=\sigma_{\mathrm{g}} \cdot(\pi \mathrm{a})^{1 / 2}\left[\frac{2 \mathrm{~W}}{\pi \mathrm{a}} \tan \frac{\pi \mathrm{a}}{2 \mathrm{~W}}\right]^{1 / 2}
$$

(References 4 and 5 )

or modification thereof (see Reference 2):

For a part-through surface cracked plate

$$
K=\frac{\sigma_{g} \cdot(\pi c)^{1 / 2}}{\phi_{0}} \cdot[1+0.12(1-c / a)]\left[\frac{2 t}{\pi c} \tan \frac{\pi c}{2 t}\right]^{1 / 2} .
$$

(Refelelite 4)

For a constant streș or corresponding strain level, it is possible to determine the relative, or effective, $K$ or strain level for a given surface crack length in a $\mathrm{PIC}$ specimenin in terms of that ful d ctiltei-slotted plate of equal through crack length. In the extreme, for the case of a part-through crack which penetrates the speclmen thlcklless, the $K$ leviel lüi the PTC plate will equal that of the through-crack plate. Since correlations of crack growth rate versus $K$ or strain range are available for through-cracked plates, the growth rate corresponding to the stress intensity factor or effective strain range in the PTC specimen can be determined; i.e.,

$$
\frac{K_{\mathrm{PTC}}}{\mathrm{K}_{\mathrm{T}}}=\frac{\epsilon_{\mathrm{PTC}}}{\epsilon_{\mathrm{T}}} \quad \text { or } \quad c_{\mathrm{PTC}}=\frac{K_{\mathrm{PTC}}}{K_{\mathrm{T}}} \times \epsilon_{\mathrm{T}}
$$

The results of such an analysis for specimens PTC 1 inch $\times 0.2$ inch and PTC 0.5 inch $\times 0.2$ inch are shown in Table 3 and summarized in Figure 19, which plots both the measured and predicted surface crack growth rate as a function of crack depth. The predicted rates were obtained from the lines shown in Figure 14, using the effective strain range for the PTC specimens.

The correlation shown in Figure 19 is reasonable for crack depths less than about 60 to $75 \%$ of the thickness and suggests that this may be a reasonable analytical procedure for compensating for geometry effects of shallow part-through cracks. However, for crack depths greater than the above depth (see Figures 9 and 11), the growth rate becomes constant and equal to that for the through-thickness crack condition. This effect (i.e., constant crack growth at crack depths less than fult thickness) may reflect the current inadequacy of the stress intensity analysis for part-through cracks of high relative depth. It 
Table 3

SUMMARY OF ANALYSIS OF STRAIN-CONTROLLED

CRACK GROWTH SPECIMENS

PTC 0.5 in. $\times 0.2$ in.

\begin{tabular}{|c|c|c|c|c|c|c|c|c|}
\hline \multirow{2}{*}{$\begin{array}{l}\text { Crack } \\
\text { Depth } \\
\text { c, inches }\end{array}$} & \multicolumn{3}{|c|}{$\begin{array}{l}\text { Crack Half } \\
\text { Length, }\end{array}$} & & \multirow{2}{*}{$\frac{\left\{K / \sigma_{g}\right\} \text { PTC }}{\sqrt{\text { in. }}}}$. & \multirow{2}{*}{$\begin{array}{c}\text { Measured } \\
\text { da/dN } \\
\mu-\text { in./cycle }\end{array}$} & \multicolumn{2}{|c|}{$\begin{array}{c}\text { Estimated } \\
\mathrm{da} / \mathrm{dN}, \mu-\text { inch/cycle }\end{array}$} \\
\hline & $c / t$ & a, inches & $\mathbf{c} / \mathbf{a}$ & $\phi_{0}$ & & & $(\max )$ & $(\min )$ \\
\hline 0.395 & 0.49 & 0.413 & 0.957 & 1.54 & 0.823 & 479 & 630 & 225 \\
\hline $0.495^{\circ}$ & 0.62 & $0 . \dot{5} 88$ & 0.842 & 1.45 & 1.075 & 735 & 850 & 305 \\
\hline 0.565 & 0.706 & 0.695 & 0.812 & 1.42 & 1.30 & 1125 & 1300 & 450 \\
\hline 0.645 & 0.806 & 0.820 & 0.786 & 1.41 & 1.66 & 1390 & 3400 & 820 \\
\hline 0.740 & 0.93 & 0.990 & 0.747 & .1 .38 & 2.92 & 1400 & - & - \\
\hline & & & & & & & & \\
\hline \multicolumn{9}{|c|}{ PTC 1.0 in: $\times 0.2$ in. } \\
\hline 0.338 & 0.422 & 0.563 & 0.601 & 1.28 & 0.916 & 358 & 475 & 165 \\
\hline 0.395 & 0.494 & 0.700 & 0.565 & 1.25 & 1.065 & 680 & 530 & 195 \\
\hline 0.483 & 0.604 & 0.810 & 0.594 & 1.28 & 1.20 & 938 & 610 & 225 \\
\hline 0.662 & 0.827 & 0.950 & 0.697 & 1.34 & 1.89 & 1000 & 3100 & 720 \\
\hline
\end{tabular}

Determination of Effective Strain in PṬC Spec

\begin{tabular}{|c|c|c|c|c|c|}
\hline$\quad \quad \ddots^{\prime} \quad i^{\prime}$ & $\begin{array}{l}\text { Crack Half } \\
\text { Length } \\
a \text {, inches }\end{array}$ & $a / W$ & $\frac{\left\{K / \sigma_{g}\right\} \text { PTC }}{\sqrt{\text { in. }}}$ & $\left\{K / \sigma_{g}\right\} \operatorname{PTC} /\left\{K / \pi_{g}\right\}_{a}$ & $\begin{array}{c}\text { Range in } \\
\text { PTC Spec } \\
\epsilon_{\mathrm{T}} \%\end{array}$ \\
\hline PTC -0.5 in. $\times 0.2$ in. & $\begin{array}{l}0.413 \\
0.583\end{array}$ & $\begin{array}{l}0.083 \\
0.118\end{array}$ & $\begin{array}{l}1.155 \\
1.410\end{array}$ & $\begin{array}{l}0.711 \\
0.763\end{array}$ & $\begin{array}{l}0.284 \\
0.305\end{array}$ \\
\hline$\therefore$ & $\begin{array}{l}0.695 \\
0.820\end{array}$ & $\begin{array}{l}0.139 \\
0.410\end{array}$ & $\begin{array}{l}1.55 \\
1.72\end{array}$ & $\begin{array}{l}0.839 \\
0.965\end{array}$ & $\begin{array}{l}0.335 \\
0.386\end{array}$ \\
\hline PTC -1.0 in. $\times 0.2 \mathrm{im}$ & $\begin{array}{l}0.563 \\
0.700 \\
0.810 \\
0.950\end{array}$ & $\begin{array}{l}0.112 \\
0.140 \\
0.163 \\
0.190\end{array}$ & $\begin{array}{l}1.375 \\
1.560 \\
1.705 \\
2.020\end{array}$ & $\begin{array}{l}0.666 \\
0.683 \\
0.704 \\
0.936\end{array}$ & $\begin{array}{l}0.266 \\
0.2 .3 \\
u .282 \\
0.374\end{array}$ \\
\hline
\end{tabular}

Elfectivè strain in PTC spec $\left.=\left[\left\{\mathrm{K} / \sigma_{\mathrm{g}}\right\} \mathrm{PTC} /\left\{\mathrm{K} / \sigma_{\mathrm{g}}\right\}\right] \mathrm{a}\right] \times \epsilon_{\mathrm{T}} ; \epsilon_{\mathrm{T}}=0.4 \%$. 
is possible that additional analytical consideration beyond the scope of this report, and similar to that described by Kobayashi, ${ }^{6}$ might influence and effectively improve the correlation.

\subsection{SERIES C-CRACK GROWTH IN BENDING TENSION-COMPRESSION LOADING OF PART-THROUGH SURFACE CRACKS}

To determine the influence of bending versus tension loading on the crack growth rates of shallow part-through surface defects, tests of cantilever bend specimens (Figure 2), carbon, and 2-1/4 $\mathrm{Cr}-1$ Mo steels were conducted at room temperature and $550^{\circ} \mathrm{F}$. These results are shown in Figures 20 through 23 . The crack growth curves at room temperature for the carbon steel (Figure 20) and, to a greater extent, the 2-1/4 $\mathrm{Cr}-1$ Mo steel (Figure 21) exhibit increasing crack growth rates with increasing crack length. Although the data points are not shown here, the drawn lines closely reflect the data trends in which extremely low scatter was observed. (Complete crack growth curves are included in the Appendix.)

The crack growth curves for both materials at $550^{\circ} \mathrm{F}$ are shown in Figures 22 and 23 . Also shown on each plot are crack growth curves for $\pm 0.5 \%$ strain range measured at room temperature. Examinaliuri of the results at $6 \mathrm{E} 0^{\circ} \mathrm{F}$ and somparison with rates measured at room temperature indicate lower crack growth rates at the higher temperature for both materials. The observation of lower growth rates in these steels at $550^{\circ} \mathrm{F}$ is different from the effect observed in previous tests of the same material in through-cracked, axially loaded wide plates at similar temperaturss (GFAP-5607). This difference suggests either experimental deficiencies (a specimen geometry effect) or simply the influence of a lower modulus of elasticity at $550^{\circ} \mathrm{F}$. In either case, additional verifying results should be obtained prior to generalization of trends derived from these few tests.

A detailed comparison of test procedures indicates no apparent material dlscreparicies which account for these differences. This comparison revealed the $550^{\circ} \mathrm{F}$ and room temperature specimens to be of identical orientation with no apparent differences in microstructure from those tested at room temperature. The hardnesses of the two sets of carbon steel specimens were essentially identical $(159 \pm \mathrm{BHN})$; the variation in hardness of the 2-1/4 Cr-1 Mo steel (164 $\pm 8 \mathrm{BHN})$ was greater but still possibly within scatter. The details of testing at room temperature and $550^{\circ} \mathrm{F}$ shown in Figures 24 and 25 indicate effects consistent in all respects with observation, but they also indicate a possible discrepancy for the 2-1/4 Cr-1 Mo steel. Generally, total bending moments for the $550^{\circ} \mathrm{F}$ tests are either equal to or greater than the room temperature values; this indicates no obvious error in strain range magnitude, (e.g., if the imposed strain range had been less than the nominal $\pm 0.5 \%$. one would expect a lower rather than a higher applied moment). A possible discrepancy associated with the 2.1/4 $\mathrm{Cr}-1$ Mo results is that of a higher strain range for a short period at the beginning of the test. It is pussible that this effert rinuld, hecause of permanent bending of the bar or strain hardening effects, result in spurious effects. However, even in the initial portions of the test, the nominal crack growth rates are lower than those at room temperature.

Another possible and more reasonable explanation of the reduced growth rates at $550^{\circ} \mathrm{F}$ is the effect of a reduced elastic modulus at that temperature. Since the modulus of elasticity for steel is 20 to $25 \%$ lower at $550^{\circ} \mathrm{F}$ than at room temperature, the resultant plastic strain at $550^{\circ} \mathrm{F}$ for equal total strain ranges will be somewhat lower. If the plastic strain range is the primary variable in effecting crack growth, this would presumably reduce the growth rate.

Typical fracture surfaces of the specimens at room temperature and $550^{\circ} \mathrm{F}$ are shown in Figures 26 and 27 , respectively. These features indicate that the surface crack length-to-depth ratius vary for the two alloys. However, there is no apparent influence of temperature on this feature. The primary differencc between the two steels is that nf lower total crack growth through the thickness in the carbon steel. This appears to result from a crack-retarding influence of transverse fissuring associated with inclusion stringers in the carbon steel plate. The specific values of crack aspect ratio for these tests are listed in Table 4; in both materials the final aspect ratio appears to be independent of strain level.

Comparison of crack growth rate as a function of total strain range for both the bending and tension-compression tests of the carbon steel is shown in Figure 28. Since the strain range in the bend tests is an initial value only and may not remain constant throughout the test, it is somewhat questionable whether these results should be compared with the through-cracked plates for which strain range was controlled. The comparisons of Figures 28 and 29 indicate that the slope of the curve for the bend specimens is slightly less than that for the axial tests. However, the level of crack growth rate for the bending mode is much less than that for the center-slotted tension-compression plates. Since the rates for the 2-1/4 $\mathrm{Cr}-1 \mathrm{Mo}$ alloy were not constant but increased slightly with increasing crack length, the results for this steel are shown as a range of values (Figure 29). Figure 29 shows that their general magnitude is much less than those measured in tension-compression. 
Table 4

CRACK ASPECT RATIO IN BEND SPECIMENS

AT ROOM TEMPERATURE

A-212B

$\begin{array}{cc}\begin{array}{c}\text { Strain } \\ \text { Level (\%) }\end{array} & \begin{array}{c}\text { Final Crack } \\ \text { Depth (in.) }\end{array} \\ \pm 0.3 & 0.17 \\ \pm 0.5 & 0.19 \\ \pm 1.0 & 0.21\end{array}$

Final Surface

Crack Length (in.)

1.99

1.90

2.18
Final Crack

Length-to-Depth Ratio, 2c/a

11.1

10.0

10.9

2-1/4 Cr-1 Mo

$\begin{array}{llll} \pm 0.3 & 0.27 & 2.11 & 7.5 \\ \pm 0.5 & 0.28 & 2.03 & 7.6 \\ \pm 1.0 & 0.33 & 2.00 & 6.4\end{array}$

\section{Crack Length-to-Depth Ratio for 2-1/4 Cr-1 Mo}

Alloy at $\pm 0.3 \%$ Strain Level

Surface
Crack Length
2c (in.)
0.25
0.80
1.63

2.11

Crack
Depth, a (in.)
0.06
0.14
0.24
0.28

$\begin{array}{cc}\begin{array}{c}\text { Crack } \\ \text { Length-to-Depth } \\ \text { Ratio, 2c/a }\end{array} & \\ 4.1 & \mathrm{a} / 2 \mathrm{c} \\ 5.65 & 0.244 \\ 6.8 & 0.177 \\ 7.5 & 0.147 \\ & 0.133\end{array}$

Comparison of the results of the bend tests of the $2-1 / 4 \mathrm{Cr}-1 \mathrm{Mo}$ and carbon steel with those for a carbon steel of comparable yield strength $^{3}$ is shown in Figure 30 . There is negligible difference between the 2-1/4 $\mathrm{Cr}-1 \mathrm{Mo}$ and the carbon steel of this study, or between this carbon steel and another of similar yield strength obtained under controlled constant strain rather than deflection. The good correspondence of the two groups of data suggests that the variable of constant deflection versus constant strain may not be a major one in controlling the general levels of crack growth rates in these specimens and steels.

In viow of the eignifioantly lower levels of erack gruwulli rate for the reverse loaded bend tests at room temperature, an attempt was made to compare these results with those for the axially loaded plates using the stress intensity factor approach. For this purpose, the analysis of Smith ${ }^{7}$ for a semielliptical surface cracked beam, was employed; i.e.,

$\mathrm{K}_{\mathrm{I}}=\mathrm{M}_{\mathrm{B}^{\sigma}} \sqrt{\pi} \sqrt{\mathrm{c} / \mathrm{Q}}$

(Reference 7)

where

$\mathrm{M}_{\mathrm{B}}=$ proportionality constant,

$\sigma \quad=\quad$ outer fiber bending stress, psi; equal to bending moment $\div$ section modulus,

c = crack depth (inches),

$2 \mathrm{a}=$ surface crack length (inches).

Q = shape factor,

$\mathrm{Q}=\phi^{2}-0.212\left(\sigma / \sigma_{\mathrm{ys}}\right)^{2}$.

(Referençè 7)

$\phi \quad \int_{0}^{\pi / 2}\left[1-\left(\frac{a^{2}-c^{2}}{a^{2}}\right) \sin ^{2} \phi\right]^{1 / 2} d \phi$.

(Reference 8) 
The characteristics of the above relationship are shown in Figure 31, which shows $M_{B}$ as a function of relative crack depth for various levels of $\mathrm{c} / 2 \mathrm{a}$. Details and results of the analysis are shown in Table 5. Although some interpolation of the curves in Figure 31 was required, the major uncertainty is in the value of $Q$ employed: Since the formulation for $Q$ (the shape factor) was originally derived for low stress fracture, and for $\sigma / \sigma_{\mathrm{ys}}$ ratios of unity or less, there is some question regarding its applicability to the $\sigma / \sigma \mathrm{ys}$ levels observed in these tests; i.e., 1.3 to 2.0. Consequently, $\mathrm{Q}$ values were calculated only for a $\sigma / \sigma_{\mathrm{ys}}$ of 1.0 .

The comparison of the bend test results with those for axial loading (Figure 16) are shown in Figure 32. This figure, which is identical to that of Figure 17 (with the deletion of some points for clarity), indicates within scatter, fairly consistent agreement between axially and bend-loaded, strain-controlled cyclic crack growth rates for the analysis scheme used.

\section{b. SUIVIMARY AND CONCLUSiONE}

Crack growth rates under reversed tension-compression, strain-controlled loading were measured for both the axial and bending case for A-212B carbon steel, 2-1/4 Cr-1 Mo, and Type 304 steels. Both through-cracked and part-through-cracked specimen configurations were employed for axial loading, and the part-through cracked case for bending tension-compression. From the results of these tests, the following conclusions were drawn:

1. Crack growth rates in through-cracked plate specimens tested in strain-controlled, reversed tension-compression are independent of crack length and are an exponential function of strain range with no apparent effect of thirkness in the range of 0.25 to 0.8 inch.

2. Crack growth rates in part-through, surface-cracked plates loaded in tension-compression are, prior to penetration, less than those for through-cracked plates at the same nominal strain range and are an apparent function of geometry. This report suggests a procedure for correlating these yeunetry effects.

3. Crack growth rates at room temperature in part-through, surface-cracked plates loaded in bending tension-compression are considerably less than those in a through-cracked axially loaded plate specimen. For a given strain range, crack growth rates in the bend specimens appear to be less at $550^{\circ} \mathrm{F}$ than those at room temperature. However, these results are meager and require verification.

4. Comparison of results of both axial and bending stralnecuntiulted lésts with thusc obtainod provinusly uninar stress-controlled conditions indicates good correlation on the basis of stress intensity factor range, $\Delta K$, derived from currently available fracture mechanics concepts. 
Table 5

ANALYSIS OF PTC CANTILEVER BEND TESTS

OF 2-1/4 Cr-1 Mo STEEL

A. Typical Crack Front Contours and Calculations

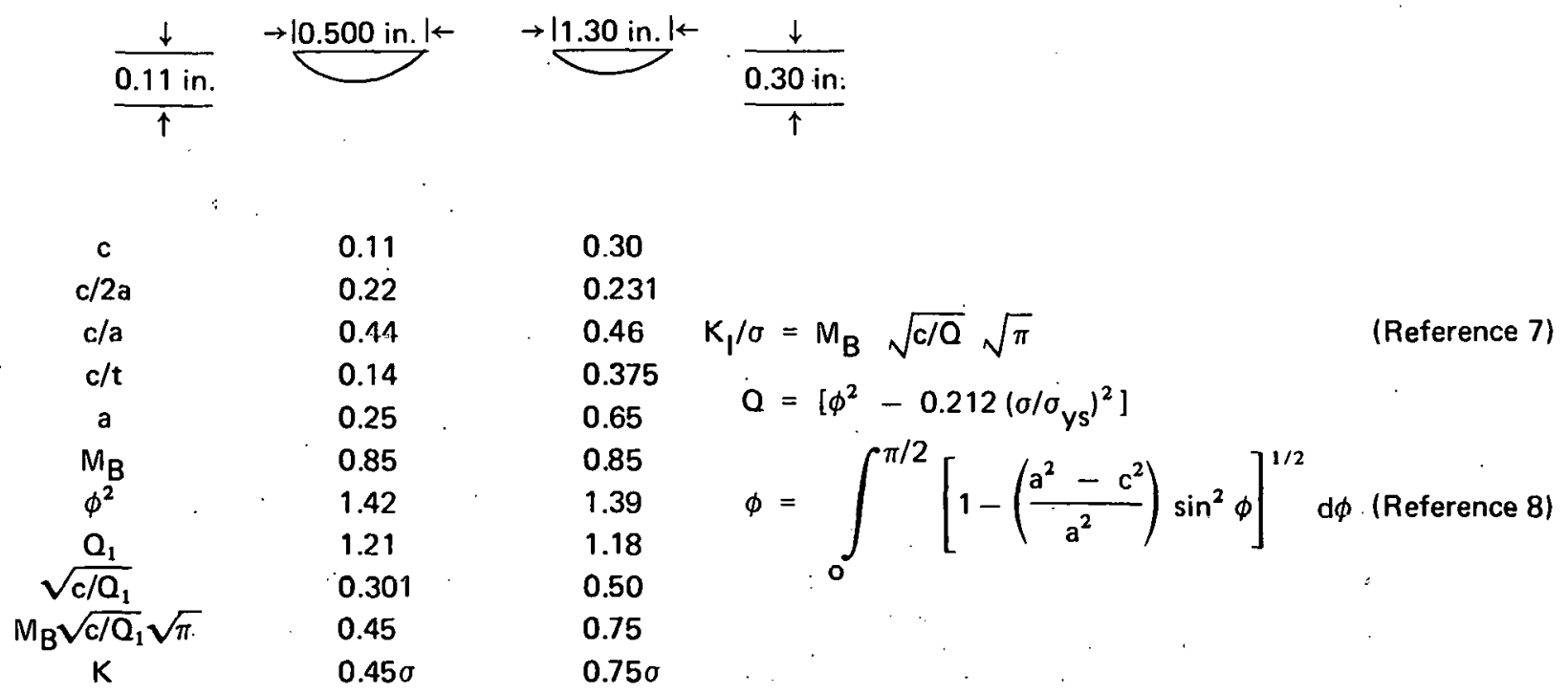

B. Results for $2-1 / 4 \mathrm{Cr}-1$ Mo Steel

\section{Total \\ Strain}

Range

$(\%)$

$\pm 0.3$

$\pm 0.5$

$\pm 0.7$

$\pm 1.0$

Crack
Length

$2 a$, inches

0.50

1.30

0.50

1.30

0.50

1.30

0.50

1.30

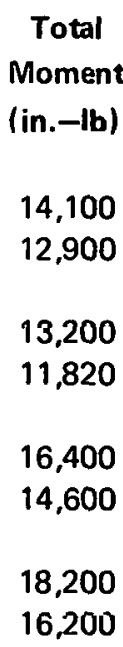

$\begin{gathered}\text { Total Range } \\ \text { of Stress } \\ \text { (psi) }\end{gathered}$
135,500
124,000
127,000
114,000
157,500
141,000
175,000
156,000

$\begin{array}{cc}\begin{array}{c}\text { Stress Intensity } \\ \text { Factor Range }\end{array} & \begin{array}{c}\text { da/dN } \\ \mu-\text { in./cycle }\end{array} \\ \Delta K, \text { psi } \sqrt{\text { in. }} & \\ & 0.00009 \\ 93,000 & 0.00015 \\ 93,300 & 0.00018 \\ & 0.0003 \\ 87,000 & 0.000445 \\ 85,700 & 0.00071 \\ 108,000 & 0.001 \\ 106,000 & 0.002 \\ 120,000 & \\ 117,500 & \end{array}$




\section{SECTION 6}

\section{ILLUSTRATIONS}

This section contains illustrations 1 through 32.

Figure

Title

Microstructural Features of Plate Steels . . . . . . . . . . . . . . . . . . . . 15

Configuration of Crack Growth Specimens . . . . . . . . . . . . . . . . . . . . . 16

Crack Growth Curves for A212B Steel at Room Temperature . . . . . . . . . . . . 17

Crack Growth Curves for 2-1/4 Cr-1 Mo Steel at Room Temperature . . . . . . . . . 18

Crack Growth Curves for Type-304 Steel at Room Temperature . . . . . . . . . . . . . . 19

Crack Growth Curves for 0.25-Inch-Thick 2-1/4 $\mathrm{Cr}-1$ Mo at Room Temperature,

Strain Range $= \pm 0.4 \%$. . . . . . . . . . . . . . . . . . . . . . . . . . . 20

7 Teiision Load ac a Functinn nf Crack Lenqth in Tension-Compression

Through-Lracked Plates . . . . . . . . . . . . . . . . . . . 21

8 Typical Fracture Appeảrance ur Axidlly-Loadcd Plato Specimens $\quad$. . . . . . . . . . . . . . . . 22

9 Surface Crack Growth Curves for PTC Specimens and Through-Crack Plates of $2-1 / 4 \mathrm{Cr}-1 \mathrm{Mn}$ lested at $\pm 0.2 \%$ Total Strain at RT . . . . . . . . . . . . 23

10 Loads as a Function of Cycles for PTC Specimens of 2-1/4 $\mathrm{Cr}-1 \mathrm{Mo}$ Steel Tested at $\pm 0.2 \%$ Total Strain Range . . . . . . . . . . . . . . . . . . . . . . . . 24

Comparison of Surface and Depth Crack Growth Curves for Part-Through Crack

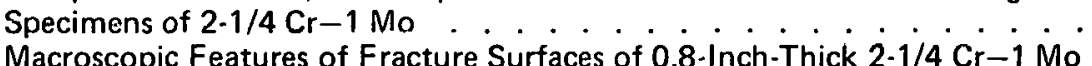

Specimens Cycled $\pm 0.2 \%$ at Room Temperature . . . . . . . . . . . .

Fracture Appearance of PTC Specimens of 0.8-Inch-Thick 2-1/4 Cr-1 Mo Cycled

Correlation of Crack Growth Rate and Total Strain Range for $2-1 / 4 \mathrm{Cr}-1$ Mo

Crack Growth at Room Temperature as a Function of Total Strain Range

for A-212B Carbon Steel

Crack Growth at Room Temperature as a Function of Total Strain Range for

Type-304 Stainless Steel .. . . . . . . . . . . . . . . . . . . .

Crack Growth Correlation for 2-1/4 $\mathrm{Cr}-1$ Mo Alloy with Various Loading

Sr.hemes for Both 5.0-Inch- and 14.0-Inch-Wide Specimens

Change in Crack Length, Load, and Stress Intensity Factor for a Through-Crack

Plate. Specimen as a Function of Number of Cycles for Type-304 Stainless

Steel, Strain Range $=0.4 \%$

Correlation Between Measured and Predicted Crack Growth Rates in PTC Specimens

of 2-1/4 Cr-1 Mo Steel Tested at Total Strain Range of $0.4 \%$ At Room Temperature

Crack Growth Curves for A-212B Carbon Steel at Room Temperature in

Reversed Bend-Loaded Beams

Crack Growth Curves

Bend-Loaded Beams

for 2-1/4 Cr-1 Mo Steel at Room Temperature in Reversed

Crack Growth Curves for Reverse-Loaded Bend Beams of $A-212 B$ at $550^{\circ} \mathrm{F} \quad . \quad . \quad . \quad . \quad$.

Crack Growth Curves for Reverse-Loaded Beams of $2-1 / 4 \mathrm{Cr}-1 \mathrm{Mo}$ at $550^{\circ} \mathrm{F}$. . . . . . . . . . .

Crack Length and Applied Moments as a Function of Cycles for A-212B at Room

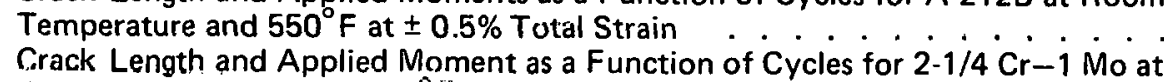

Room Temperature and $550^{\circ} \mathrm{F}$ at $\pm 0.5 \%$ Total Strain . . . . . . . . . . .

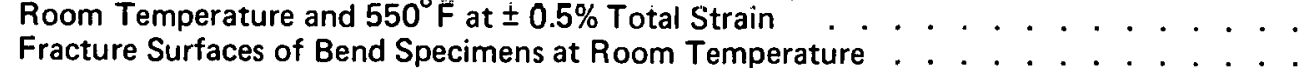

Fracture Surfaces of Bend Specimens at $550^{\circ} \mathrm{F}$

Comparison of Tension-Compression versus Bend Loading on Correlation of Crack

Growth Rate and Total Strain Range for A-212B Steel at Room Temperature

Comparison of Tonsion-Compression versus. Rend Loading on Correlation of Crack

Growth Rate and Total Strain Range for 2-1/4 Cr-1 Mo Allow at Room Temperature . .

Comparison of 2-1/4 Cr-1 Mo and A-212B with A-201 Steel (Ref. 3) Tested as

Surface-Cracked Cantilever Beams . . . $\cdot 0^{\circ} \cdot \dot{0}^{\circ} \cdot 90^{\circ}$ 

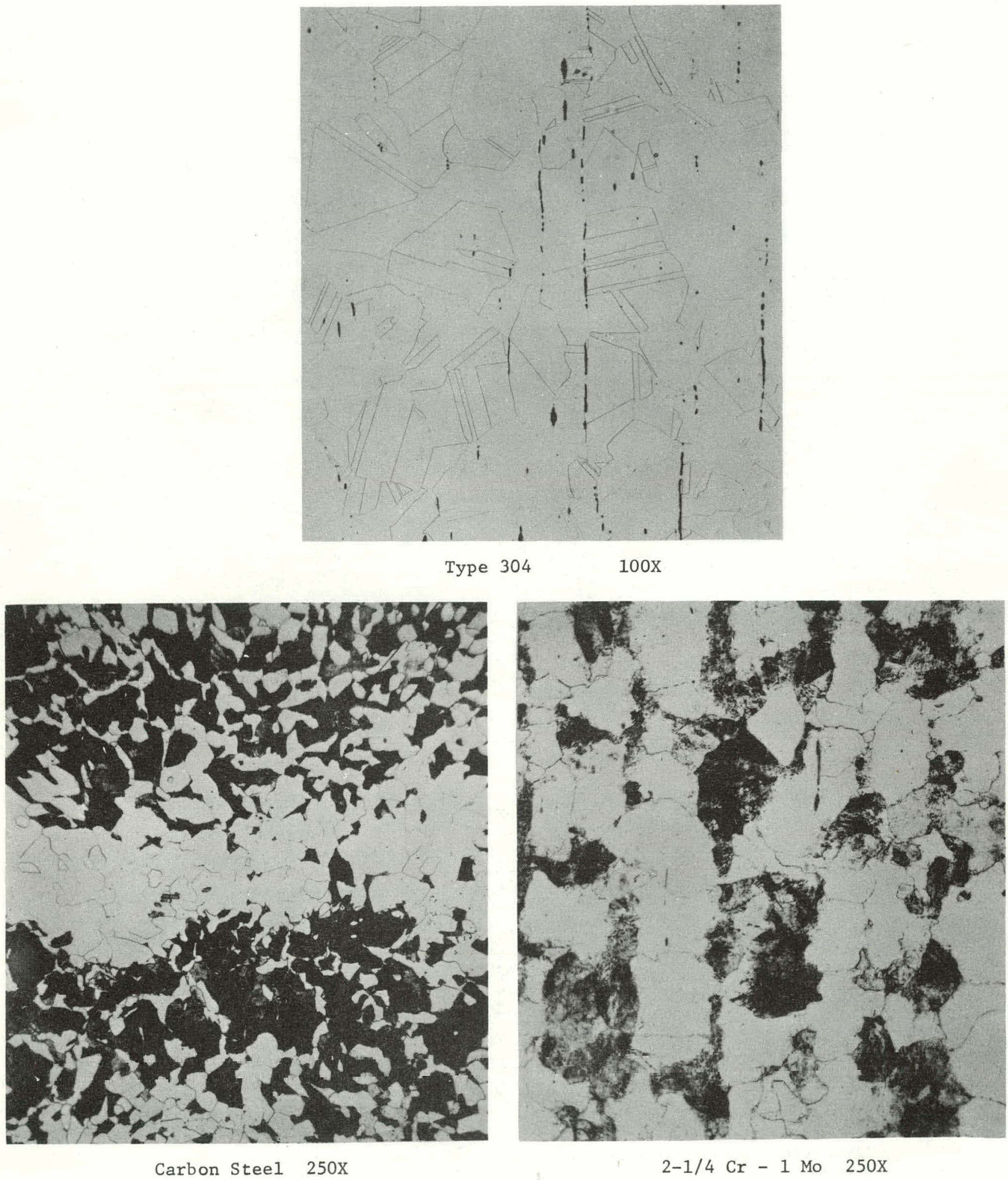

Figure 1. Microstructural Features of Plate Steels 


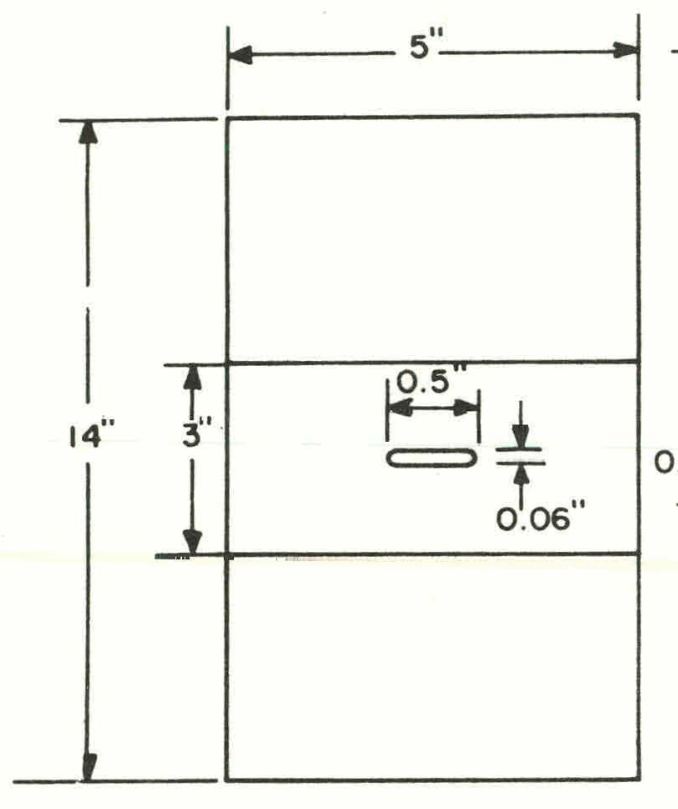

(A) Through crack plate spec.

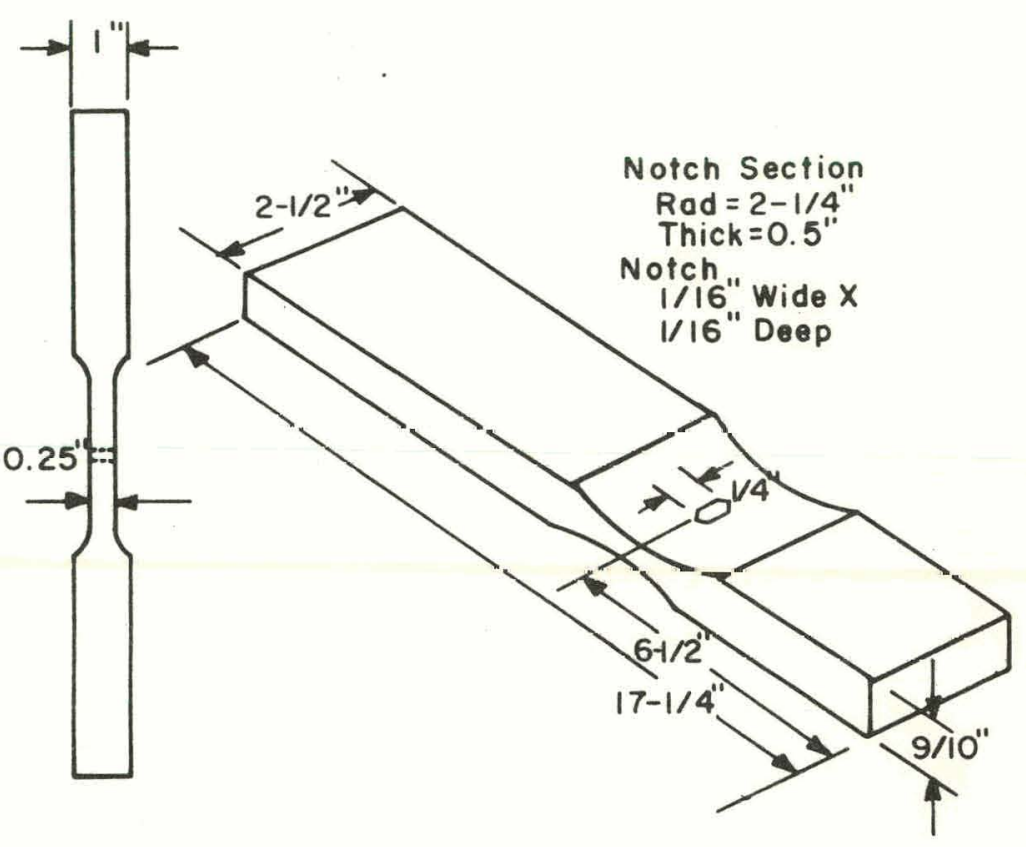

(C) Cantilever bend spec.
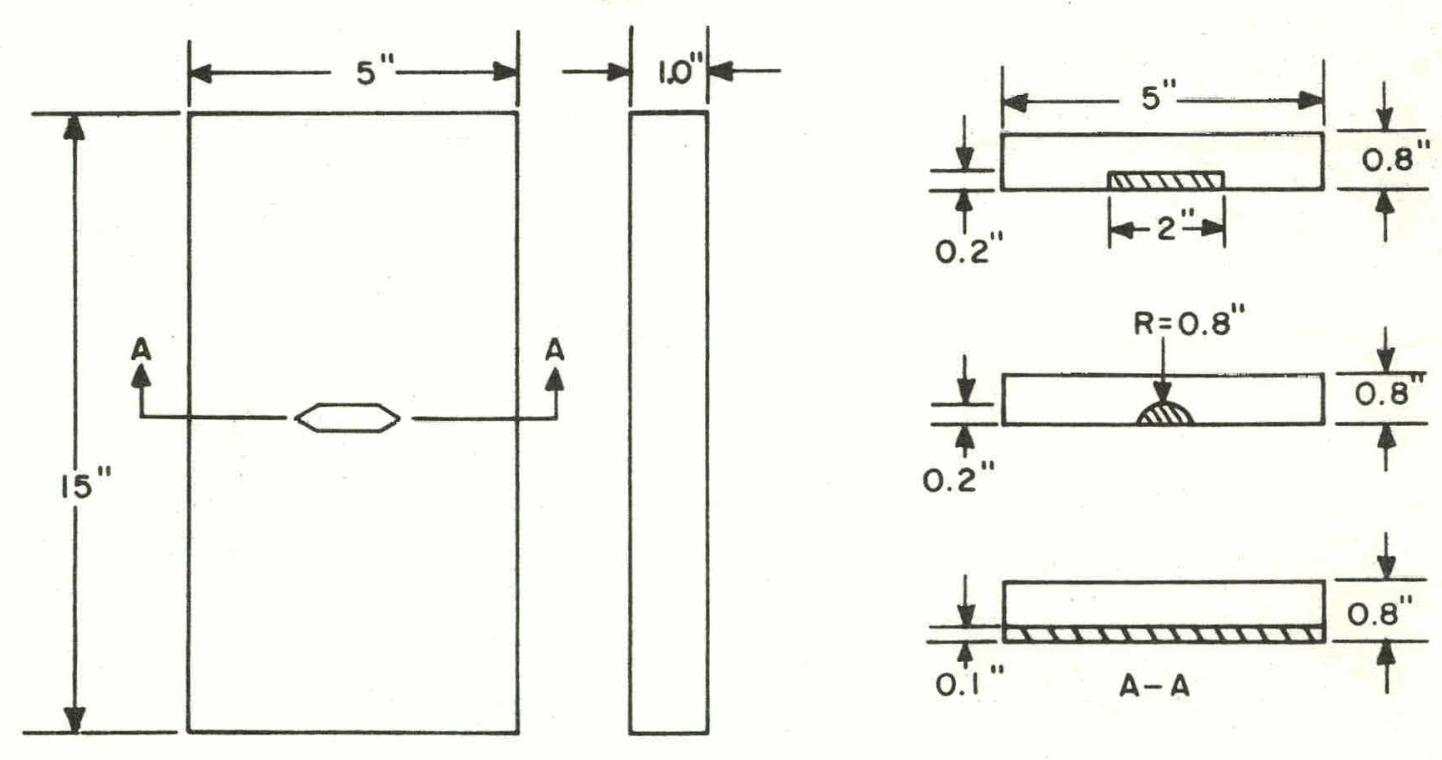

(B) Part-through crack spec.

Figure 2. Configuration of Crack Growth Specimens 


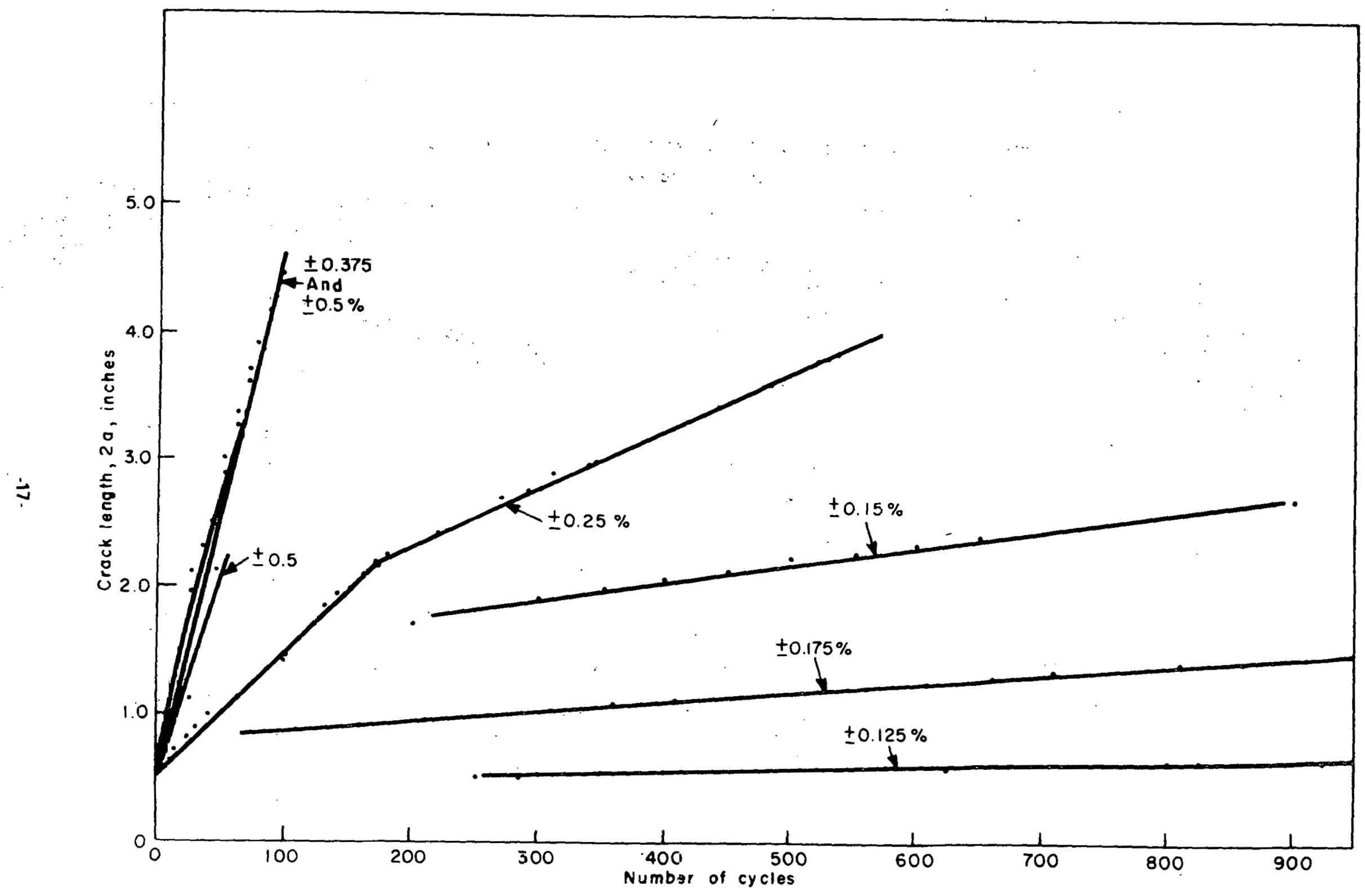


$\dot{\vec{\infty}}$

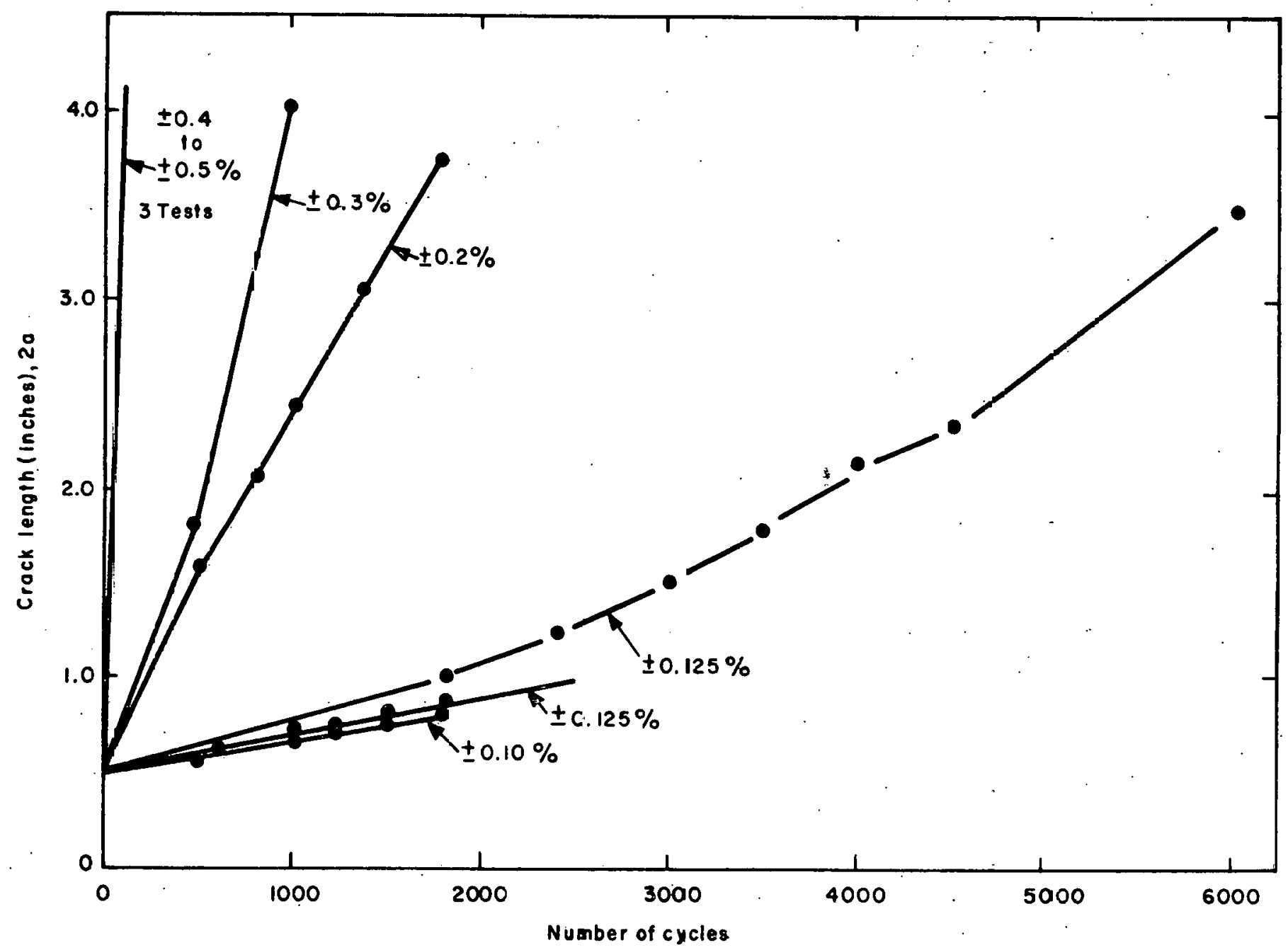

Figure 4. Crack Growth Curves for 2-1/4 Cr-1Mo Steel at Room Temperature 


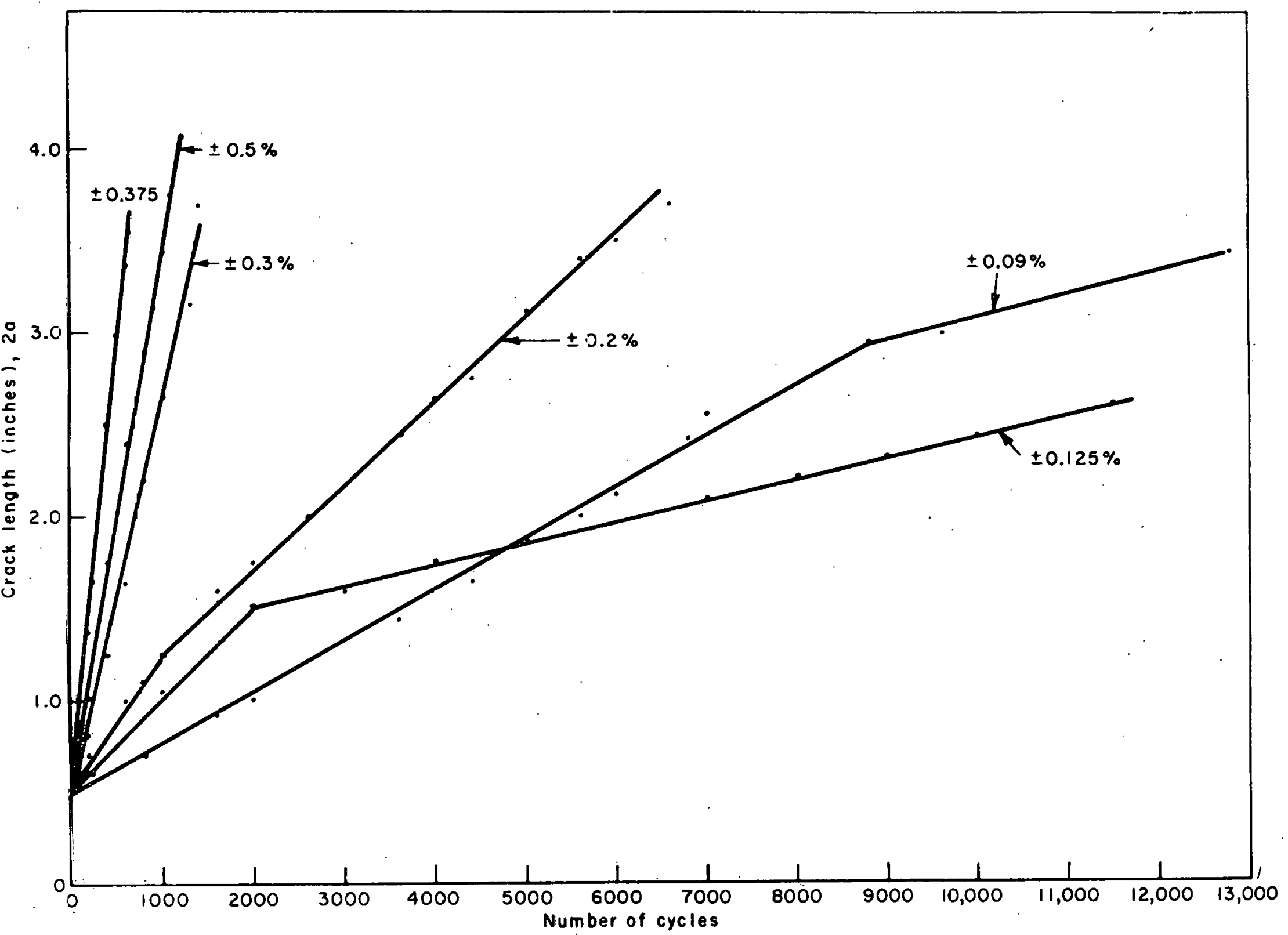

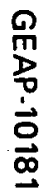

Figure 5. Crack Growth Curves for Type-304 Steel at Room Temperature 


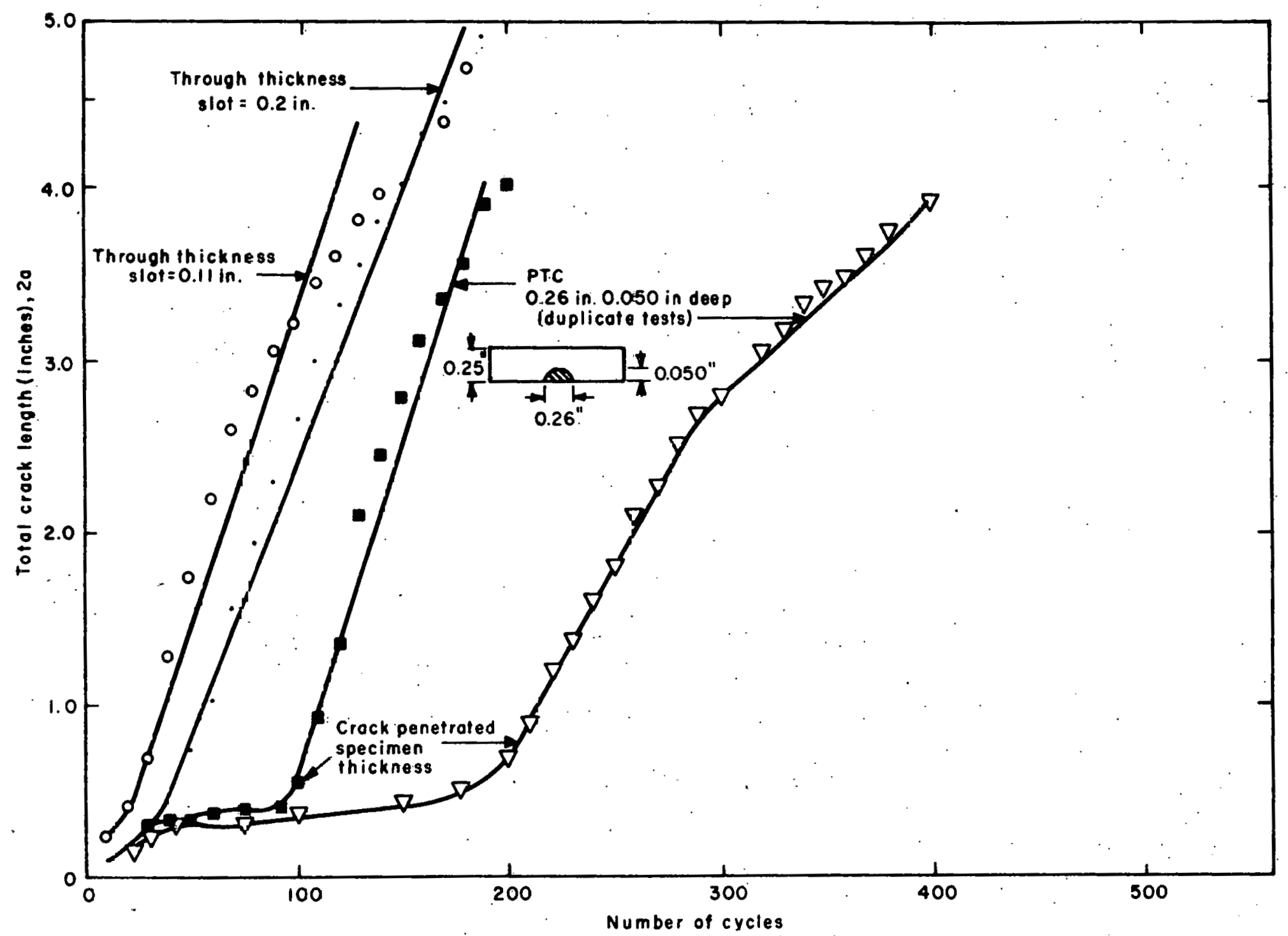

Figure 6. Crack Growth Curves for 0.25 -Inch-Thick 2-1/4 $\mathrm{Cr}-1 \mathrm{Mo}$ at Room Temperature, Strain Range $= \pm 0.4 \%$ 


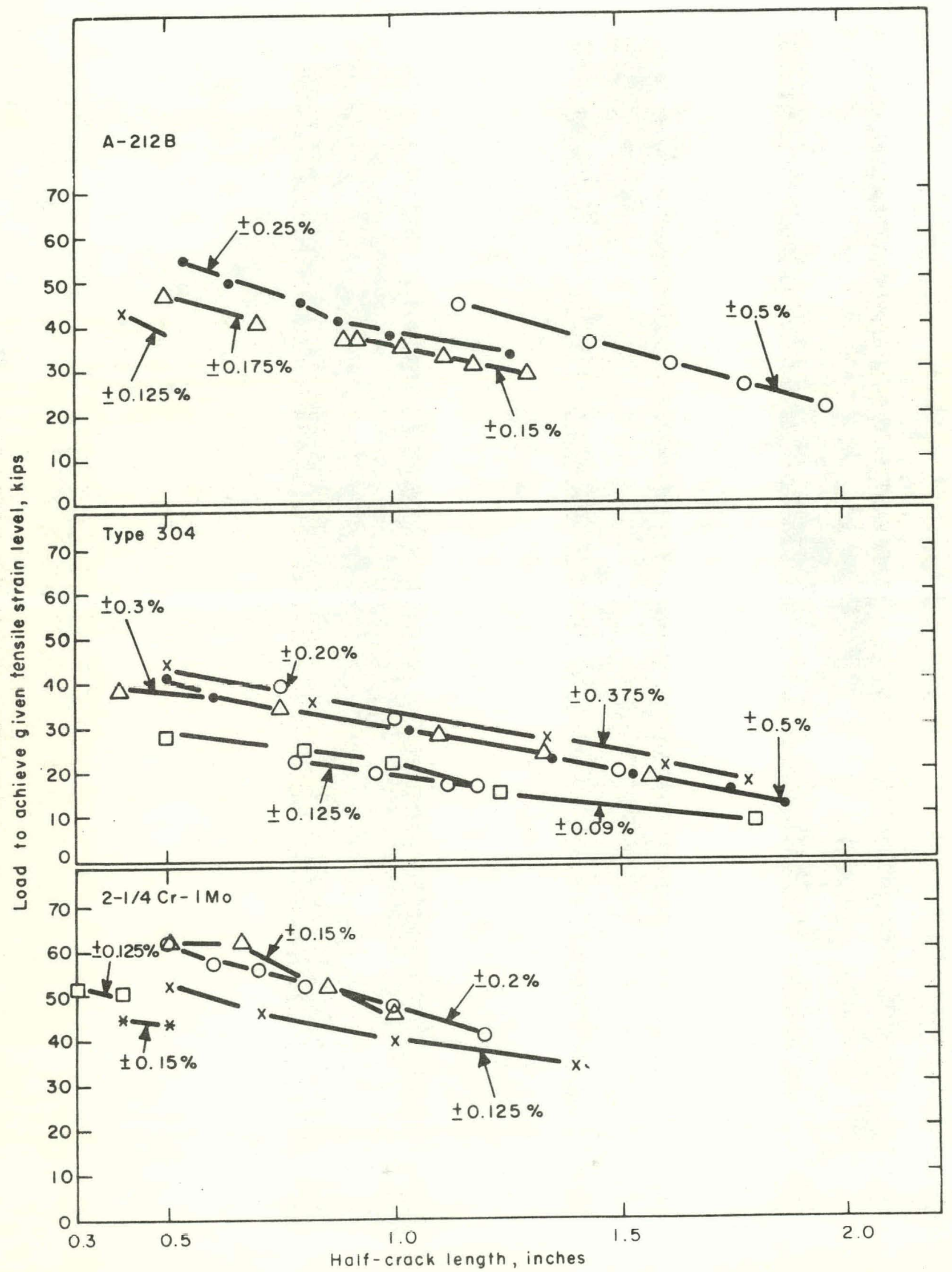

Figure 7. Tension Load as a Function of Crack Length in Tension-Compression Through-Cracked Plates 


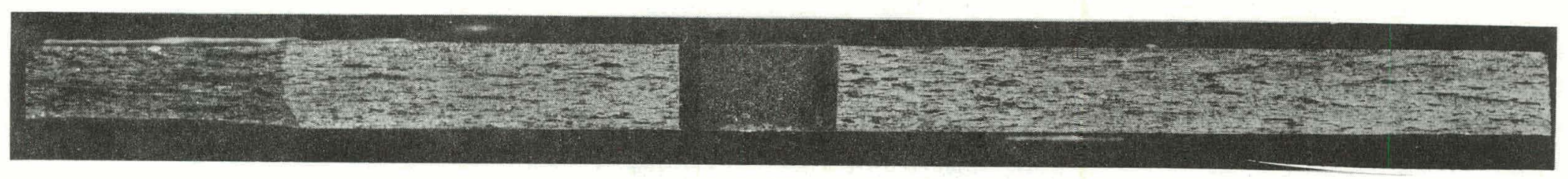

$A-212 B$

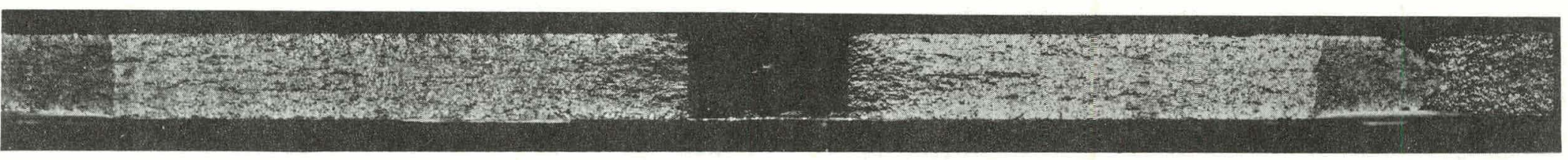

$21 / 4 \mathrm{Cr}-1 \mathrm{Mo}$

N

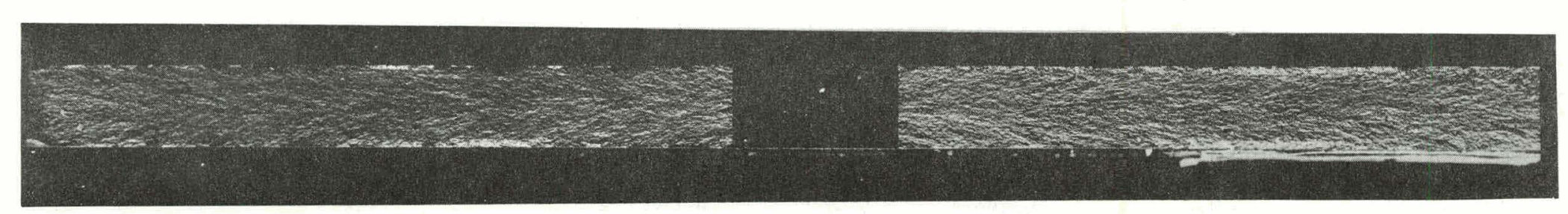

Type 304

Figure 8. Typical Fracture Appearance of Axially-Loaded Plate Specimen.s. 2X 


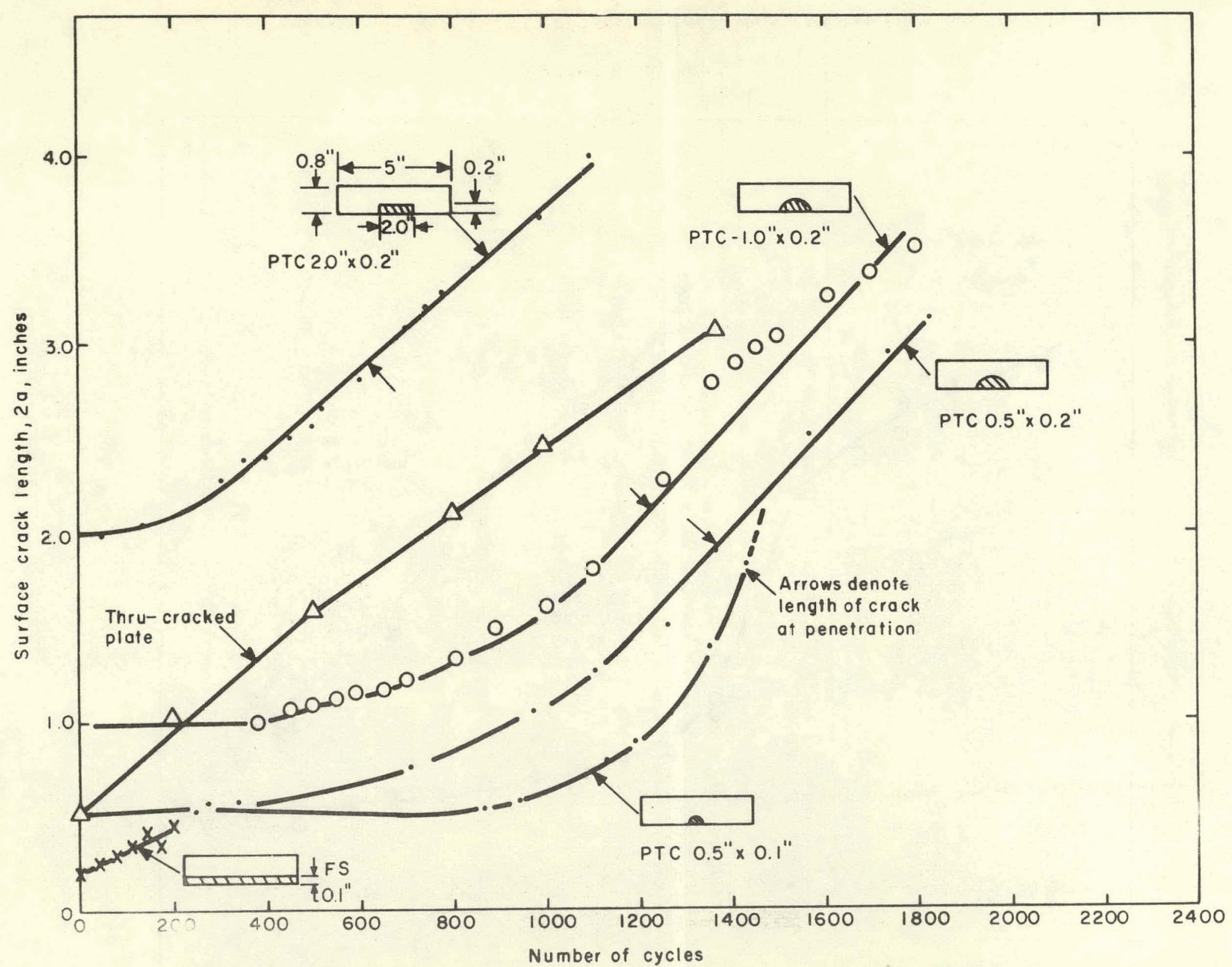

Figure 9. Surface Crack Growth Curves for PTC Specimens and Through-Crack Plates of 2-1/4 Cr-1 Mo Tested at $\pm 0.2 \%$ Total Strain at $R T$ 


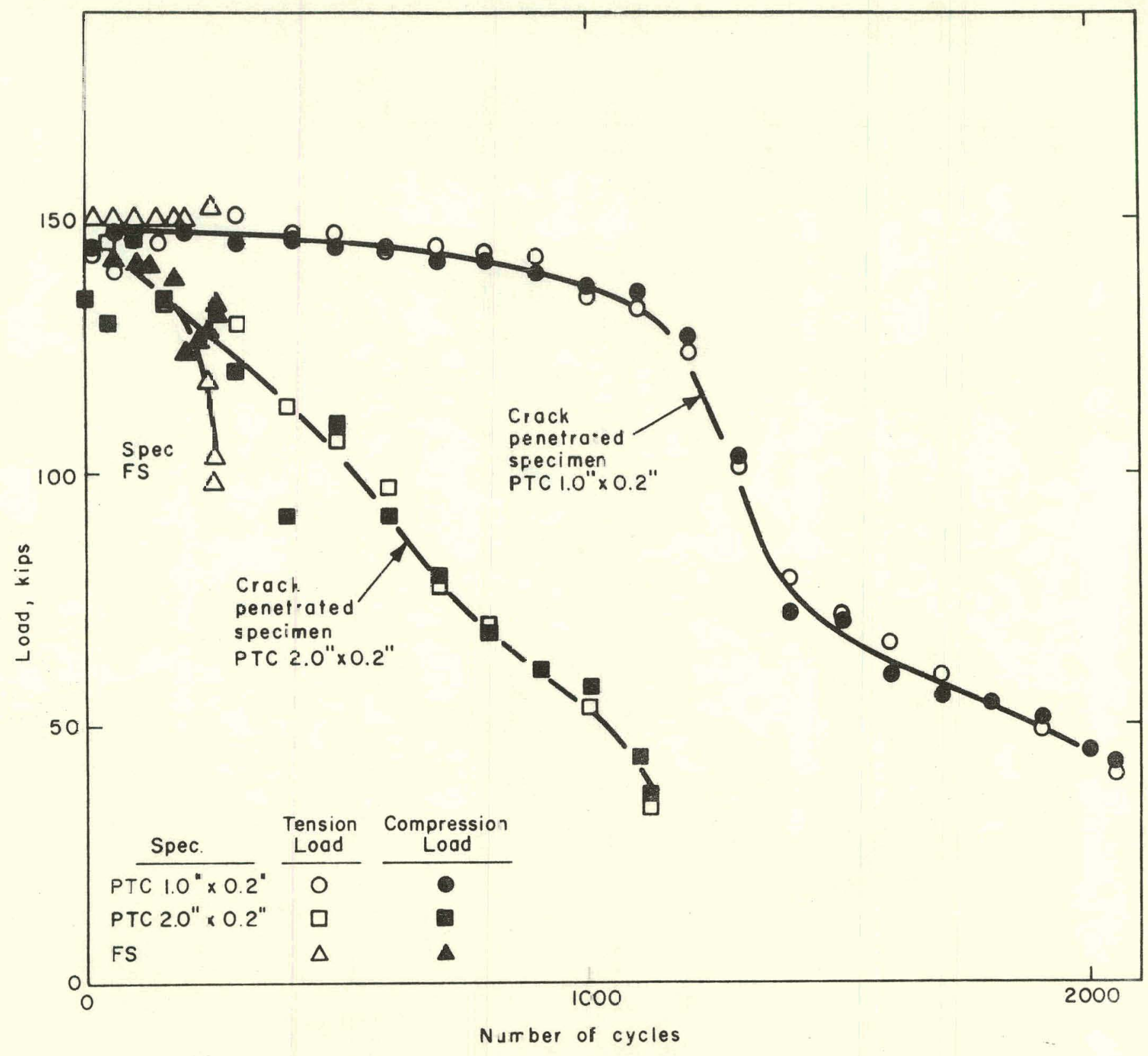

Figure 10. Load as a Function of Cycles for PTC Spesimens of 2-1/4 Cr-1 Mo Steel Tested at $\pm 0.2 \%$ Total Strain Range 


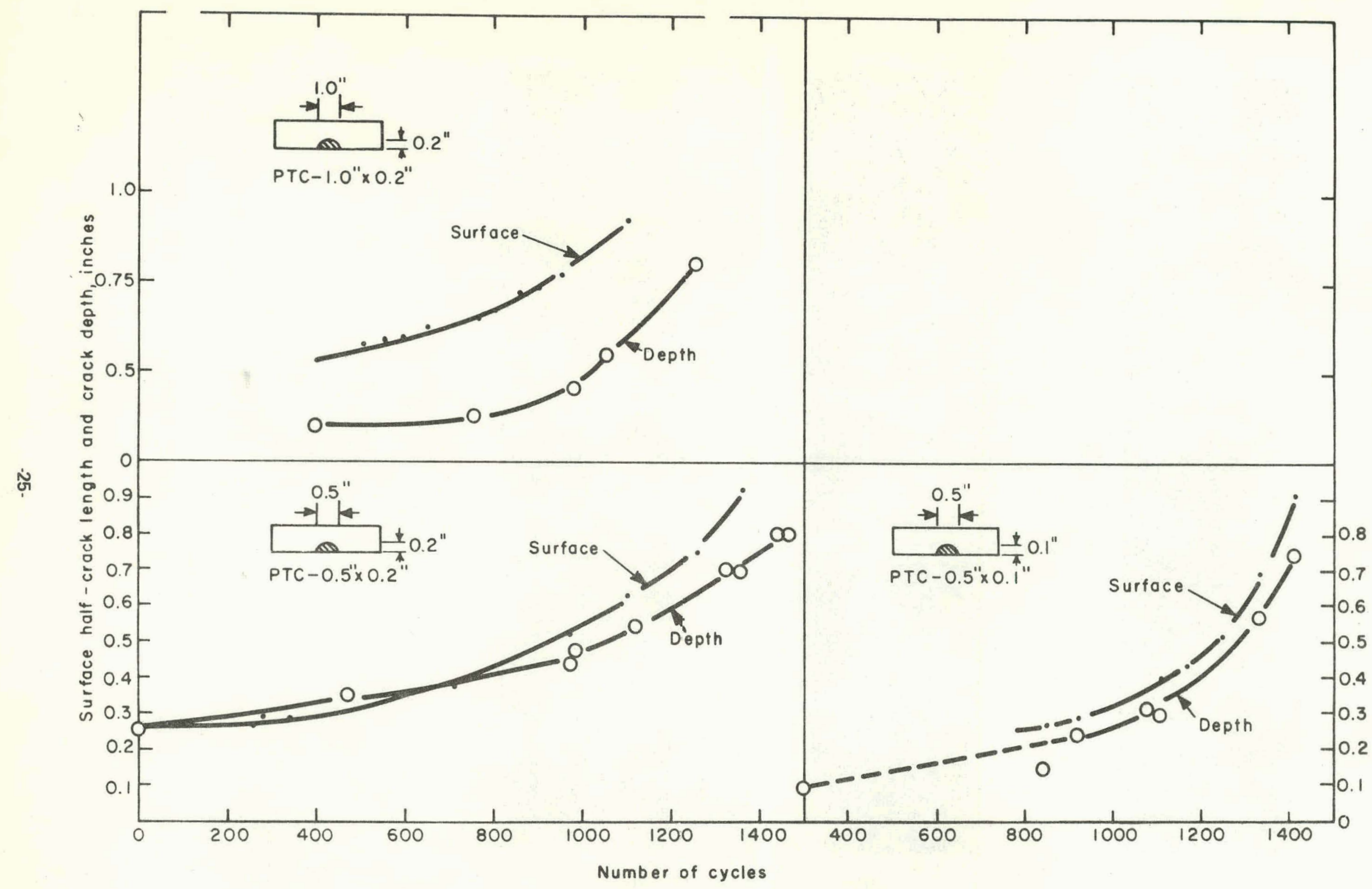




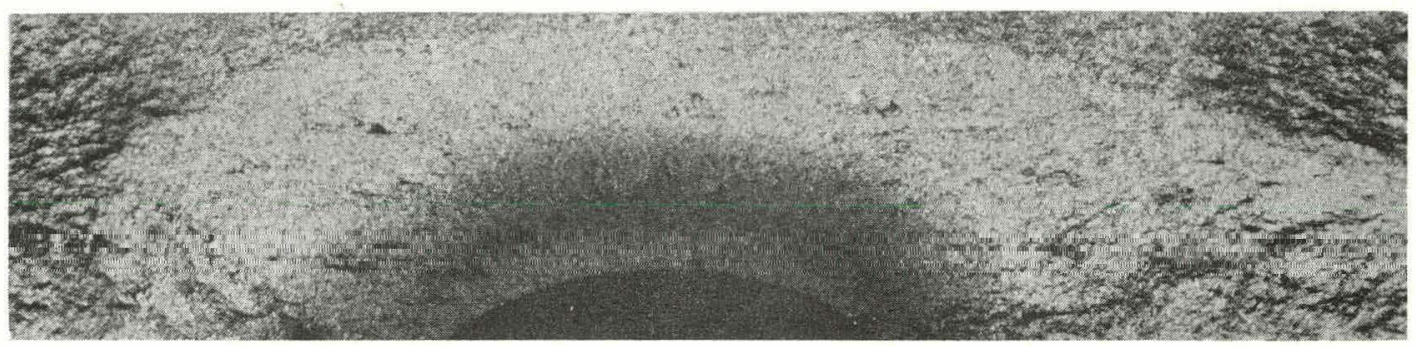

(a) PTC - 1" $\times 0.2^{\prime \prime}$

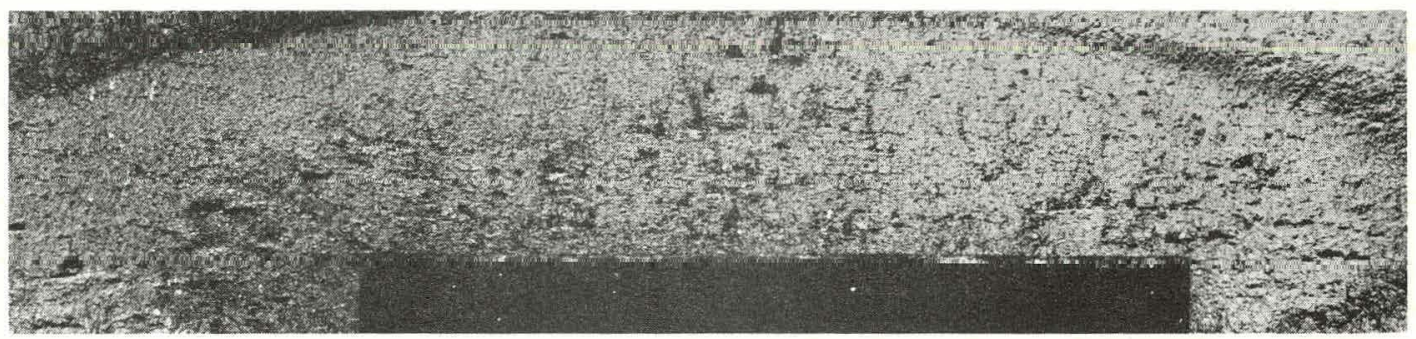

(b) PTC - 2" $\times 0.2^{\prime \prime}$

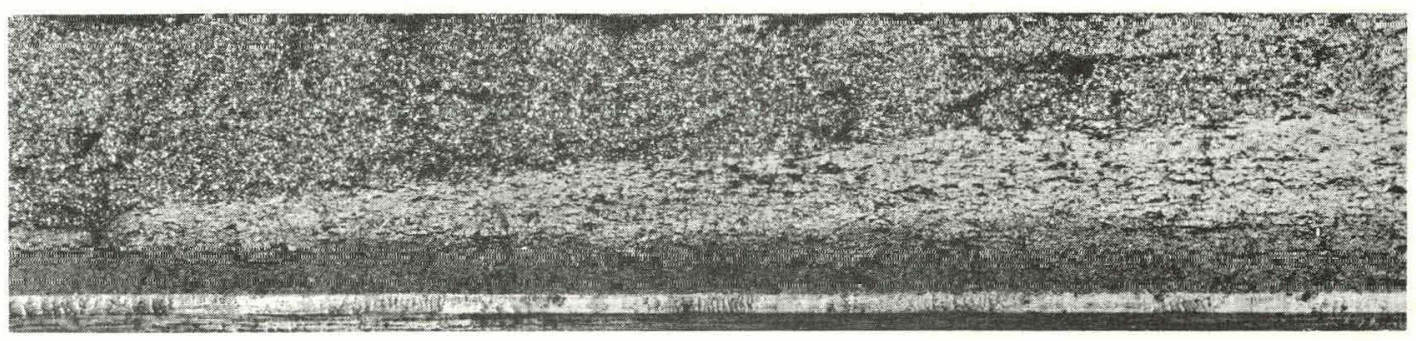

(c) FS - 5" $\times 0.1 "$

Figure 12. Macroscopic Features of Fracture Surfaces of 0.8-Inch-Thick 2-1/4 Cr-1 Mo Specimens Cycled $\pm 0.2 \%$ at Room Temperature $2 X$ 
GEAP-10181

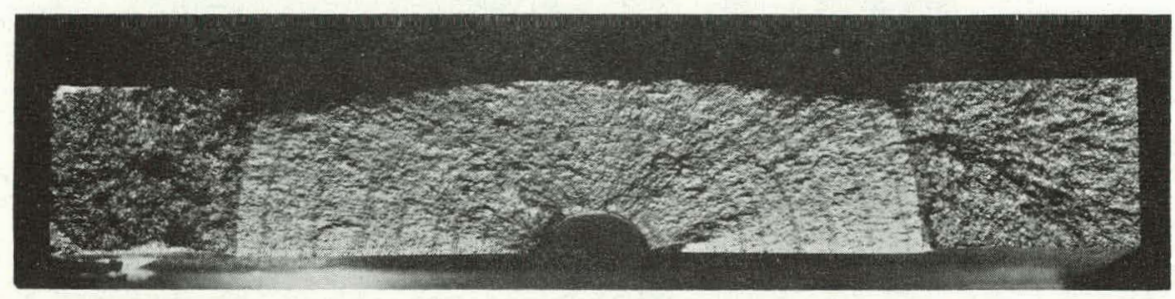

PTC $-0.5^{\prime \prime} \times 0.2^{\prime \prime}$

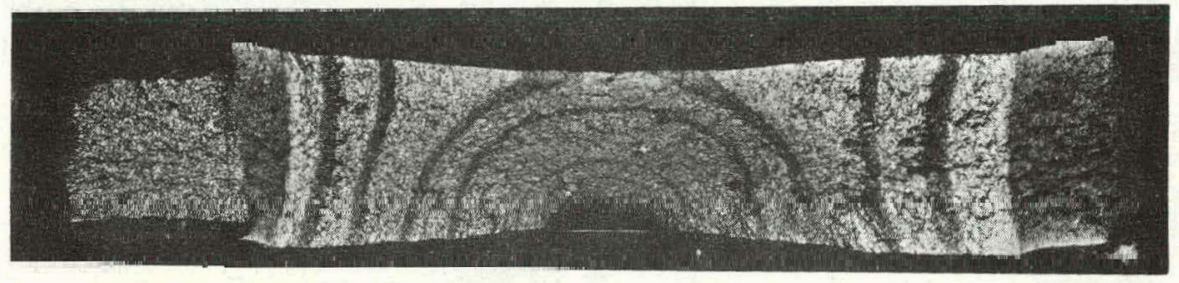

PTC - $0.5 " \times 0.1 "$

Figure 13. Fracture Appearance of PTC Specimens of 0.8 -Inch-Thick 2-1/4 Cr-1 Mo Cycled $\pm 0.2 \%$ at Room Temperature 


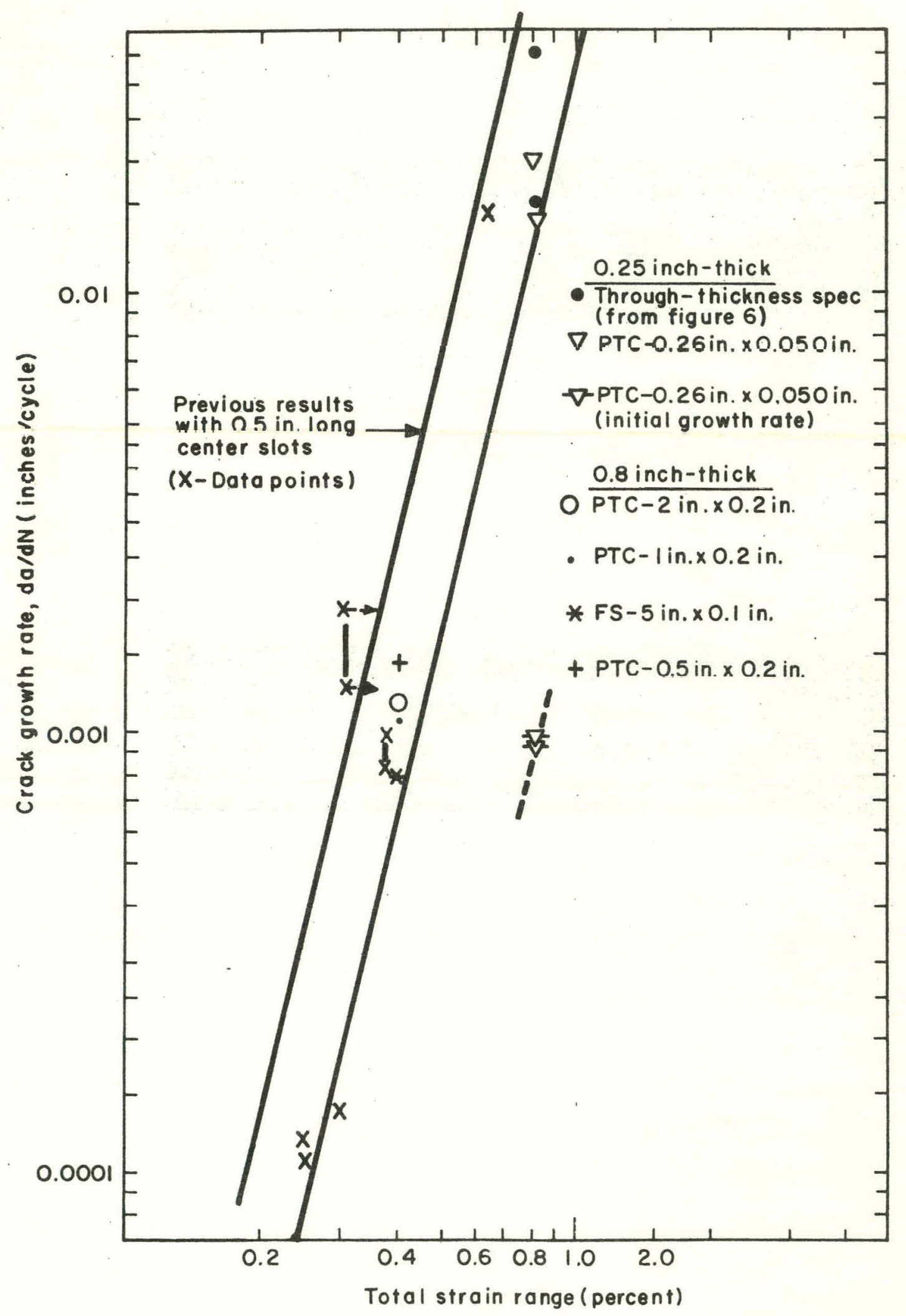

Figure 14. Correlation of Crack Growth Rate and Total Strain Range for 2-1/4 Cr-1 Mo Steel at Room Temperature 


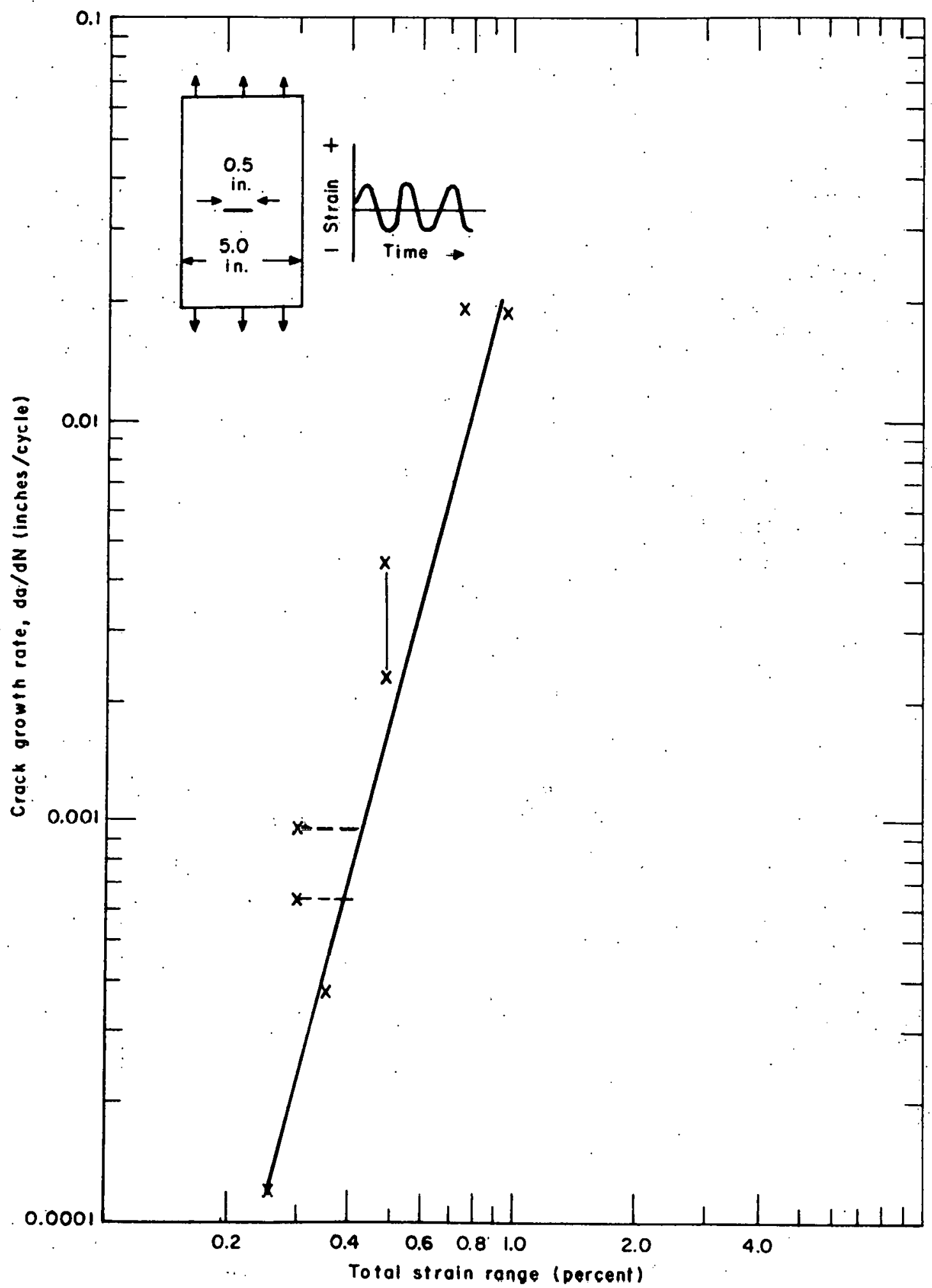

Figure 15. Crack Growth at Room Temperature as a Function of Total Strain Range for A-212B Carbon Steel 


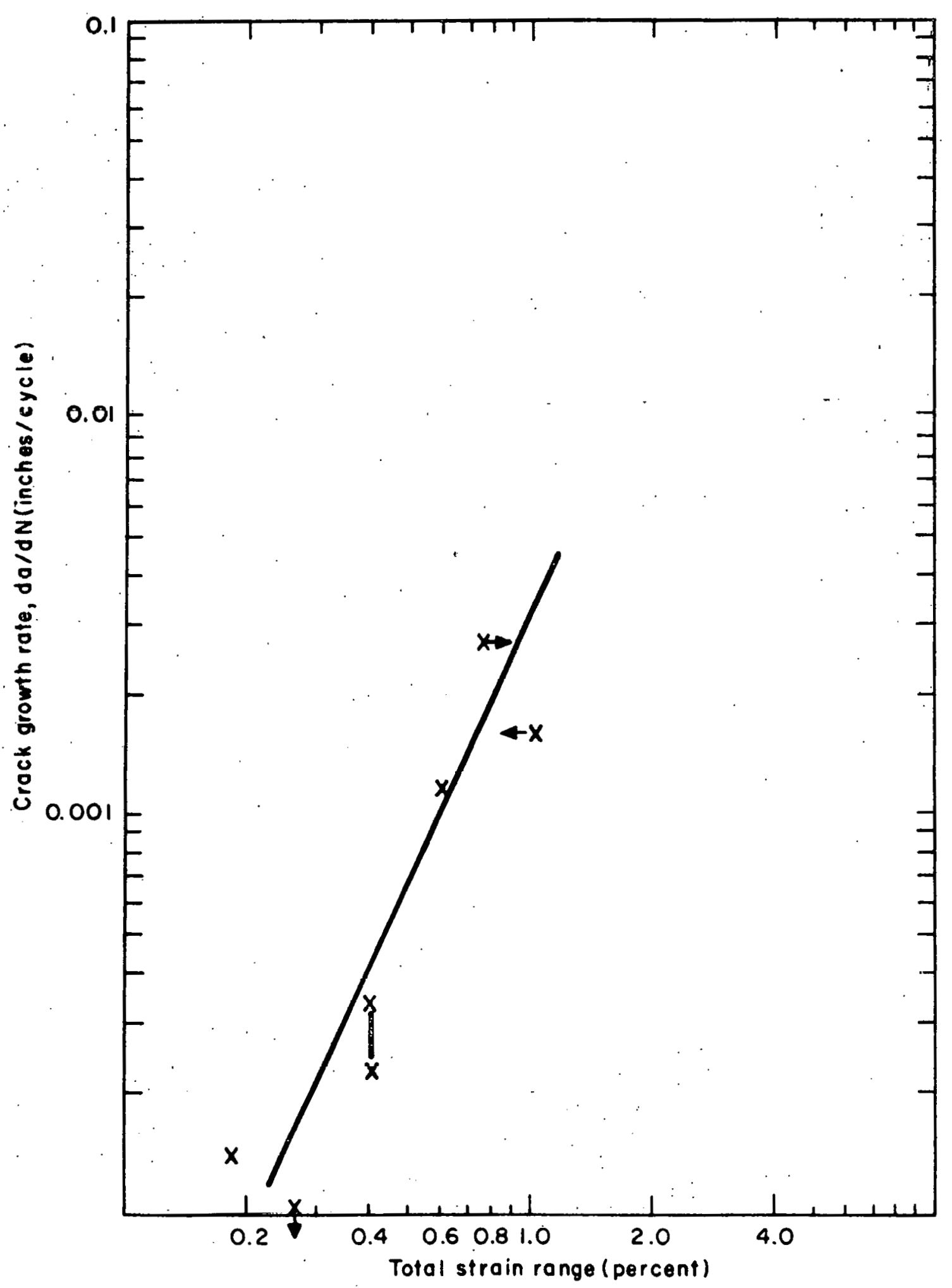

Figure 16. Crack Growth at Room Temperature as a Function of Total Strain Range for Type-304 Stainless Steel 
GEAP-10181.

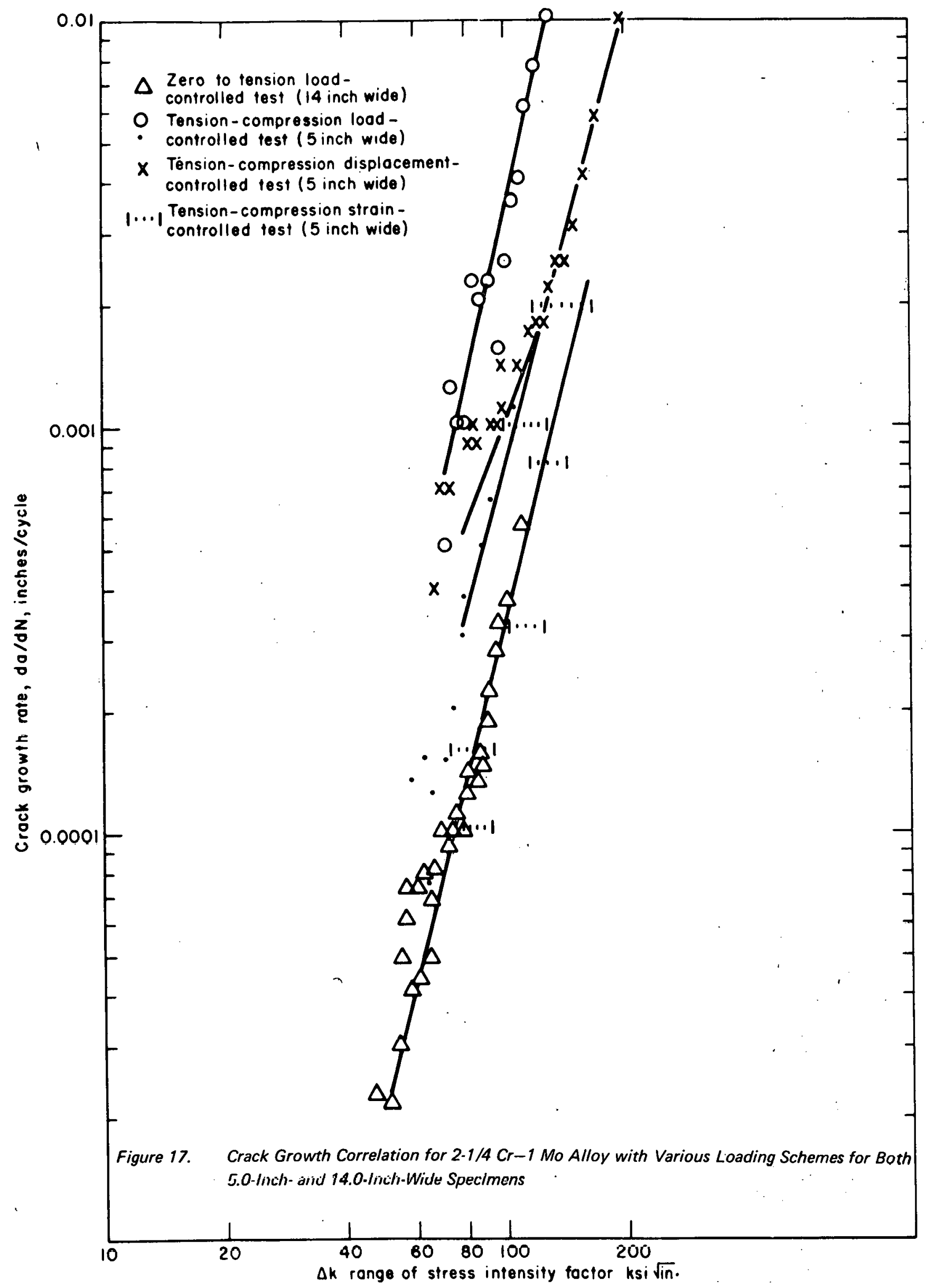




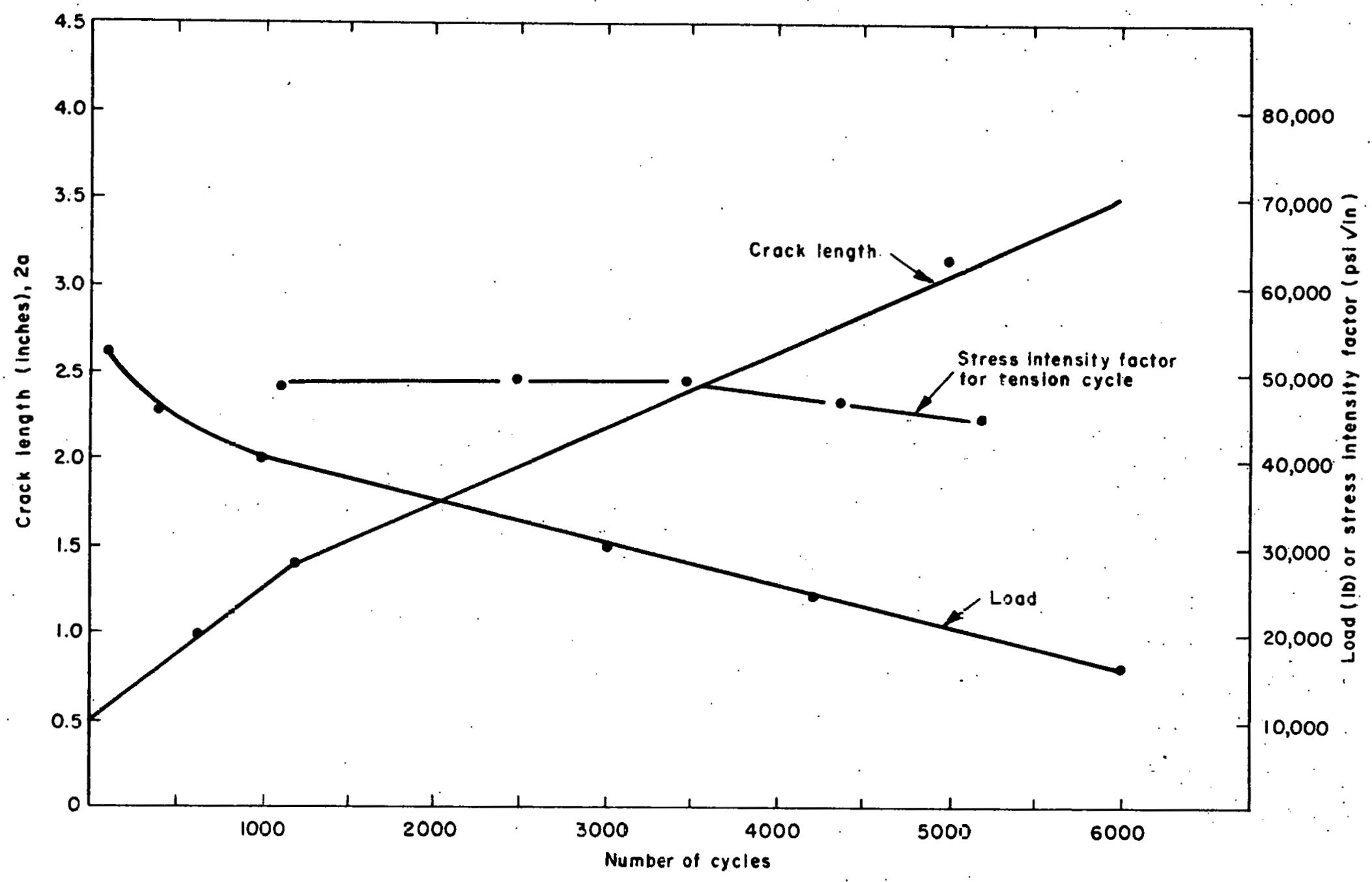

Figure j8. Change in Crack Length, Load, and Stress Intensity Factor for a Through. Crack Plate Specimen as a Function of Number of Cycles ior Type-304 Stainiess Steel, Strain Range $=0.4 \%$ 


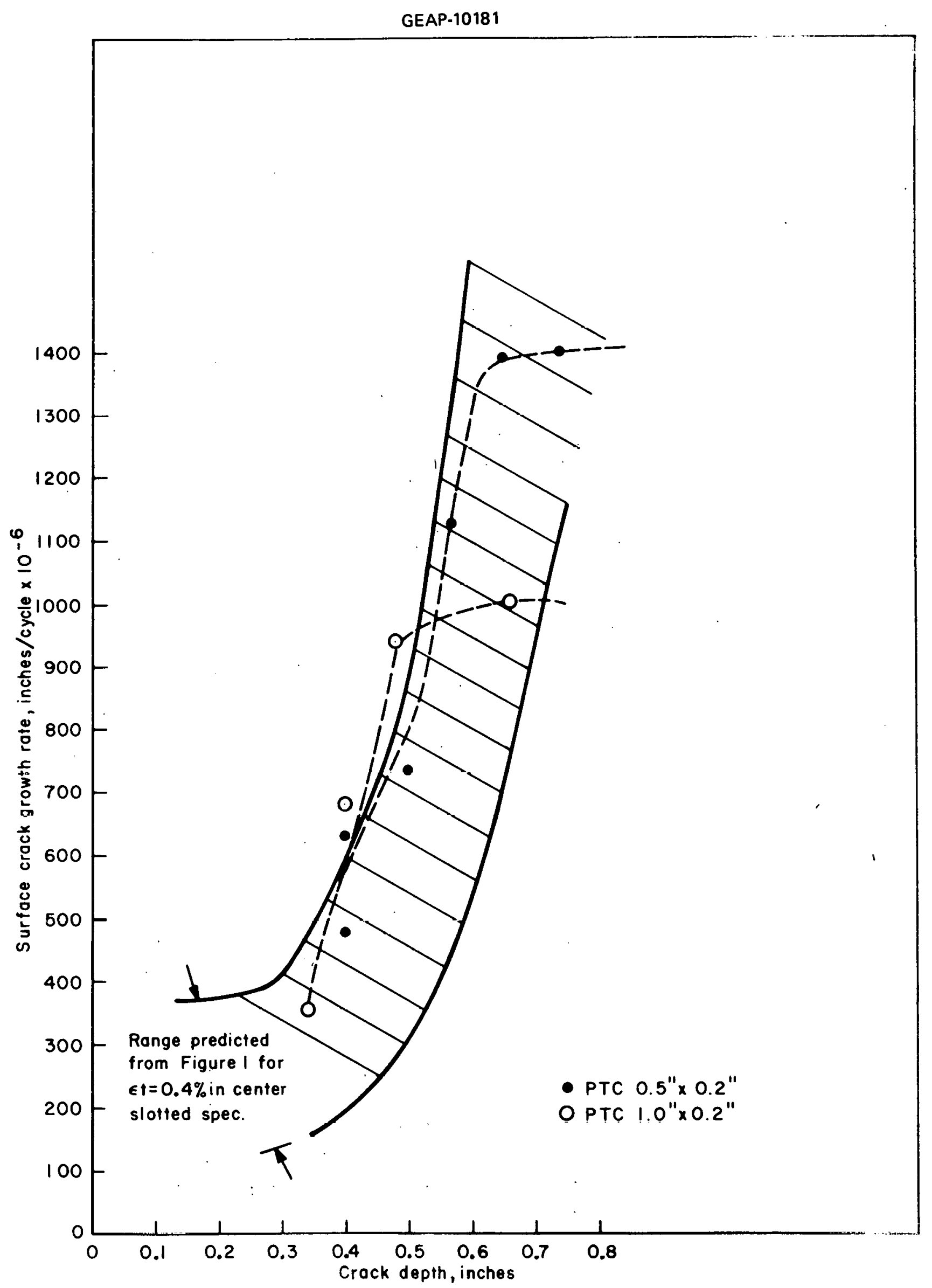

Figure 19. Correlation Between Measured and Predicted Crack Growth Rates in PTC Specimens of 2-1/4 Cr-1 Mo Steel Tested at Total Strain Range of $0.4 \%$ at Room Temperature 


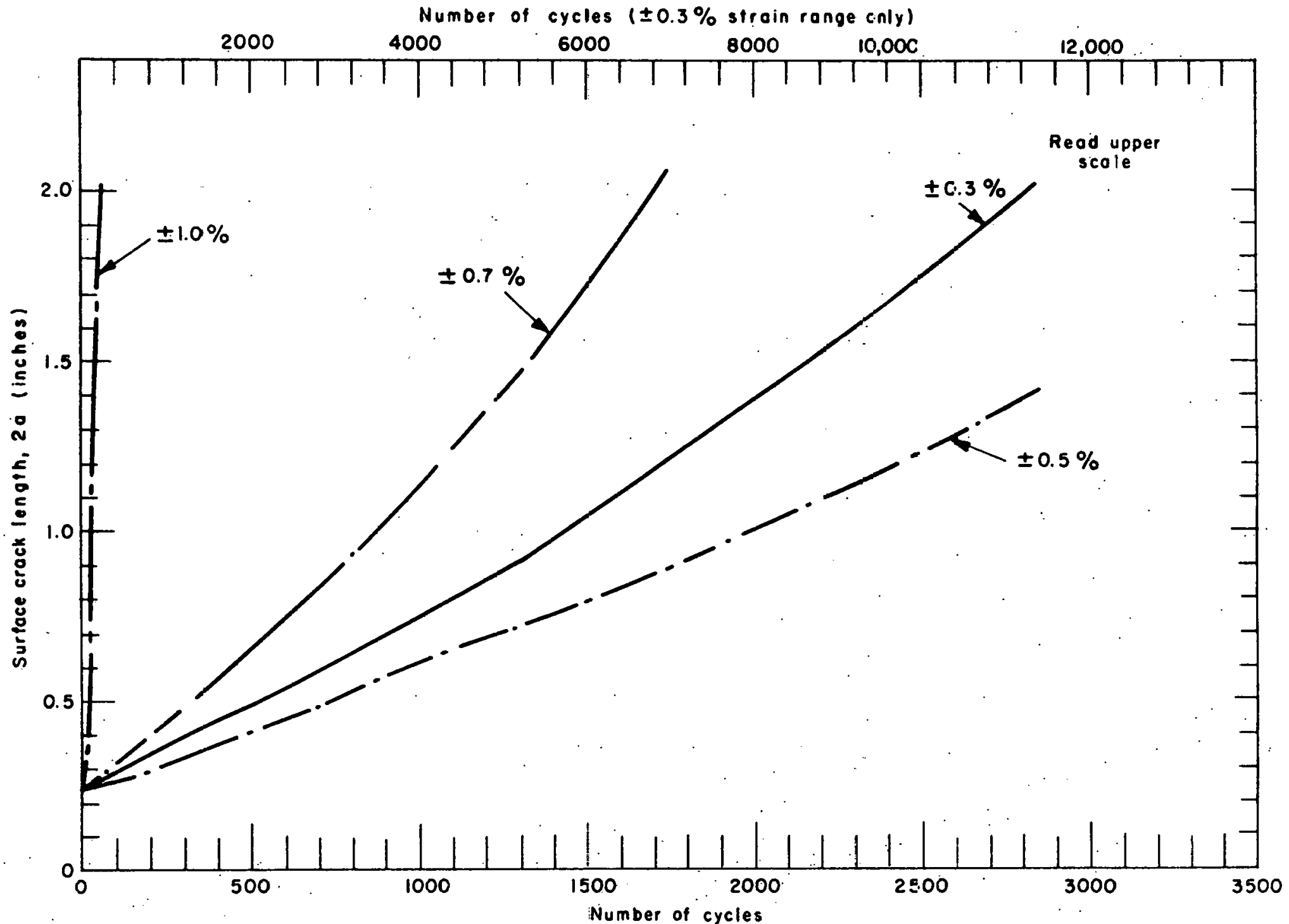

Figure 20. Crack Growth Cruves for. A-212B Carbon SteGl at Room Temperature in Reversed Beno-Loaded Beams 


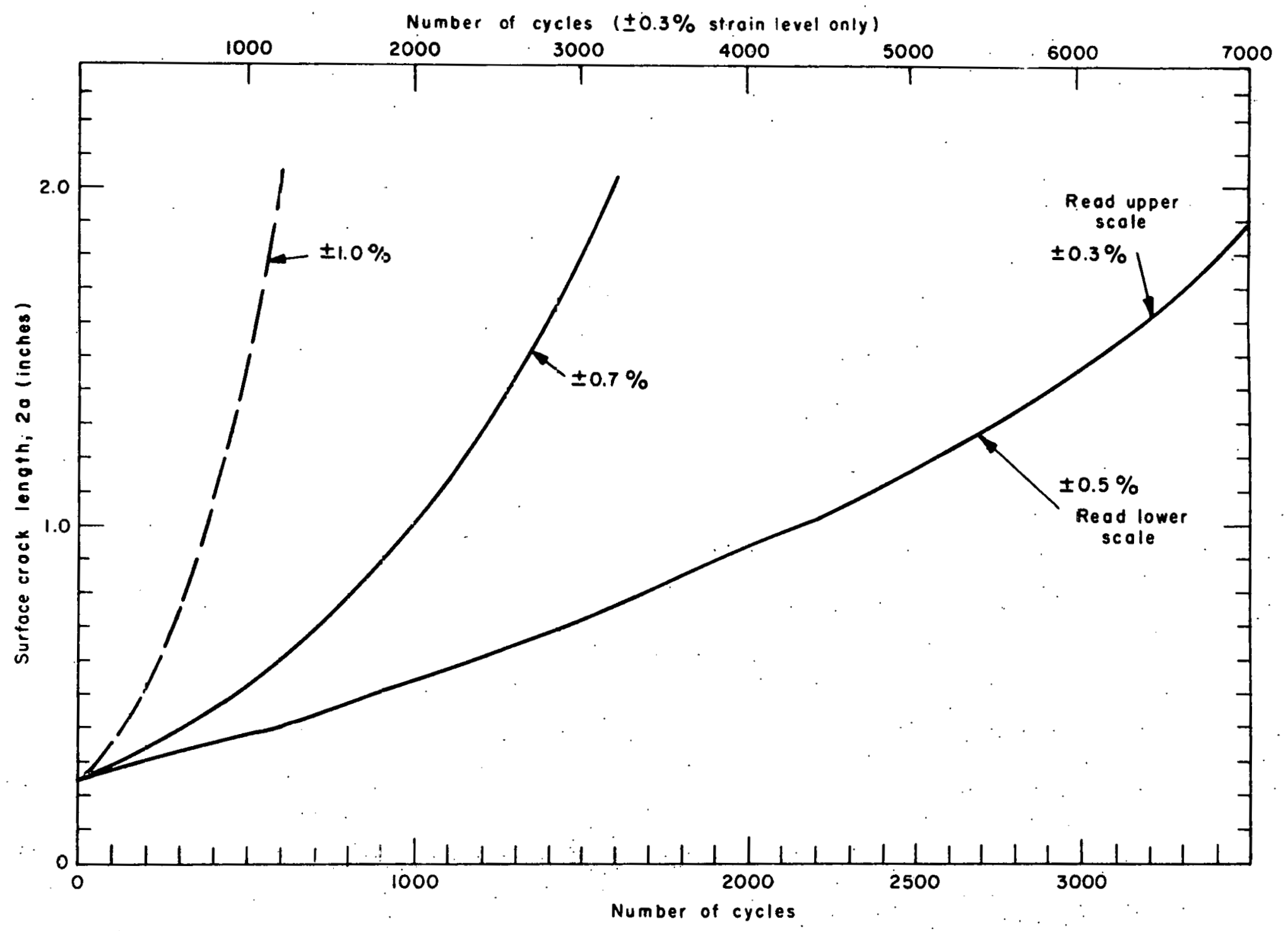

Figure 21. Crack Growth Curves for 2-1/4 Cr-1 Mo Steel at Room Temperature in Reversed Bend-Loaded Beams 


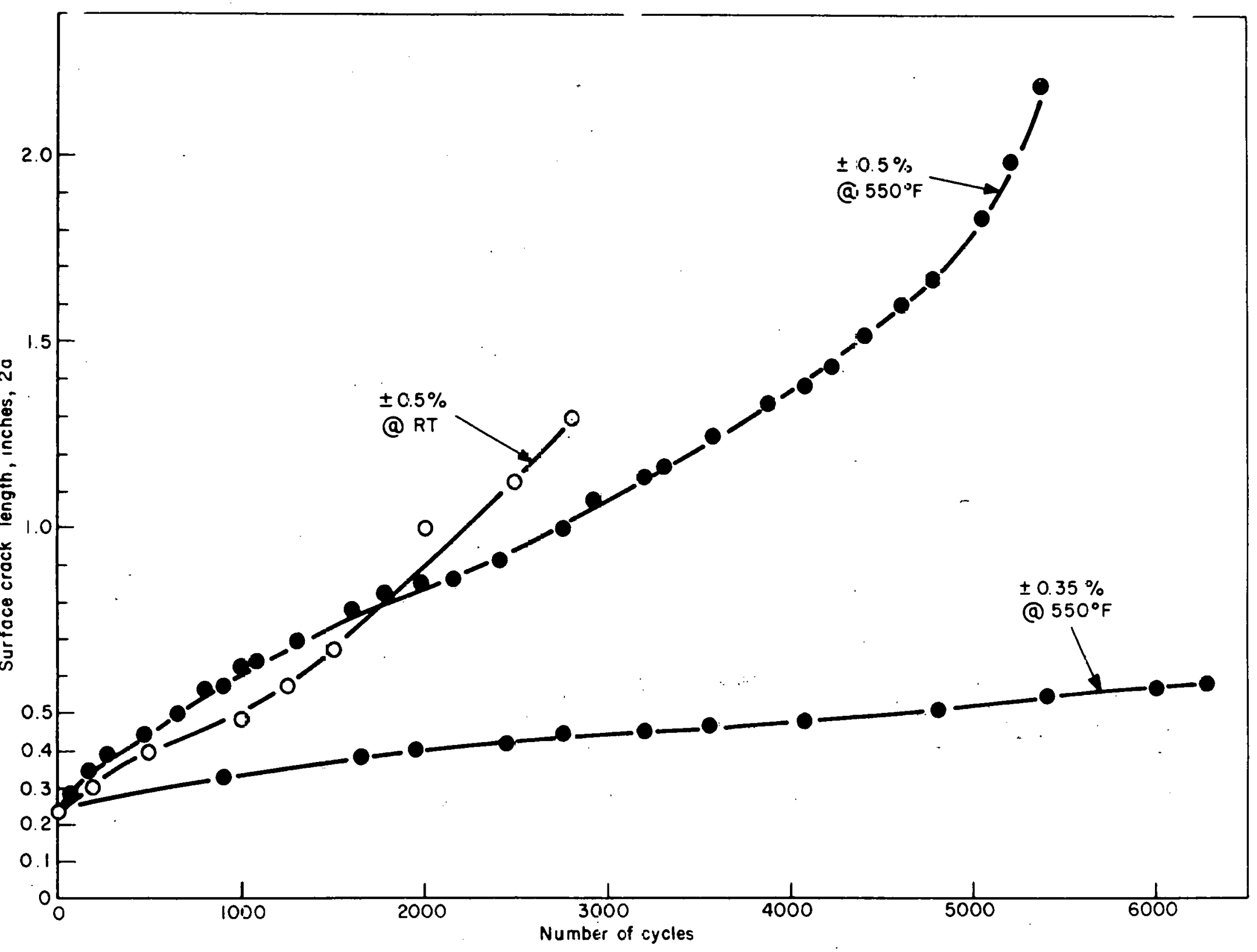

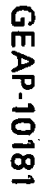

Figure 22 Crack Growth Cuives for Reverse-Loaded Bend Beams of $A 212 B$ at $5.50^{\circ} \mathrm{F}$ 


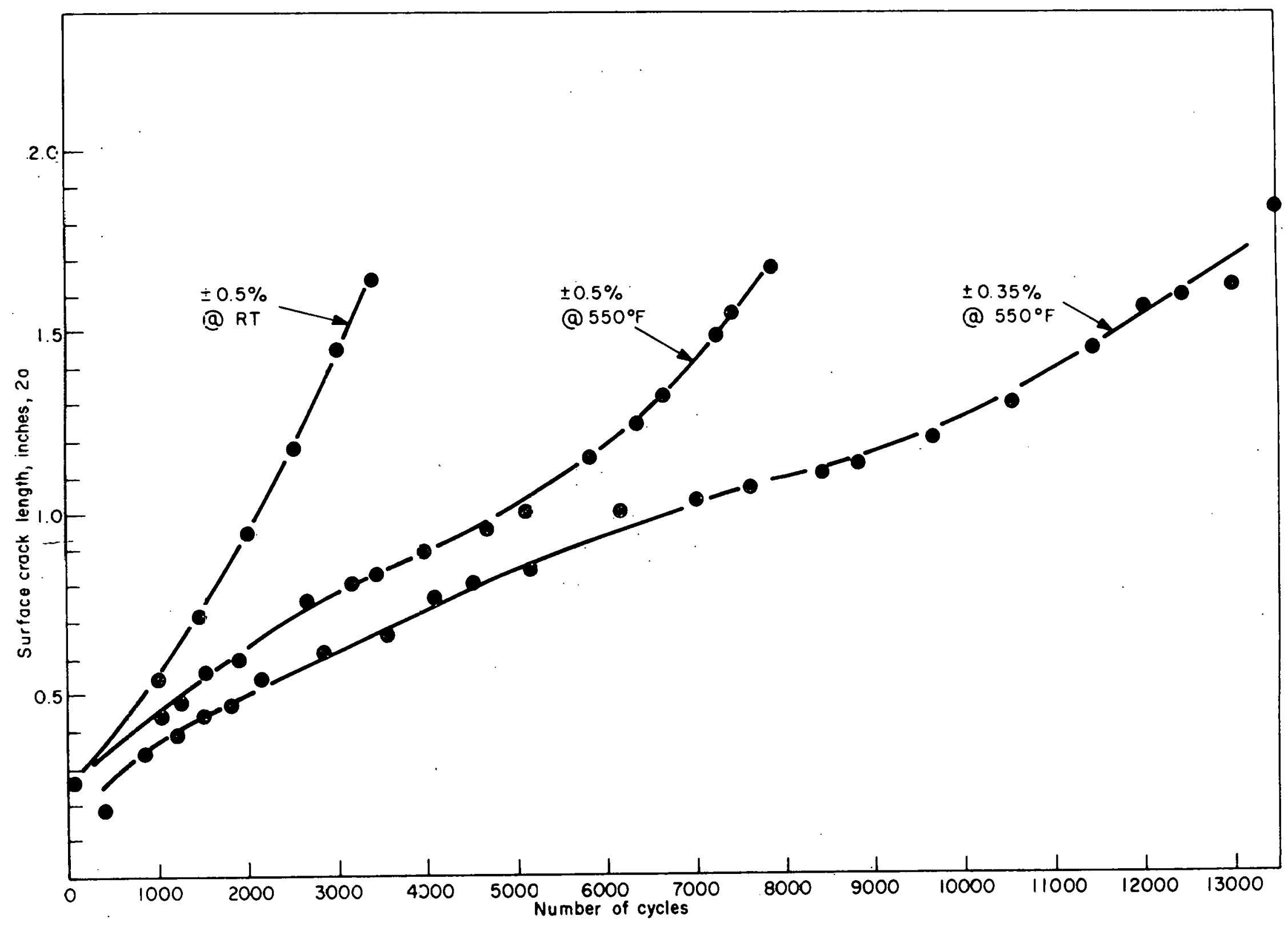

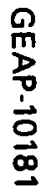

Figure 23. Crack Growth Cruves for Reverse-Loaded Beams of 2-1/4 Cr-1 Mo at $550^{\circ} \mathrm{F}$ 


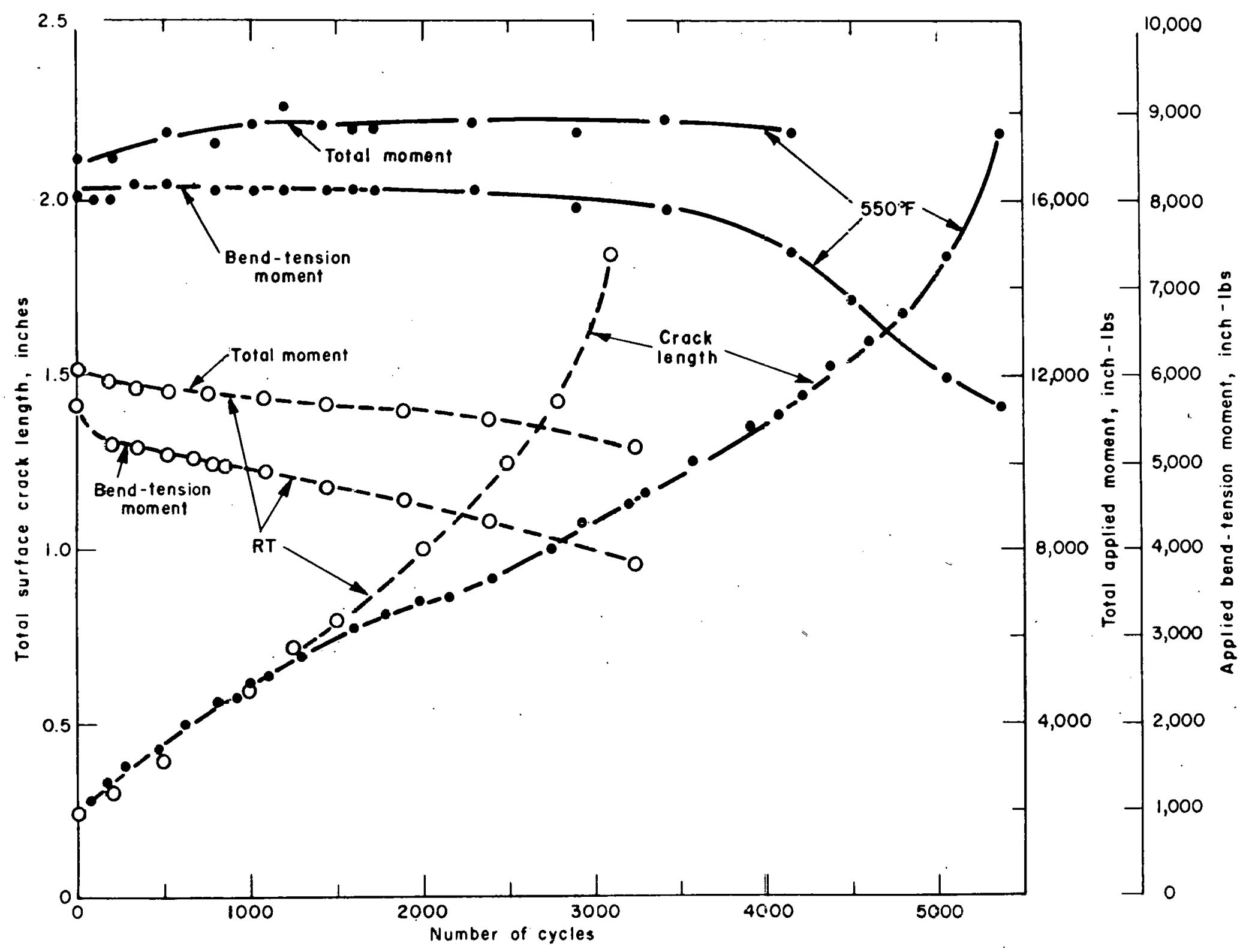

Figure 24. Crack Length and Applied Moments as a Function of Cycles fo: A-212B at Room Temperature and $550^{\circ} \mathrm{F}$ at $\pm 0.5 \%$ Total Strain 


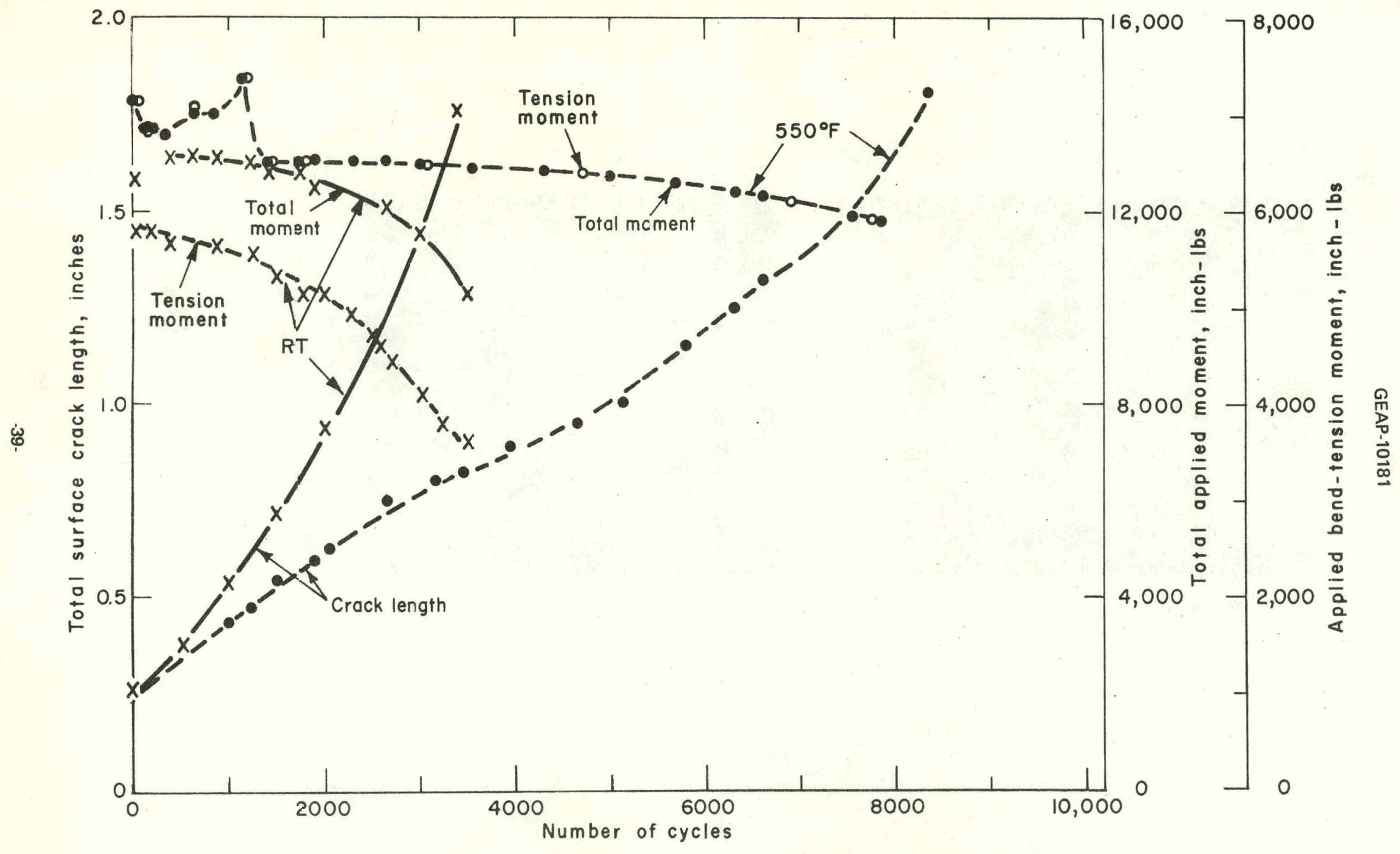

Figure 25. Crack Length and Applied Moment as a Funstion of Cycles for 2-1/4 Cr-1 Mo at Room Temperature and $550^{\circ} \mathrm{F}$ at $\pm 0.5 \%$ Total Strain 


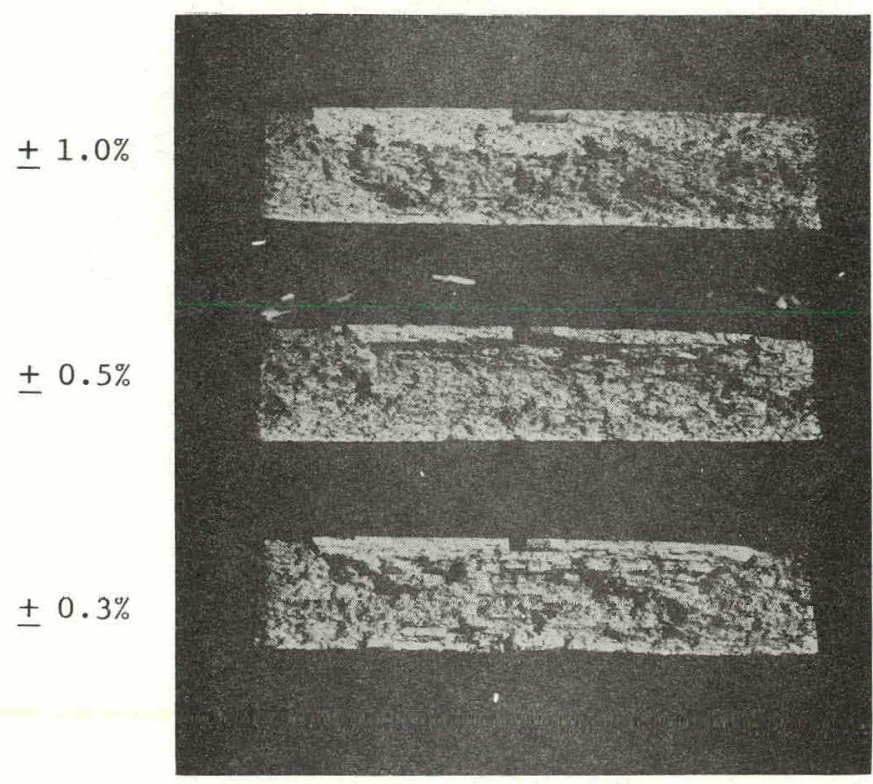

A-212B Carbon Stee1

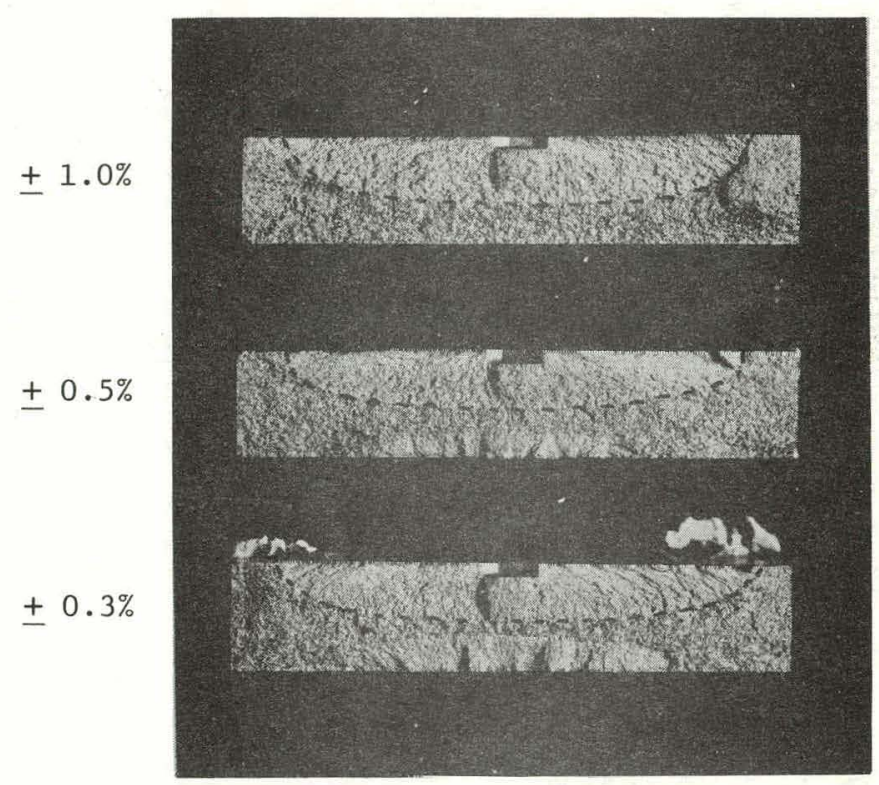

2 1/4Cr-1Mo Alloy

Figure 26. Fracture Surfaces of Bend Specimens at Room Temperature $1 X$ 

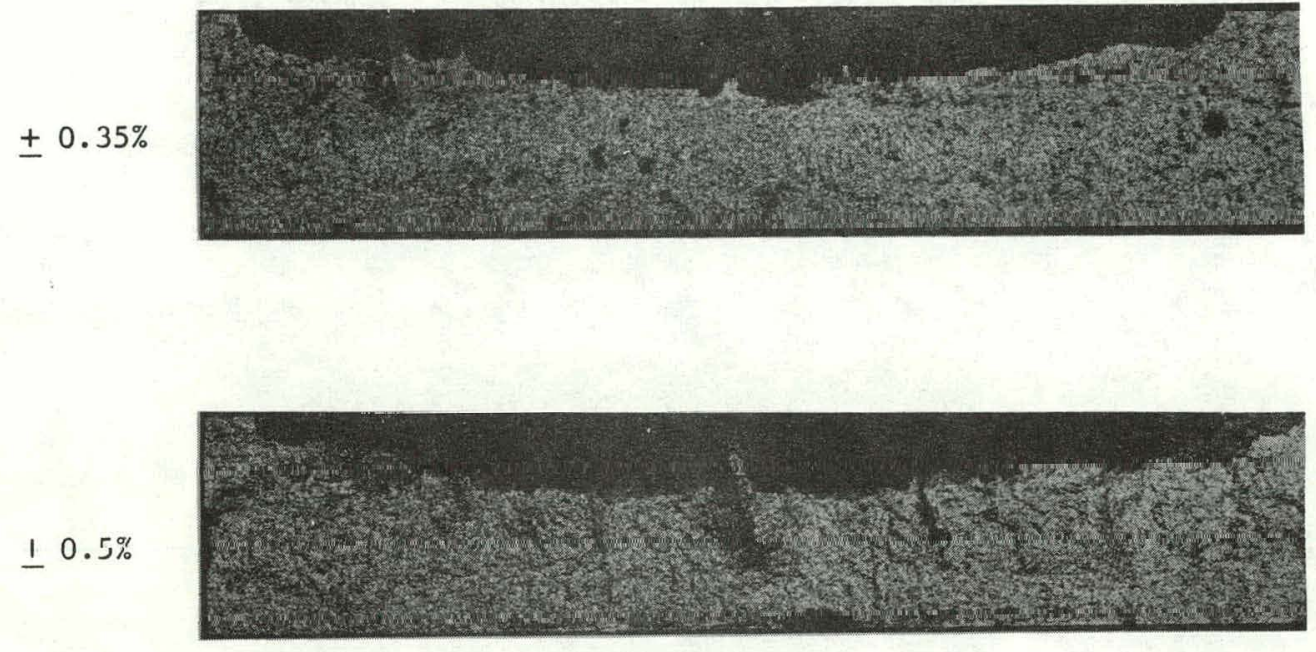

A-212B Carbon Steel

$\pm 0.35 \%$
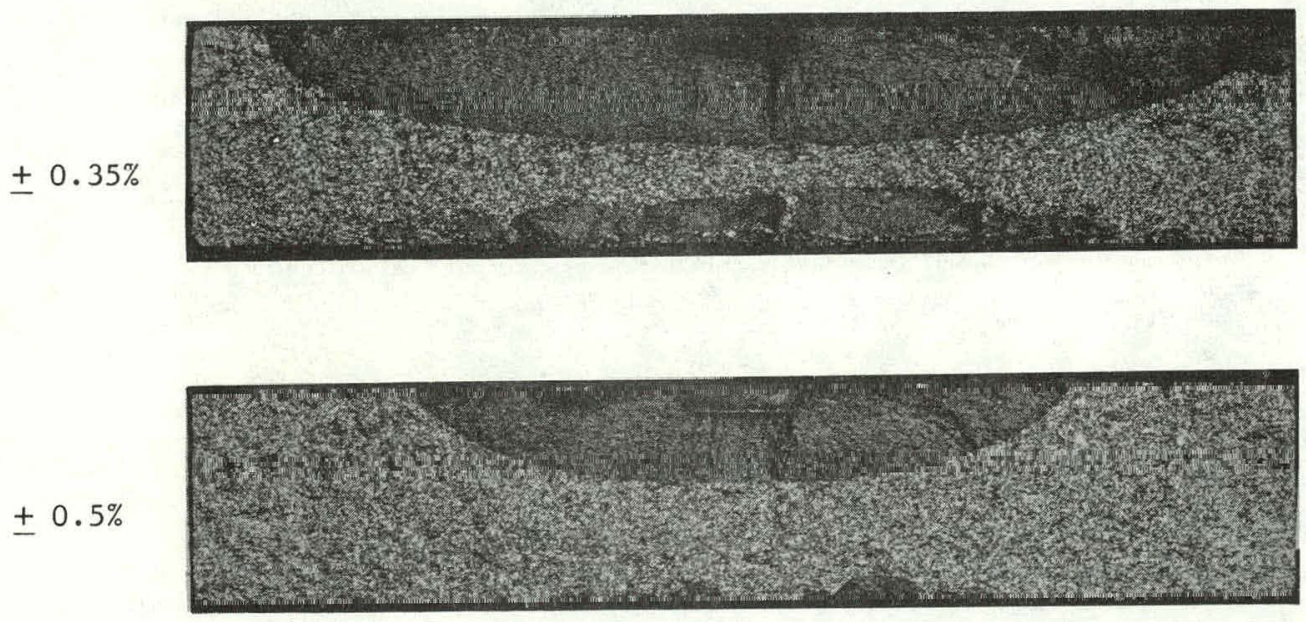

2 1/4 Cr-1 Mo Stee1

Figure 27. Fracture Surfaces of Bend Specimens at $550^{\circ} \mathrm{F} \quad 2 X$ 


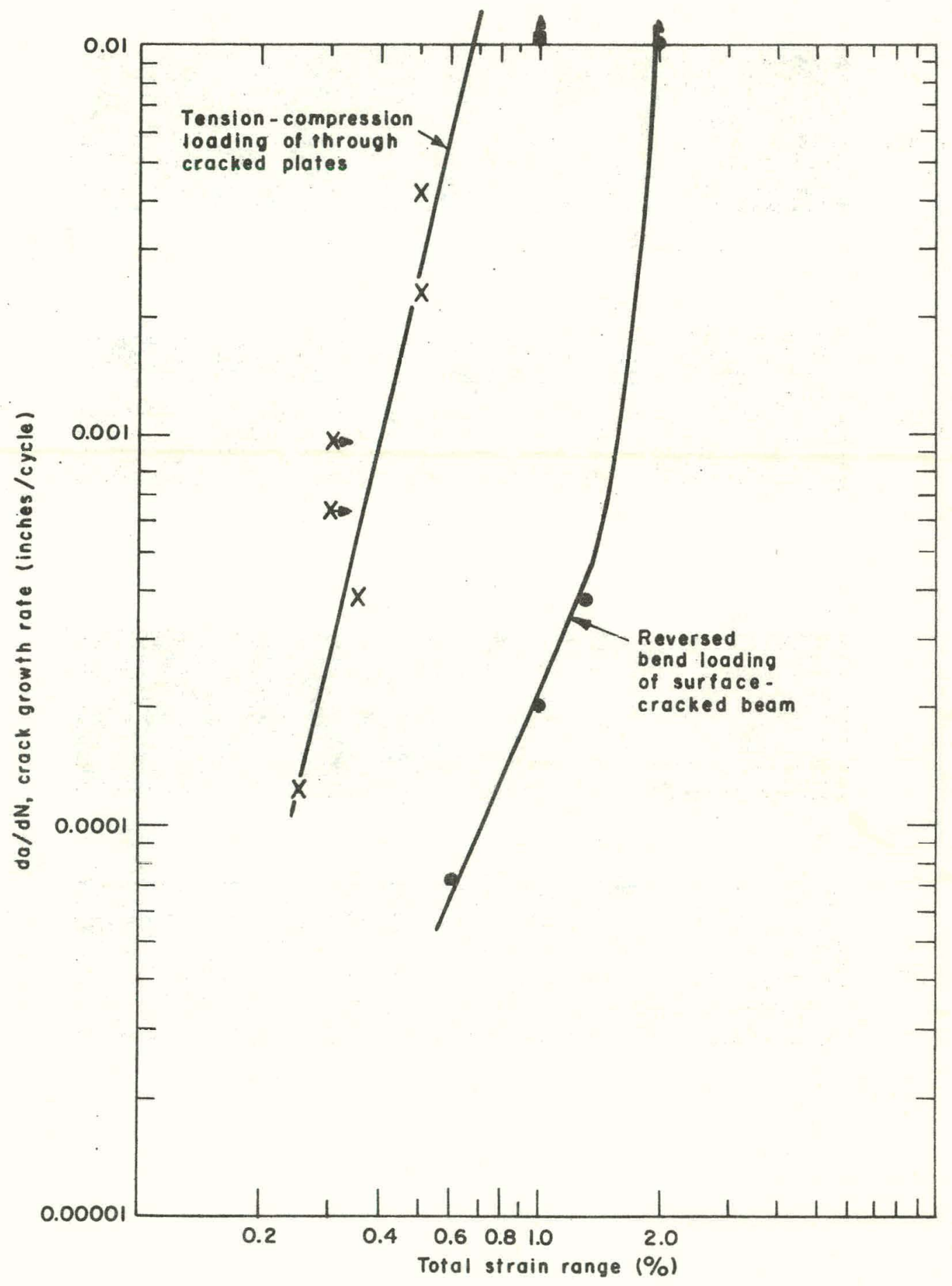

Figure 28. Comparison of Tension-Compression Versus Bend Loading on Correlation of Crack Growth Rate and Total Strain Range for A-212B Steel at Room Temperature 


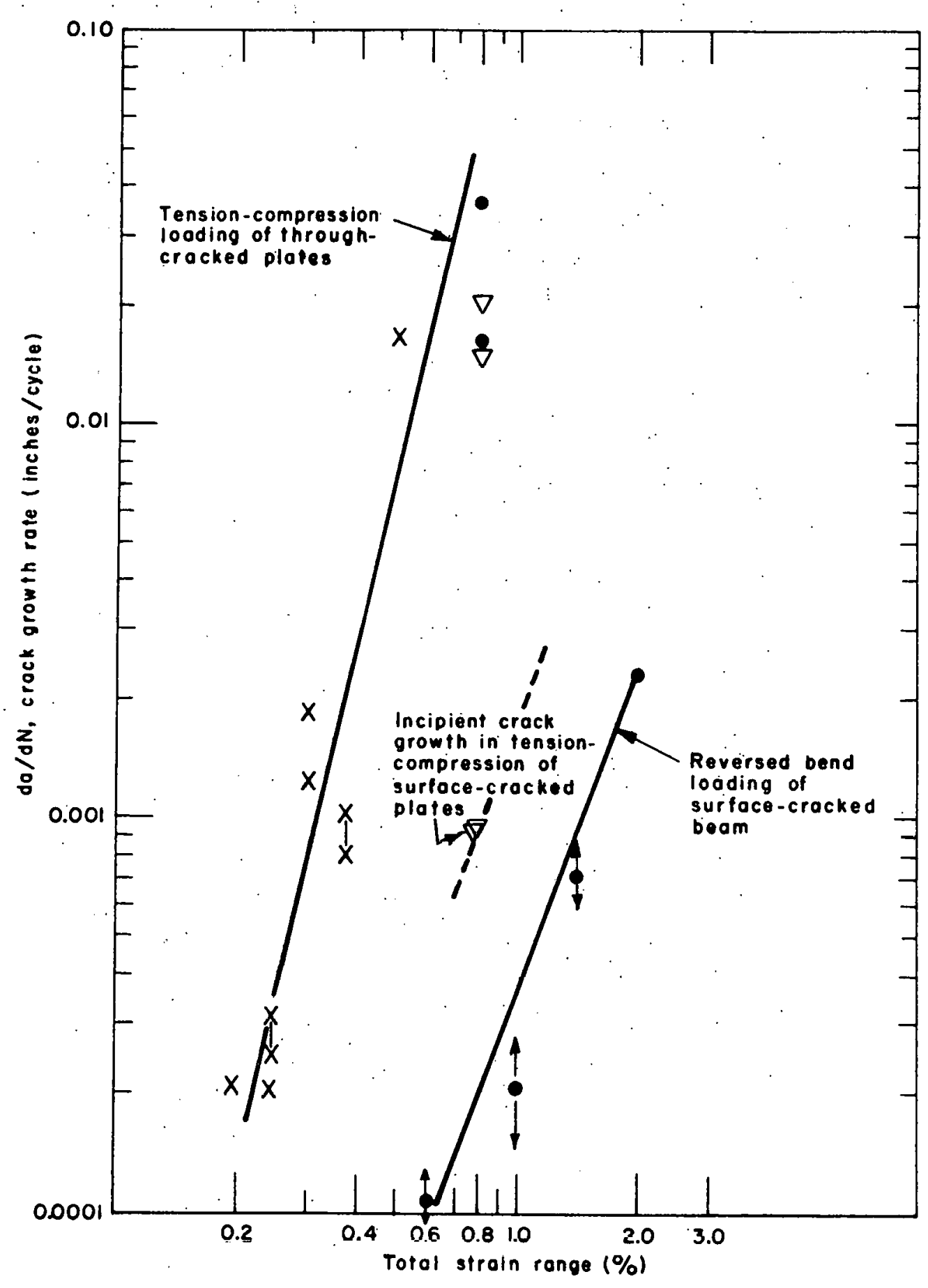

'Figure 29. Comparison of Tension-Compression Versus Bend Loading on Correlation of Crac:. Growth Rate and Total Strain Range For 2-1/4 Cr-1 Mo Alloy at Room Temper.a i ".. 


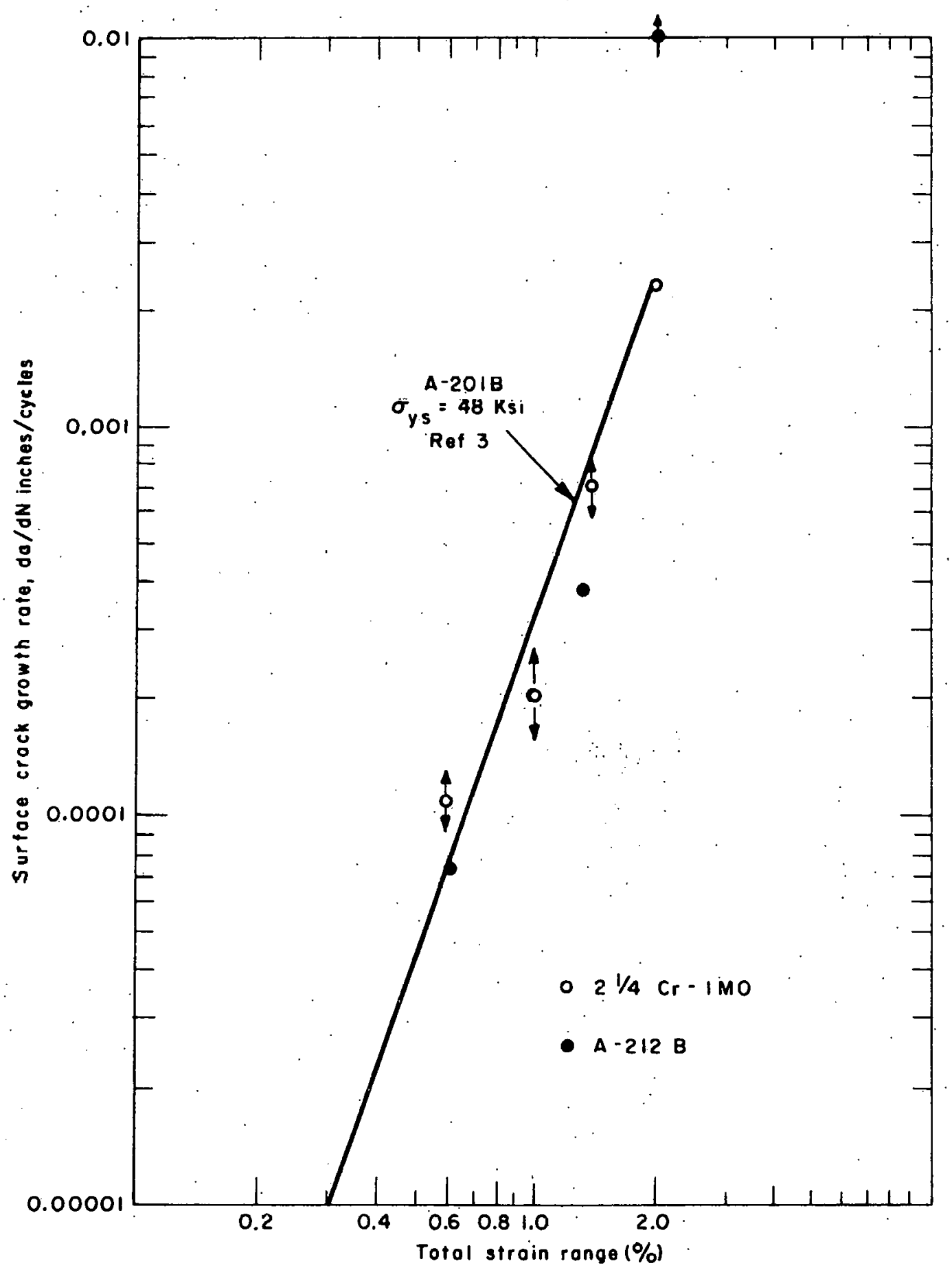

Figure 30. Comparison of 2-1/4 Cr-1 Mo and A-212B with A-201 Steel (Ref. 3) Tested as Surface-Cracked Cantilever Beams 


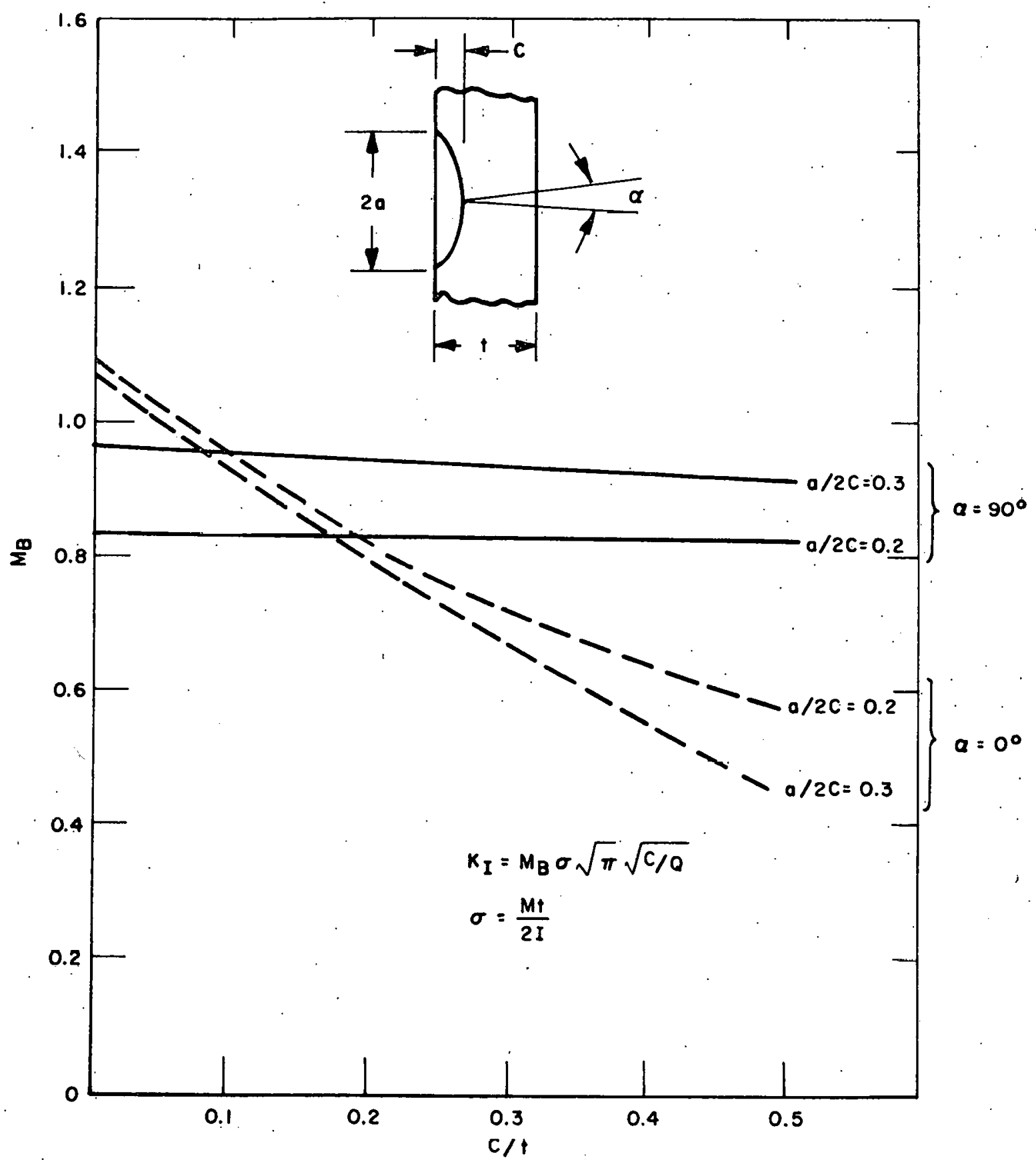

Figure 31. Approximate Stress Intensity Factors at $\alpha=0^{\circ}$ and $\alpha=90^{\circ}$ for Surface Flaws in Bending (Ref. 7) 
GEAP-10181

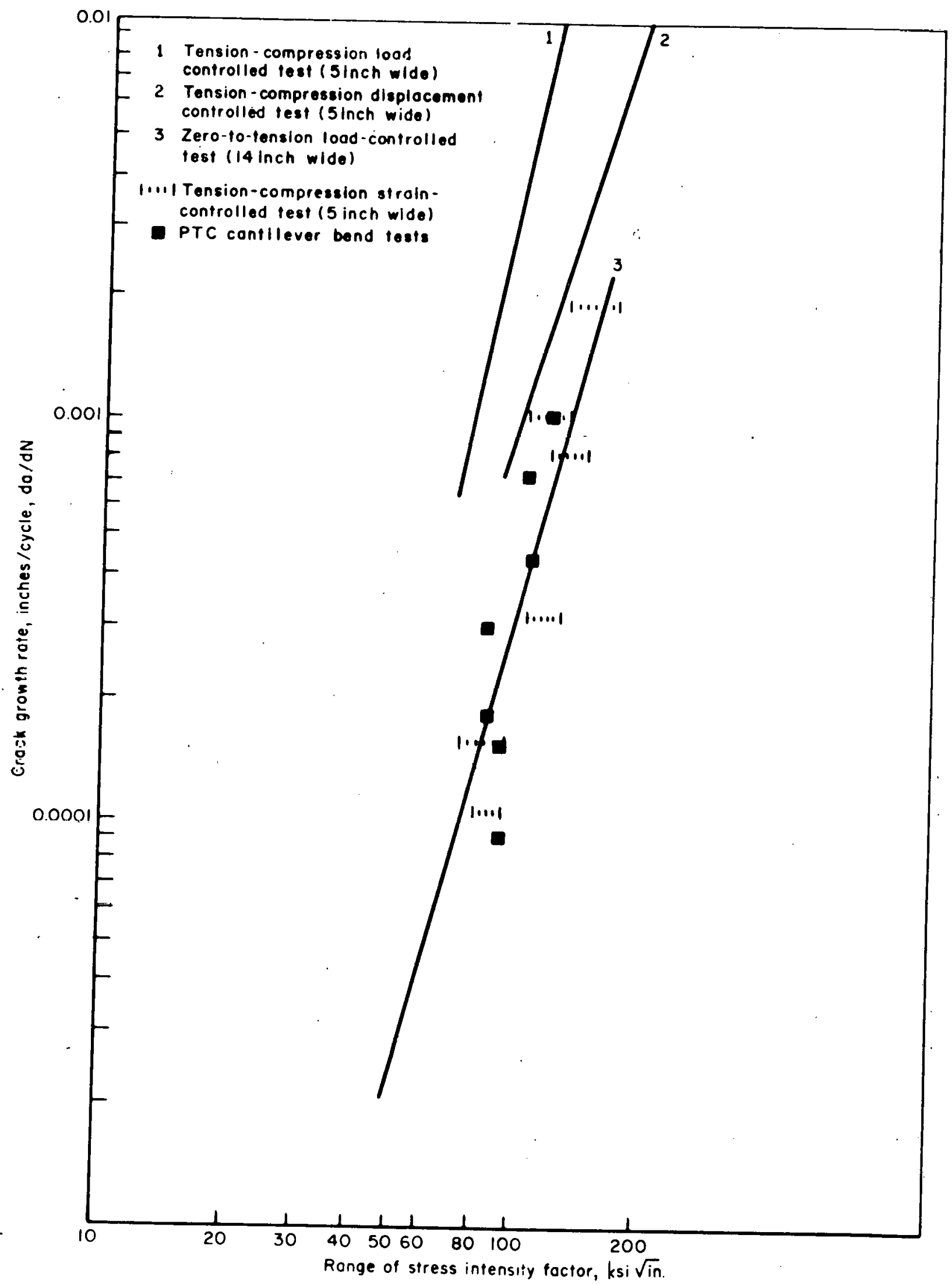

Figure 32. Crack Growth Correlation for 2-1/4 Cr-1 Mo Alloy Under Various Loading Schemes . 
APPENDIX

TABULATION OF CRACK GROWTH CURVES

\begin{tabular}{|c|c|c|c|c|c|}
\hline No. & \multicolumn{3}{|c|}{ Material } & $\begin{array}{l}\text { Temp. } \\
\left({ }^{\circ} \mathrm{F}\right) \\
\end{array}$ & $\begin{array}{c}\text { Total Strain } \\
\text { Range, } \% \\
\end{array}$ \\
\hline$A-1$ & $2-1 / 4$ & $\mathrm{C} C \mathrm{r}-1$ & Mo & RT & $0: 8$ \\
\hline$B-1$ & & 11 & . & $"$ & 00 \\
\hline$C-1$ & & $"$ & & $"$ & 0.8 \\
\hline$D-1$ & & $"$ & . & $"$ & 0.8 \\
\hline$E-1$ & & $"$ & & $"$ & $\therefore 0.6$ \\
\hline$F-1$ & & $"$ & & $"$ & 0.4 \\
\hline G-1 & & $"$ & & $"$ & $0.25,0.30,0.4$ \\
\hline$H-1$ & & $"$ & & $"$ & 1.0 \\
\hline$I-1$ & & $"$ & & $"$ & 0.25 \\
\hline$j-1$ & & $"$ & & $"$ & $0.25,0.30,0.40$ \\
\hline$k-1$ & & $"$ & & $"$ & 0.6 \\
\hline$L-1$ & & $"$ & & $"$ & .0 \\
\hline $\bar{M}-1$ & & $"$ & & 550 & 0.7 \\
\hline$N-1$ & & $"$ & & RT & 1.4 \\
\hline $0-1$ & & $"$ & & $"$ & 2.0 \\
\hline$P-1$ & & $"$ & & $"$ & 1.0 \\
\hline Q-1 & & $"$ & & $"$ & 0.4 \\
\hline$R-1$ & & $"$ & & $"$ & 0.4 \\
\hline$S-1$ & & $"$ & & $"$ & 0.4 \\
\hline$T-1$ & & $"$ & . & $"$ & 0.4 \\
\hline U-1 & & $"$ & & $"$ & 0.4 \\
\hline$V-T$ & & " & & 550 & $\because 1.0$ \\
\hline$A-2$ & & $A-212 B$ & & RT & 0.25 \\
\hline$B-2$ & & $"$ & & $"$ & 0.75 \\
\hline$C-2$ & & $"$ & & $"$ & 0.30 \\
\hline$D-2$ & & $"$ & & $"$ & 0.25 \\
\hline$E-2$ & & $"$ & & $"$ & 0.35 \\
\hline $\mathrm{F}-2$ & & ." & & 11 & 1.0 \\
\hline$G-2$ & & $"$ & & $"$ & 1.0 \\
\hline $\mathrm{H}-2$. & & $"$ & & $"$ & 0.6 \\
\hline$I-2$ & & $"$ & & $"$ & 1.0 \\
\hline$j-2$ & & $"$ & & $"$ & 0.7 \\
\hline$k-2$ & & $"$ & & $"$ & 1.0 \\
\hline$i-2$ & & $"$ & & $"$ & 1.4 \\
\hline$M-2$ & & $"$ & & 550 & 1.0 \\
\hline$N-2$ & & $"$ & & $"$ & 0.7 \\
\hline$A-3$ & & ype 304 & & $"$ & $0: 78$ \\
\hline$B-3$ & & " & & $"$ & 0.25 \\
\hline$C-1$ & & $"$ & & $"$ & 0.4 \\
\hline & & $"$ & & $"$ & 0.6 \\
\hline & & $"$ & & $"$ & 0.75 \\
\hline F-3 & & $"$ & & $"$ & 1.0 \\
\hline
\end{tabular}

Notes

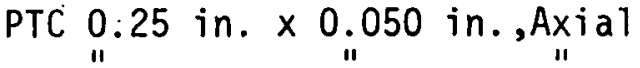

Through-cracked plate; Axial

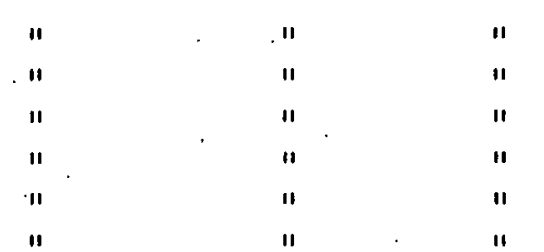

Part-through crack, bending

Part-through crack, Axial, 0.8 in.

Face-slotted plate

Part-through crack, Bending

Through-cracked plate, Axial

Part-through crack, Bending

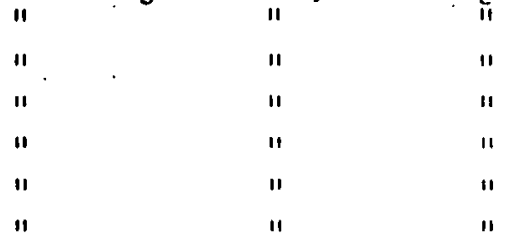

Through-cracked plate, Axial 
Sper:.: $\quad h-1$-Axial

$2-1,4 \mathrm{Cr}-1$ Mo

GEAP-10181

RT

Total Strain Range: $0.8 \%$

$0.25^{\prime \prime}$ Plate - PTC $0.25^{\prime \prime} \times 0.050^{\prime \prime}$

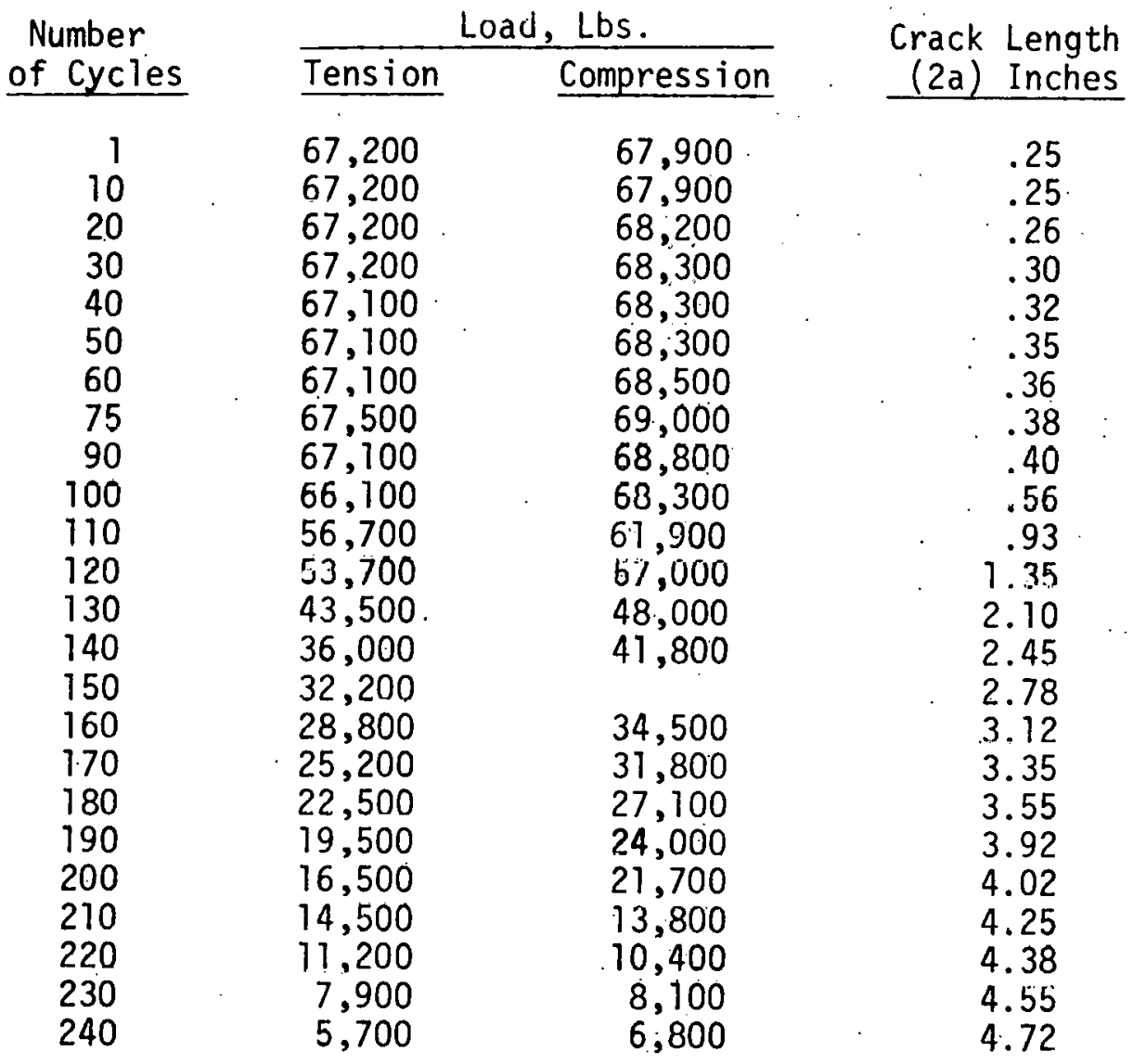


$2-1 / 4 \mathrm{Cr}-1 \mathrm{Mo}$

RT

Total Strain Range: $0.8 \%$

$0.25^{\prime \prime}$ Plate - PTC $0.25^{\prime \prime} \times 0.050^{\prime \prime}$

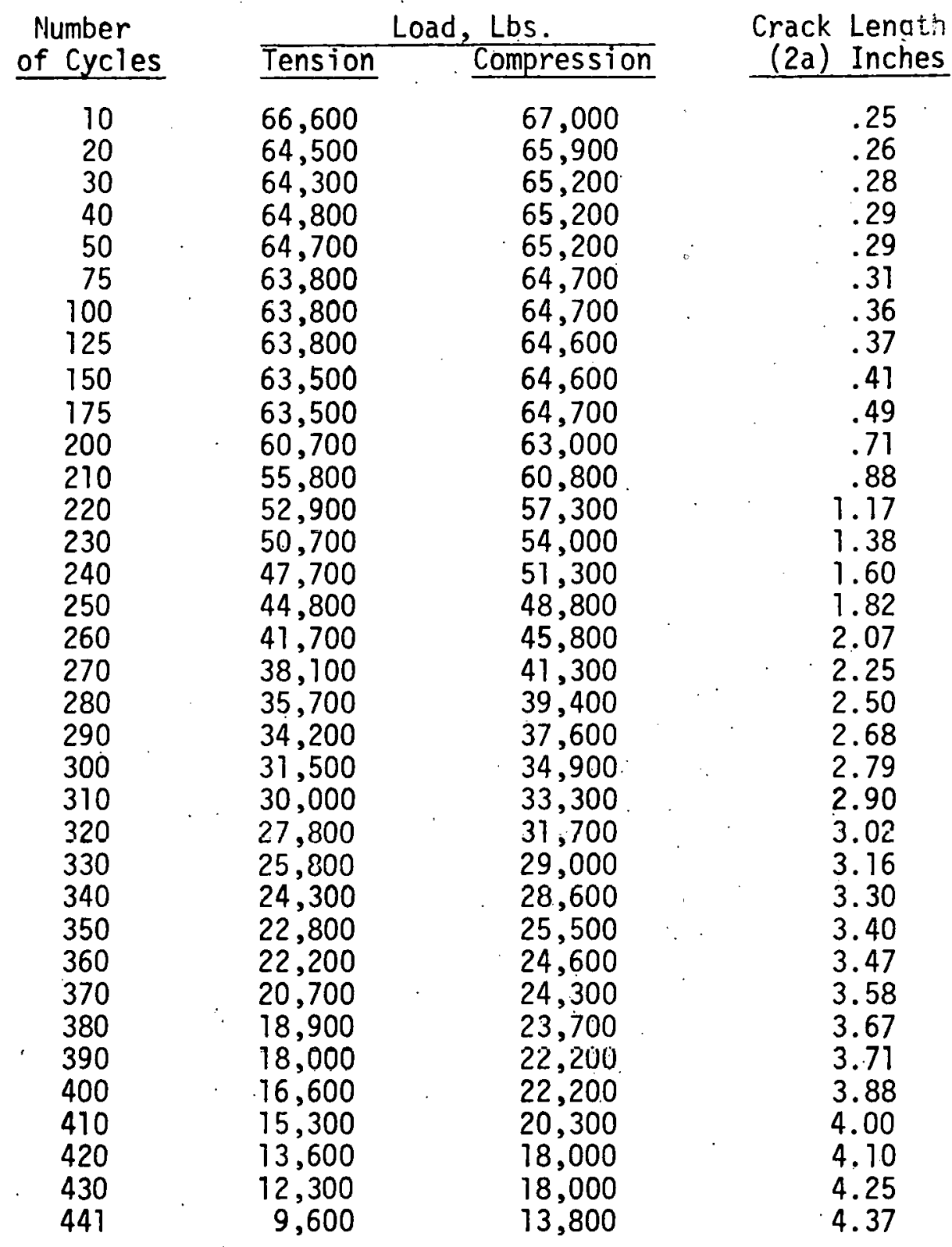


Spec: $\quad C-1-A x i a 1$

$2-1 / 4 \mathrm{Cr}-1 \mathrm{Mo}$

GEAP-10181

RT

Total Strain Range: $0.8 \%$

\begin{tabular}{|c|c|c|c|}
\hline $\begin{array}{c}\text { Number } \\
\text { of Cycles }\end{array}$ & Tension & Lompression & $\begin{array}{r}\text { Crack Length } \\
2 \text { (a) Inches }\end{array}$ \\
\hline 10 & 70,800 & 73,200 & .11 \\
\hline 20 & 70,100 & 72,800 & .15 \\
\hline 30 & 48,100 & 72,200 & .23 \\
\hline 42 & - & - &. .40 \\
\hline 50 & 63,100 & 68,400 & .75 \\
\hline 60 & 58,500 & 63,800 & .1 .04 \\
\hline 70 & 48,800 & $52,800 \ldots$ & 1.58 \\
\hline 80 & 46,500 & 52,800 & 1.95 \\
\hline 90 & 39,800 & 45,7000 & 2.32 \\
\hline 100 & 35,200 & 41,400 & 2.70 \\
\hline 110 & 30,800 & 36,100 & 3.02 \\
\hline 120 & 26,700 & 32,100 & 3.32 \\
\hline 130 & 22,600 & 28,500 & 3.56 \\
\hline 140 & 18,600 & 23,700 & 3.82 \\
\hline 150 & 16,500 & 22,500 & 4.02 \\
\hline 160 & 13,500 & 18,600 & 4.14 \\
\hline 170 & 9,600 & 16,500 & 4.38 \\
\hline 180 & $5,7 \cup 0 U$ & 11,700 & $\therefore 4.67$ \\
\hline 186 & - & - & 4.92 \\
\hline
\end{tabular}


Spec: D-1-Axial

$2-1 / 4 \mathrm{Cr}-1 \mathrm{Mo}$

RT

Tota) Strain Range: $0.8 \%$

\begin{tabular}{|c|c|c|c|c|}
\hline Number & \multicolumn{2}{|c|}{ Load, Lbs. } & \multirow{2}{*}{$\begin{array}{r}\text { Crack } \\
(2 a) \\
\end{array}$} & \multirow{2}{*}{$\begin{array}{l}\text { Length } \\
\text { Inches }\end{array}$} \\
\hline of Cycles & Tension & Compression & & \\
\hline 2 & 66,300 & 67,300 & & .11 \\
\hline 10 & 67,300 & 67,700 & & .23 \\
\hline 20 & 63,800 & 67,300 & & .41 \\
\hline 30 & 61,400 & 67,700 & & .70 \\
\hline 40 & 52,700 & 58,100 & & 1.28 \\
\hline 50 & 45,400 & 50,200 & & 1.75 \\
\hline 60 & 40,200 & 45,800 & & 2.20 \\
\hline 70 & 35,300 & 40,800 & & 2.60 \\
\hline 80 & 31,700 & 38,000 & & 2.82 \\
\hline 90 & 27,300 & 33,400 & & 3.06 \\
\hline 100 & 25,600 & 31,200 & & 3.22 \\
\hline 110 & 22,800 & 27,800 & & 3.46 \\
\hline 120 & 20,300 & 26,000 & & 3.61 \\
\hline 130 & 17,700 & 23,000 & & 3.83 \\
\hline 140 & 15,400 & 20,800 & & 3.97 \\
\hline 150 & 13,600 & 19,600 & & 4.14 \\
\hline 160 & 10,800 & 17,100 & & 4.30 \\
\hline 170 & 9,000 & 15,000 & & 4.48 \\
\hline 180 & 3,700 & 10,800 & & 4.69 \\
\hline
\end{tabular}


Spec: E-1-Axial

$2-1 / 4 \mathrm{Cr}$ - $1 \mathrm{Mo}$

RT

Total Strain Range, $0.6 \%$

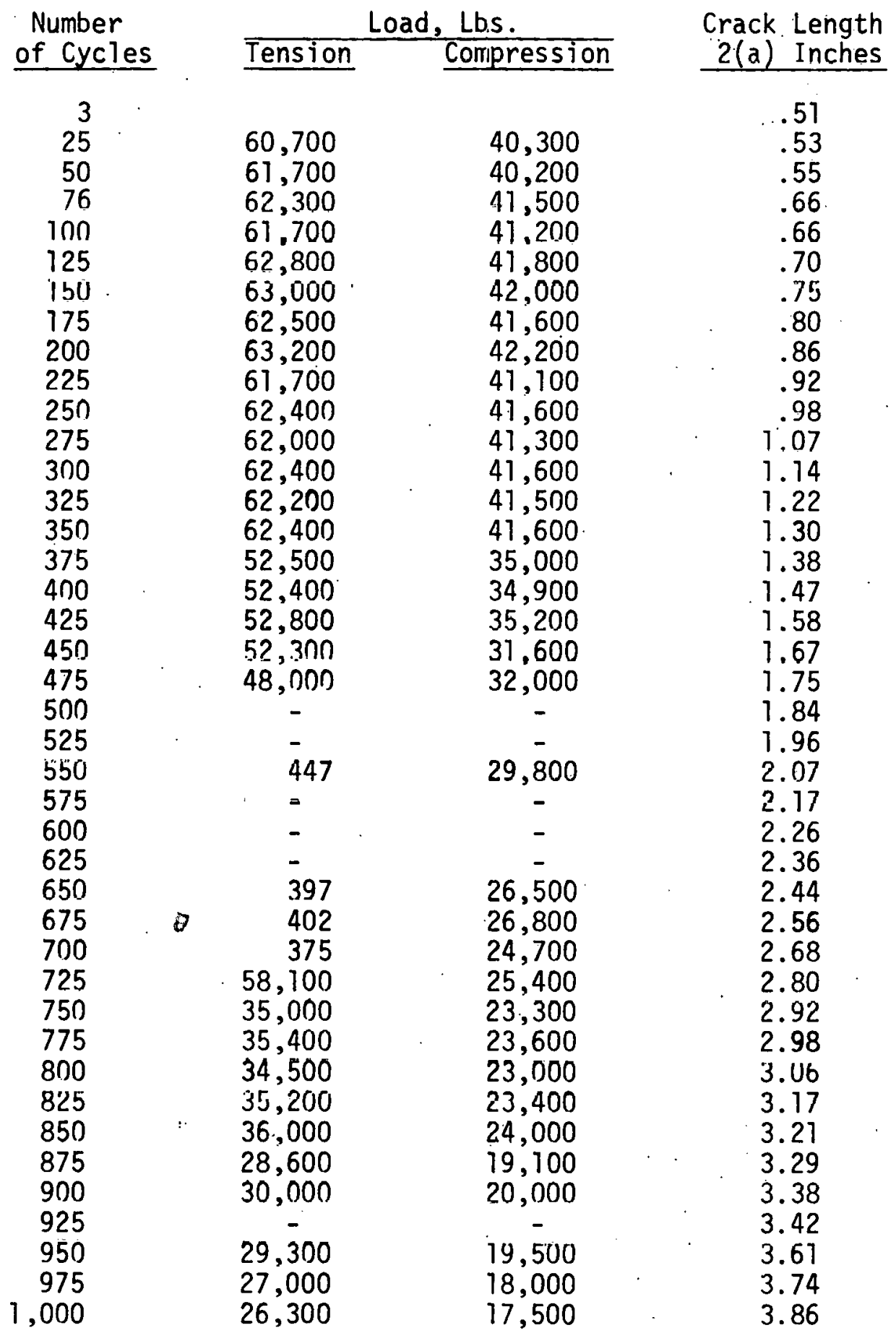


Spec: F-1-Axial

2-1/4 $\mathrm{Cr}-1$ : Mo

P.T

Total Strain Ranqe: $0.4 \%$

\begin{tabular}{|c|c|c|c|}
\hline Number & \multicolumn{2}{|c|}{ Load, Lbs. } & \multirow{2}{*}{$\begin{array}{l}\text { Crack Lenath } \\
2 \text { (a) Inches }\end{array}$} \\
\hline & Tension & Compression & \\
\hline 1 & 84,200 & 56,000 & .52 \\
\hline 40 & - & - & .56 \\
\hline $\begin{array}{l}50 \\
75\end{array}$ & $\begin{array}{l}66,200 \\
66,200\end{array}$ & 44,200 & $\begin{array}{l}.62 \\
70\end{array}$ \\
\hline $\begin{array}{r}75 \\
100\end{array}$ & $\begin{array}{l}60,200 \\
65,300\end{array}$ & $\begin{array}{l}44,200 \\
43,500\end{array}$ & $\begin{array}{l}.70 \\
.77\end{array}$ \\
\hline 125 & 65,300 & 42,500 & .82 \\
\hline 150 & 62,300 & 41,500 & .90 \\
\hline 175 & - & - & .96 \\
\hline 200 & $60,7: 00$ & 40,500 & 1.02 \\
\hline 225 & 60,600 & 40,300 & 1.07 \\
\hline 250 & 57,800 & 38,500 & 1.11 \\
\hline 275 & 55,800 & 37,200 & 1.16 \\
\hline 300 & 57,000 & 38,000 & 1.21 \\
\hline 325 & 56,300 & 37,500 & 1.25 \\
\hline 350 & 56,300 & 35,000 & 1.30 \\
\hline 375 & 56,200 & 37,400 & 1.36 \\
\hline 400 & 52,800 & 38,500 & 1.41 \\
\hline 425 & 53,200 & 35.500 & 1.45 \\
\hline 450 & 54,700 & 36.500 & $\begin{array}{r}7.49 \\
159\end{array}$ \\
\hline $\begin{array}{l}500 \\
525\end{array}$ & $\begin{array}{l}52,800 \\
53,200\end{array}$ & $\begin{array}{l}35,200 \\
35,500\end{array}$ & $\begin{array}{l}1.59 \\
1.64\end{array}$ \\
\hline 550 & 52,200 & 34,800 & 1.69 \\
\hline 575 & 51,700 & 34,500 & 1.74 \\
\hline $600^{\circ}$ & 57,700 & 23,500 & 1.78 \\
\hline 650 & 46,000 & 30,700 & 1.87 \\
\hline $\begin{array}{l}675 \\
700\end{array}$ & 45,700 & 30,500 & $\begin{array}{r}1.91 \\
1.95\end{array}$ \\
\hline $\begin{array}{l}700 \\
725\end{array}$ & $\begin{array}{l}45,400 \\
46,300\end{array}$ & $\begin{array}{l}30,300 \\
30,900\end{array}$ & $\begin{array}{l}1.95 \\
2.00\end{array}$ \\
\hline 750 & 43,000 & 30,700 & 2.04 \\
\hline 775 & 43,000 & 28,700 & 2.07 \\
\hline 800 & 42,700 & 28,500 & 2.91 \\
\hline 825 & 43,200 & 28,800 & 2.76 \\
\hline 850 & $43,30 n$ & 28,900 & 2.19 \\
\hline 875 & 43,500 & 29,000 & 2.23 \\
\hline 900 & 42,700 & 28,500 & 2.27 \\
\hline 925 & 42,700 & 28,000 & 2.31 \\
\hline 950 & 42,700 & 28,500 & 2.36 \\
\hline 975 & 40,600 & 27,000 & 2.40 \\
\hline ו, ו, & 41,200 & 27,400 & 2.44 \\
\hline 1,025 & 40,200 & 26.800 & 2.49 \\
\hline 1,050 & 40,200 & 26,800 & 2.53 \\
\hline 1,100 & 39,600 & 26,400 & 2.62 \\
\hline 1,125 & 37,700 & 25,100 & 2.65 \\
\hline & 36,800 & 24,500 & 2.69 \\
\hline
\end{tabular}

(cont'd.) 
Spec: F-l-Axial (cont'd.)

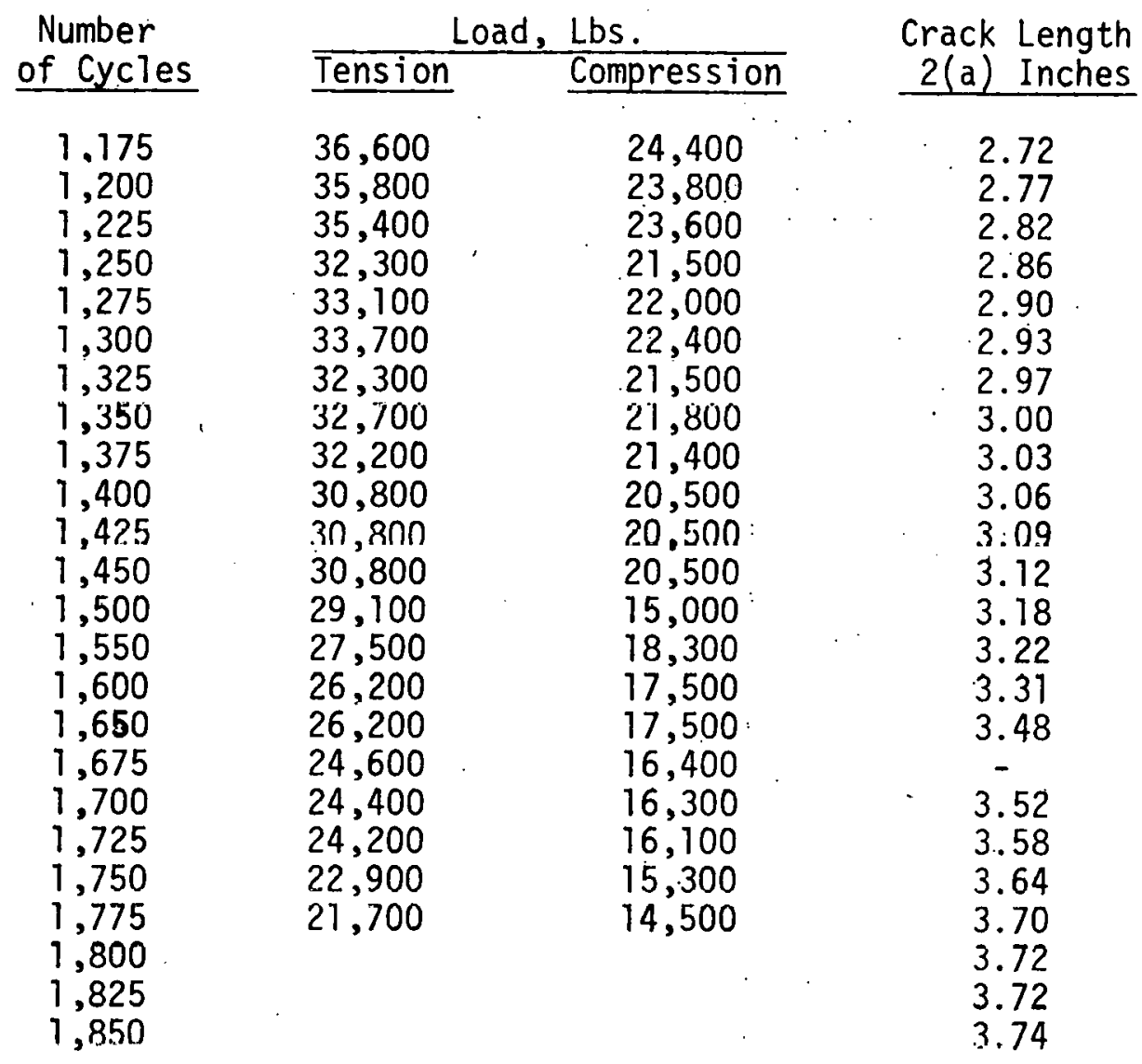


Spec: G-1-Axial

RT

Total Strain Range: $0.25 \%, 0.30 \%, 0.4 \%$

\begin{tabular}{ccccc}
$\begin{array}{c}\text { Number } \\
\text { of Cycles }\end{array}$ & & \multicolumn{2}{c}{ Load, Lbs. } & \multicolumn{2}{c}{$\begin{array}{c}\text { Crack Length } \\
\text { Tension }\end{array}$} & Compression & & \multicolumn{1}{c}{ 2(a), Inches } \\
\cline { 5 - 5 } 32 & & 46,600 & 49,600 & \\
225 & 46,200 & 48,700 & .50 \\
385 & & 4 & \\
500 & 45,800 & 46,200 & .60 \\
733 & 45,800 & 48,700 & .65 \\
825 & 46,200 & 49,500 & .69 \\
827 & & 43,500 & 45,800 & .73 \\
1,015 & & &
\end{tabular}

Increased strain to $+0.15 \%$

$\begin{array}{llll}1,025 & 45,800 & 50,800 & .73 \\ 1,290 & 45,200 & 49,400 & .84 \\ 1,535 & 44,800 & 44,800 & .91 \\ 1,840 & 42,800 & 40,600 & 1.02 \\ 2,080 & 43,500 & 44,300 & 1.06 \\ 2,100 & 46,600 & 51,800 & 1.08\end{array}$

Increased strain to $+0.20 \%$

$\begin{array}{llll}2,150 & 46,600 & 51,000 & 1.10 \\ 2,200 & 46,600 & 51,800 & 1.13 \\ 2,250 & 46,600 & 51,800 & 1.16 \\ 2,300 & 44,300 & 51,800 & 1.79 \\ 2,350 & 46,600 & 52,700 & 1.22 \\ 2,400 & 46,600 & 52,700 & 1.24 \\ 2,450 & 45,000 & 51,000 & 1.26 \\ 2,500 & 44,300 & 49,600 & 1.28 \\ 2,550 & 45,000 & 49,800 & 1.30 \\ 2,600 & 44,200 & 49,500 & 1.33 \\ 2,650 & 45,000 & 49,500 & 1.36 \\ 2,750 & 43,500 & 45,700 & 1.41 \\ 2,800 & 43,500 & 45,700 & 1.43 \\ 2,850 & 42,800 & 45,500 & 1.46 \\ 2,900 & 42,800 & 45,500 & 1.48 \\ 2,950 & 38,600 & 45,300 & 1.51 \\ 3,000 & 42,600 & 45,000 & 1.53 \\ 3,050 & 42,700 & 45,300 & 1.56 \\ 3,100 & 42,800 & 45,700 & 1.58 \\ 3,150 & 42,600 & 45,500 & 1.61 \\ 3,300 & 41,200 & 44,700 & 1.69 \\ 3,350 & 40,500 & 41,200 & 1.72 \\ 3,400 & 40,500 & 42,000 & 1.75 \\ 3,450 & 40,200 & 42,000 & 1.79 \\ 3,500 & 39,600 & 39,700 & 1.82 \\ 3,550 & 39,700 & 39,700 & 1.84 \\ 3,600 & 39,600 & 40,200 & 1.86 \\ 3,650 & 39,400 & 39,700 & 1.88\end{array}$


Spec: G-l-Axial (cont'd.)

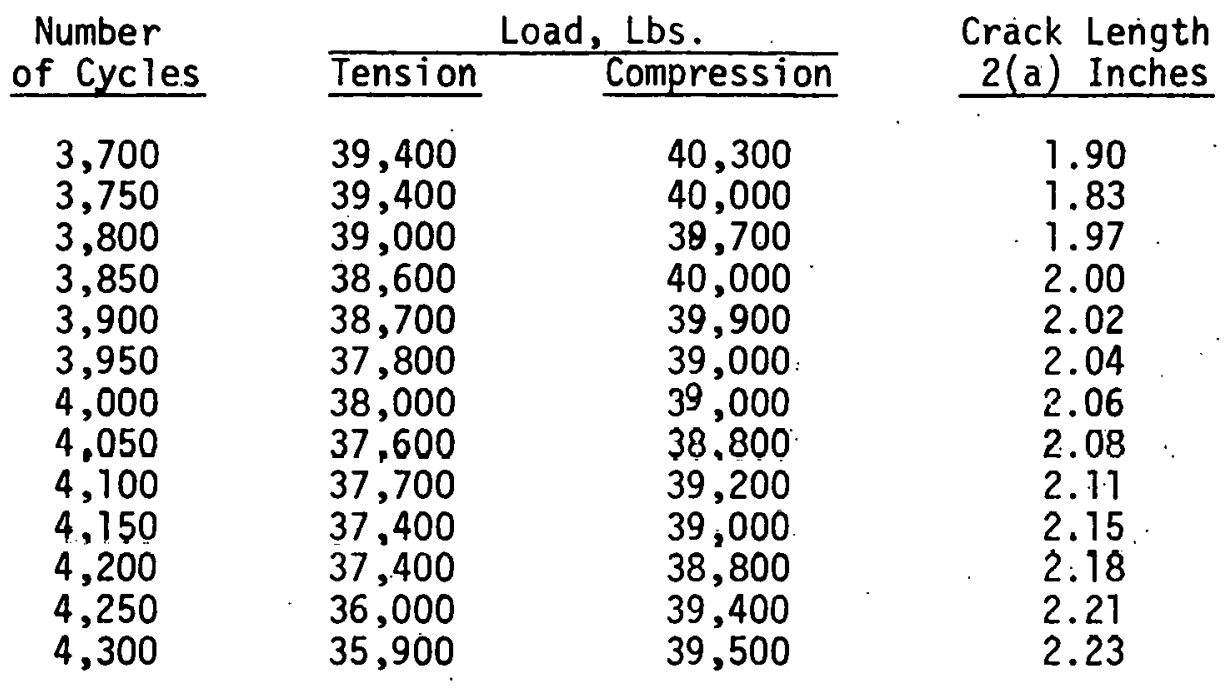


Spec: $H-1-A x i a l$

$2-1 / 4 \mathrm{Cr}$ - 1 Mo

RT

Total Strain Range: $1.0 \%$

\begin{tabular}{|c|c|c|c|}
\hline Number & \multicolumn{2}{|c|}{ Load, Lbs. } & \multirow{2}{*}{$\begin{array}{r}\text { Crack Length } \\
2(\mathrm{a}) \text { Inches }\end{array}$} \\
\hline of Cycles & Tension & Compression & \\
\hline 2 & 63,740 & 64,500 & .56 \\
\hline 10 & 62,250 & 61,800 & .69 \\
\hline 25 & 58,800 & 61,500 & 1.30 \\
\hline 50 & 47,250 & 51,300 & 2.15 \\
\hline 75 & 34,500 & 34,500 & 2.95 \\
\hline 100 & 26,550 & 27,300 & 3.50 \\
\hline 125 & 18,000 & 20,200 & 3.95 \\
\hline 135 & 9,750 & 12,750 & 4.28 \\
\hline
\end{tabular}


Spec: I-1-Axial

$2-1 / 4 \mathrm{Cr}-1 \mathrm{Mo}$

RT

Total Strain Range: $0.25 \%$

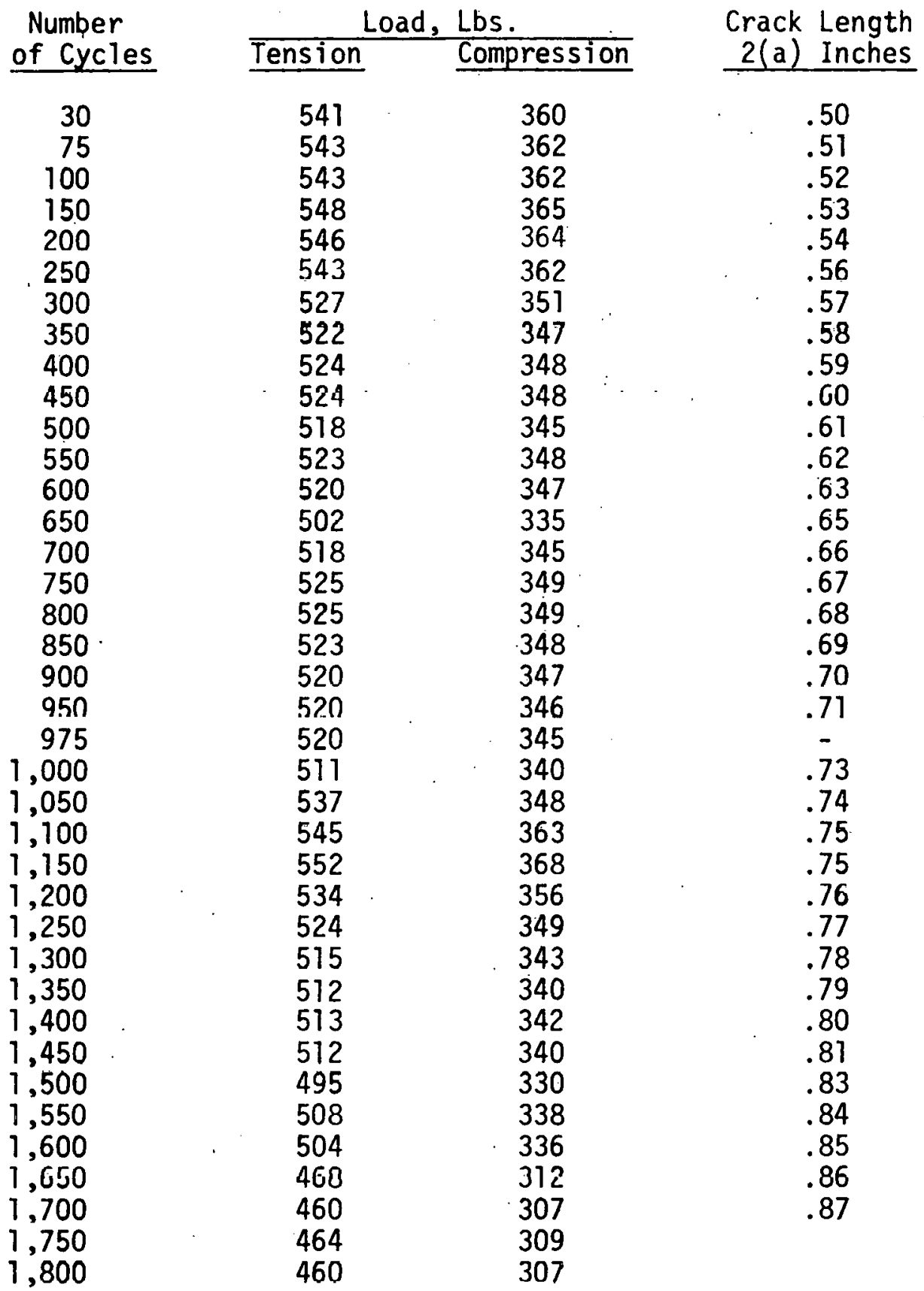


Spec: J1-J2-Axial

$2-1 / 4 \mathrm{Cr}-1 \mathrm{Mo}$

RT

Total Strain Range: $0.25 \%, 0.3 \%, 0.4 \%$

\begin{tabular}{|c|c|c|c|}
\hline $\begin{array}{c}\text { Number } \\
\text { of Cycles } \\
\end{array}$ & $\begin{array}{r}\text { Crack Length } \\
2 \text { (a) Inches } \\
\end{array}$ & $\begin{array}{c}\text { Number } \\
\text { of Cycles }\end{array}$ & $\begin{array}{l}\text { Crack Length } \\
2 \text { (a) Inches }\end{array}$ \\
\hline $\begin{array}{c}25 \\
100 \\
200 \\
300 \\
400 \\
500 \\
600 \\
700 \\
800 \\
900 \\
1,000 \\
1,015 \\
\text { Changed strain } \\
1,100 \\
1,200 \\
1,300 \\
1,400 \\
1,500 \\
1,600 \\
1,700 \\
1,900 \\
2.080 \\
\text { Changed strain } \\
2,100 \\
2,200 \\
2,400 \\
2,600 \\
2,700 \\
2,900\end{array}$ & 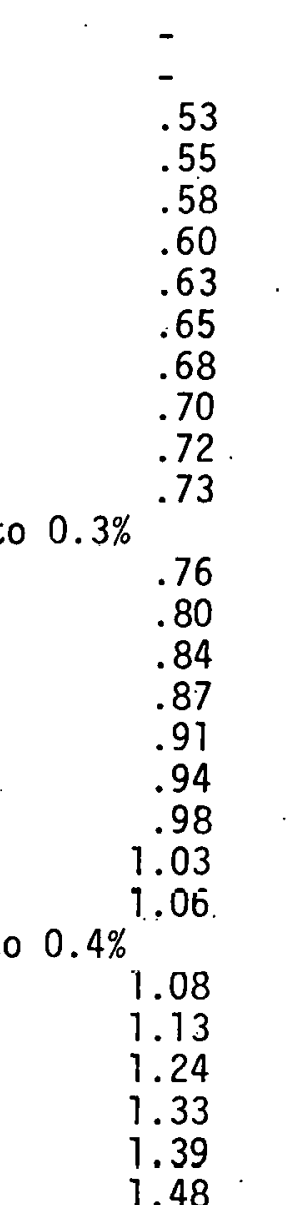 & $\begin{array}{l}3,300 \\
3,500 \\
3,700 \\
3,900 \\
4,100 \\
4,300 \\
4,500 \\
4,700 \\
5,000 \\
5,100 \\
5,300 \\
5,500 \\
5,700 \\
5,900 \\
6,100 \\
6,200\end{array}$ & $\begin{array}{l}1.69 \\
1.82 \\
1.90 \\
2.02 \\
2.11 \\
2.23 \\
2.35 \\
2.51 \\
2.77 \\
2.87 \\
3.06 \\
3.19 \\
3.31 \\
3.42 \\
3.52 \\
3.59\end{array}$ \\
\hline
\end{tabular}


Spec: $\mathrm{K}-1$ - Bendina

$2-1 / 4 \mathrm{Cr}$ - 1 Mo

RT

Tote. 1 Strain Range: $0.6 \%$

Number of Cycles

10

40

90

170

230

270

308

341

432

535

756

920

1,103

1,180

1,280

1,380

1,560

1,680

1,780

1,880

1,926

1,980

2,080

2,180

2,250

2,380

2,490

2,700

2,800

2,920

3,200

3,320

3,470

3,620 .

3,750

3,850

3,930

4,080

4,200

4,290

4,400

4,500

4,640

4,730

4,880

5,000
Load, Lbs.

Compression

630

880

885

890

875

875

880

890

895

900

895

890

$"$

"1

895

900

880

885

890

895

II

895

890

$"$

$"$

$"$

850

880

$"$

890

"I

880

885

880

885

885

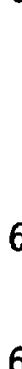

620

640

640

645

640

11

635

630

645

640

635

630

630

610

630

615

515

610

600

630

610

610

595

595

580

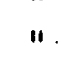

575

570

560 .

550

545
Crack Length 2(a) Inches

0

0

.26

.28

.29

.29

.29

.30

.32

.33

.35

.37

.41

.42

.43

.44

.47

.49

.51

.53

.54

.56

.58

.59

.67

.63

.66

.69

.72

.77

.79

.82

.86

.88

.91

.93

.96

.99

1.01

1.04

1.06

1.09

1.11

1.15

1.18 
Spec: K-1-Bending (cont'd.)

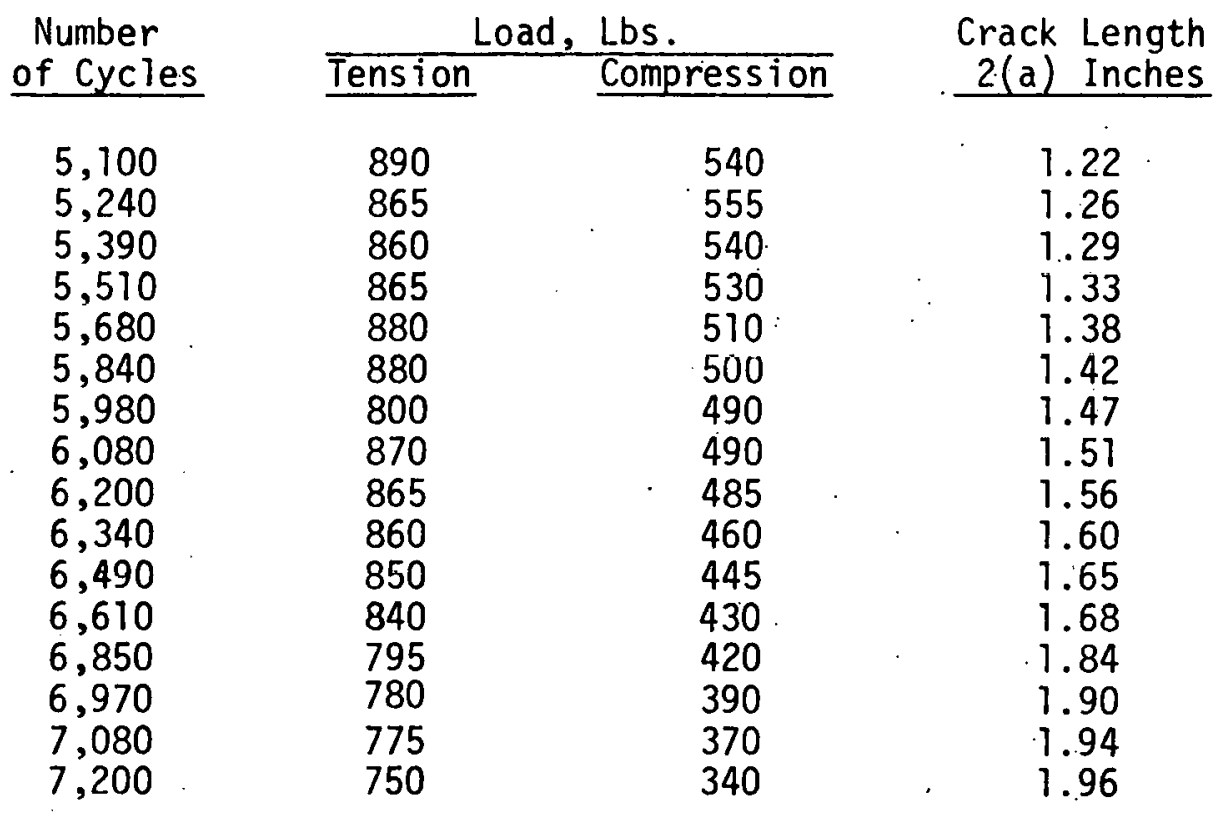


Spec: $L-1$-Bending

$2-1 / 4 \mathrm{Cr}$ - I Mo

GEAP-10181

RT

Total Stráin Range: $1.0 \%$

Moment Arm $=9.25^{\prime \prime}$

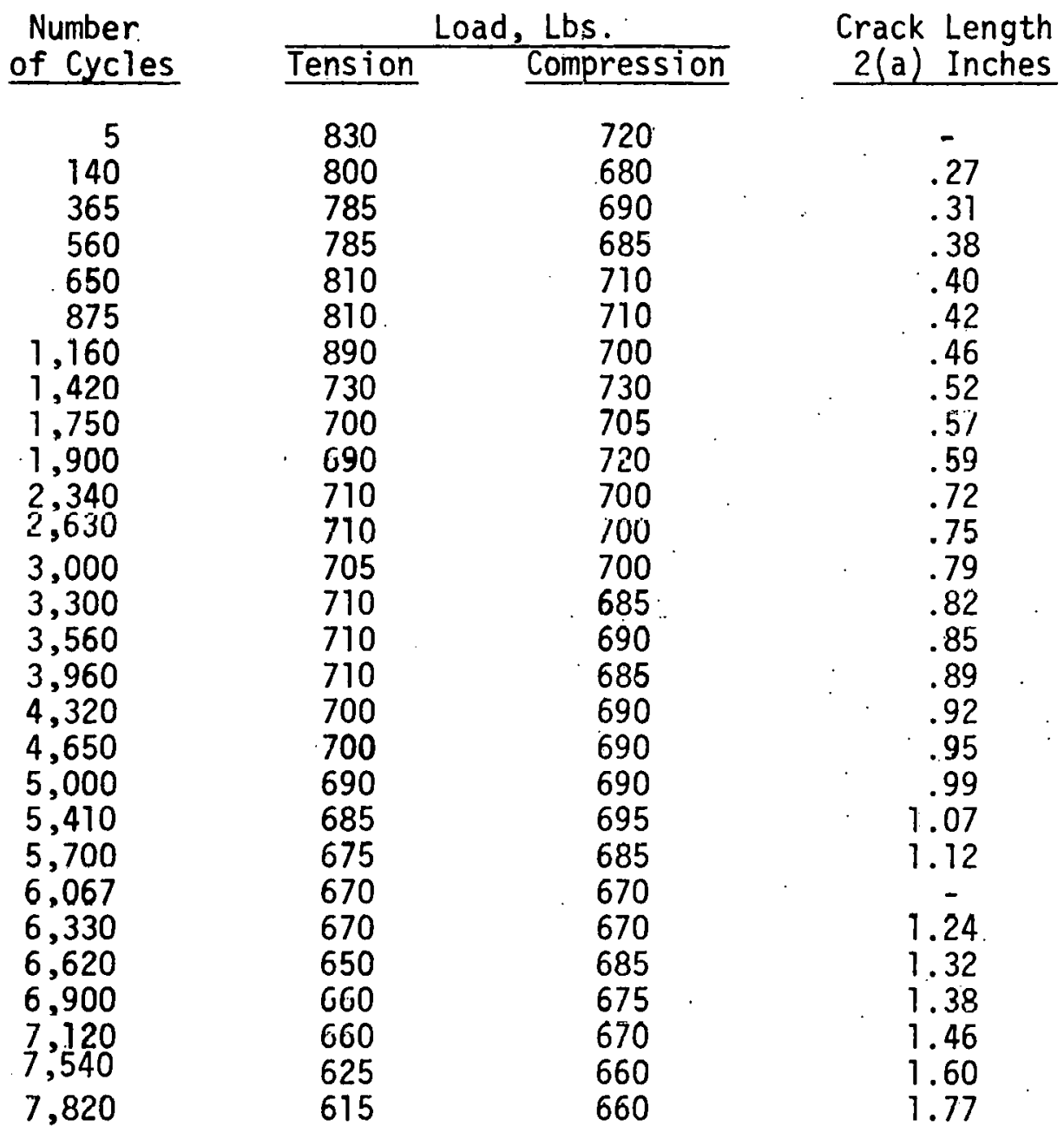


Spec: $M-1-B e n d i n g$

2-1/4 Cr - 1 Mo

$550^{\circ} \mathrm{F}$

Total Strain Range: $0.7 \%$

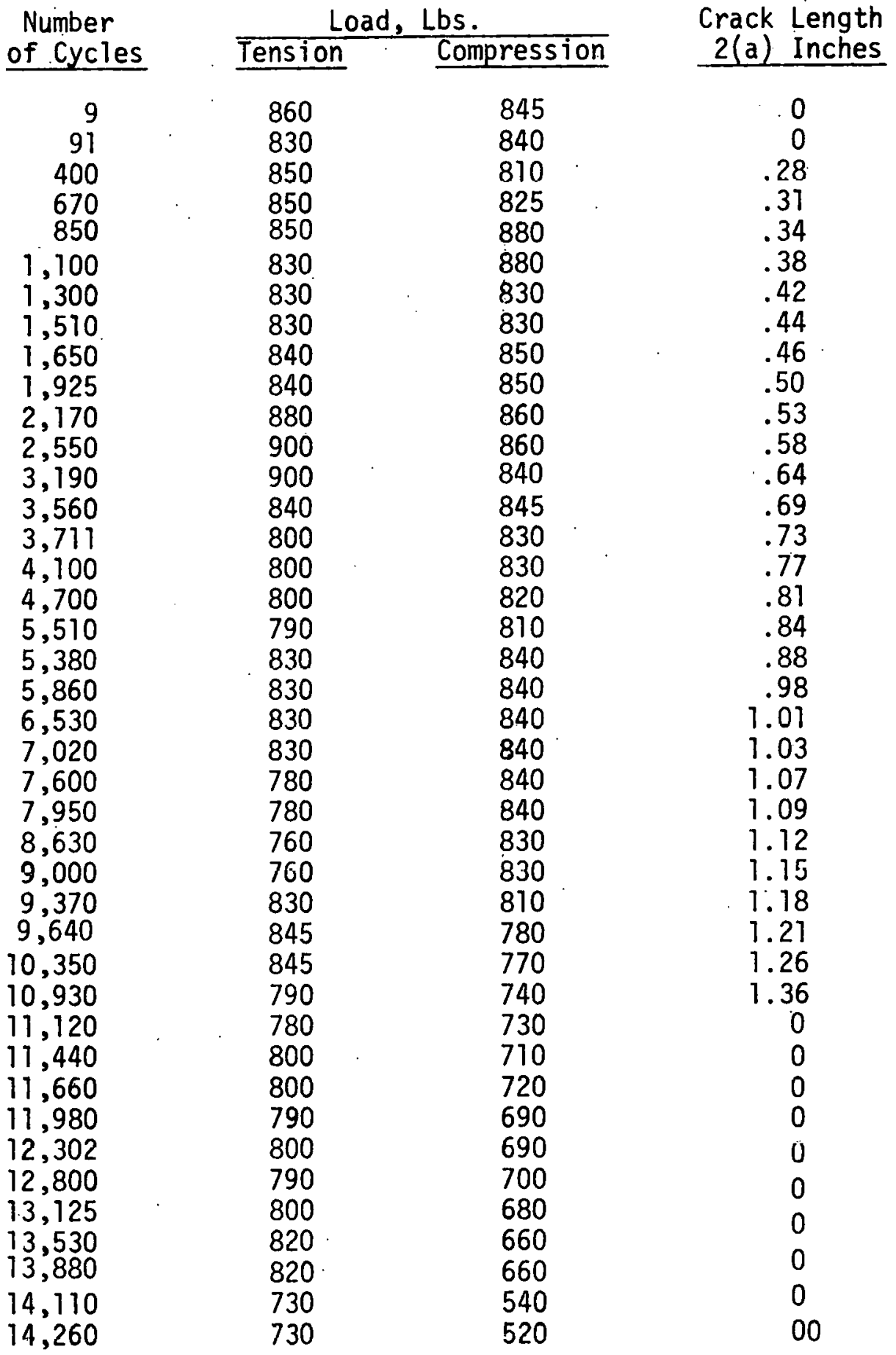




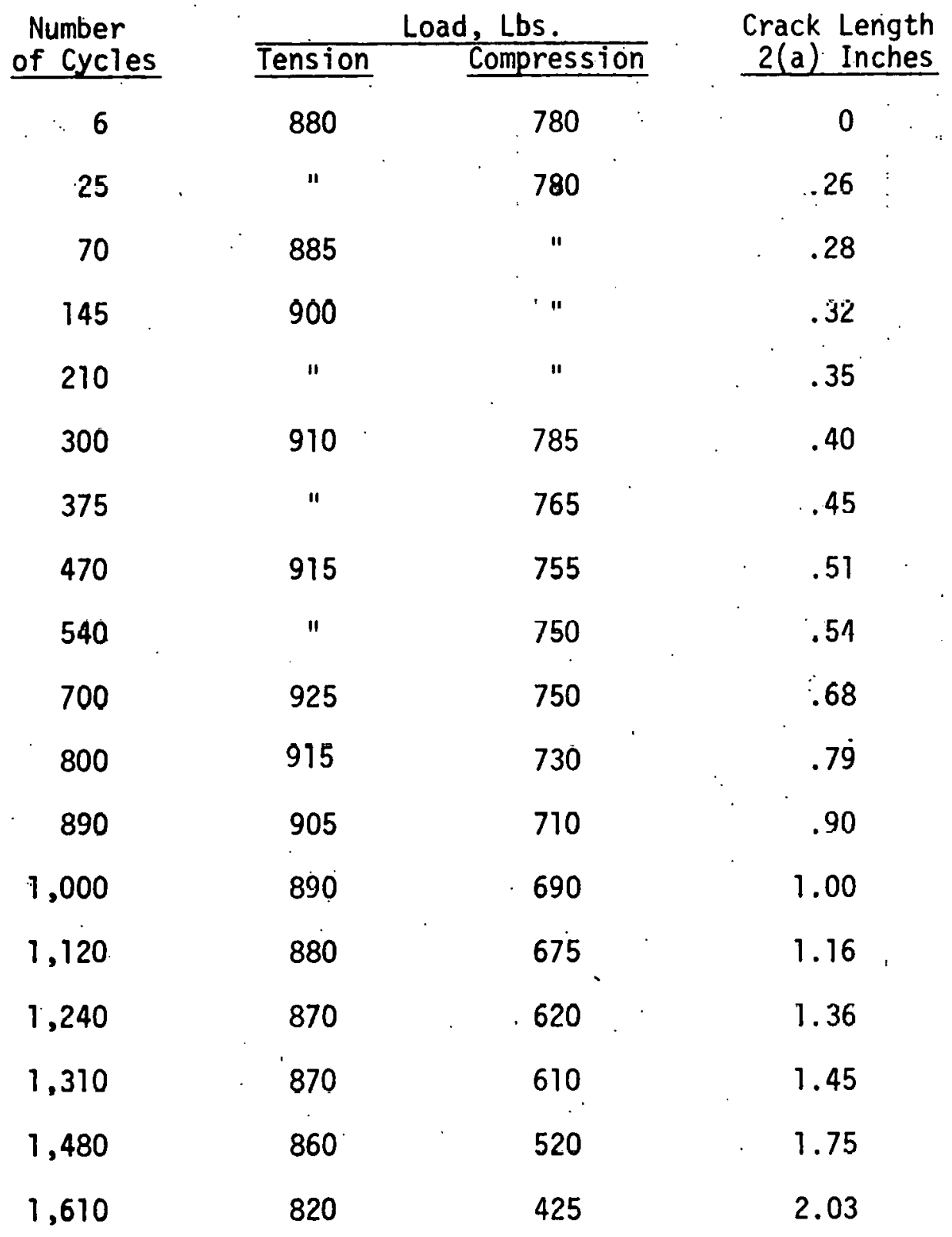


Spec: 0-1-Bending

$2-1 / 4 \mathrm{Cr}$ - 1 Mo

RT

Total Strain Range: $2.0 \%$

Moment Arm: 9.13"

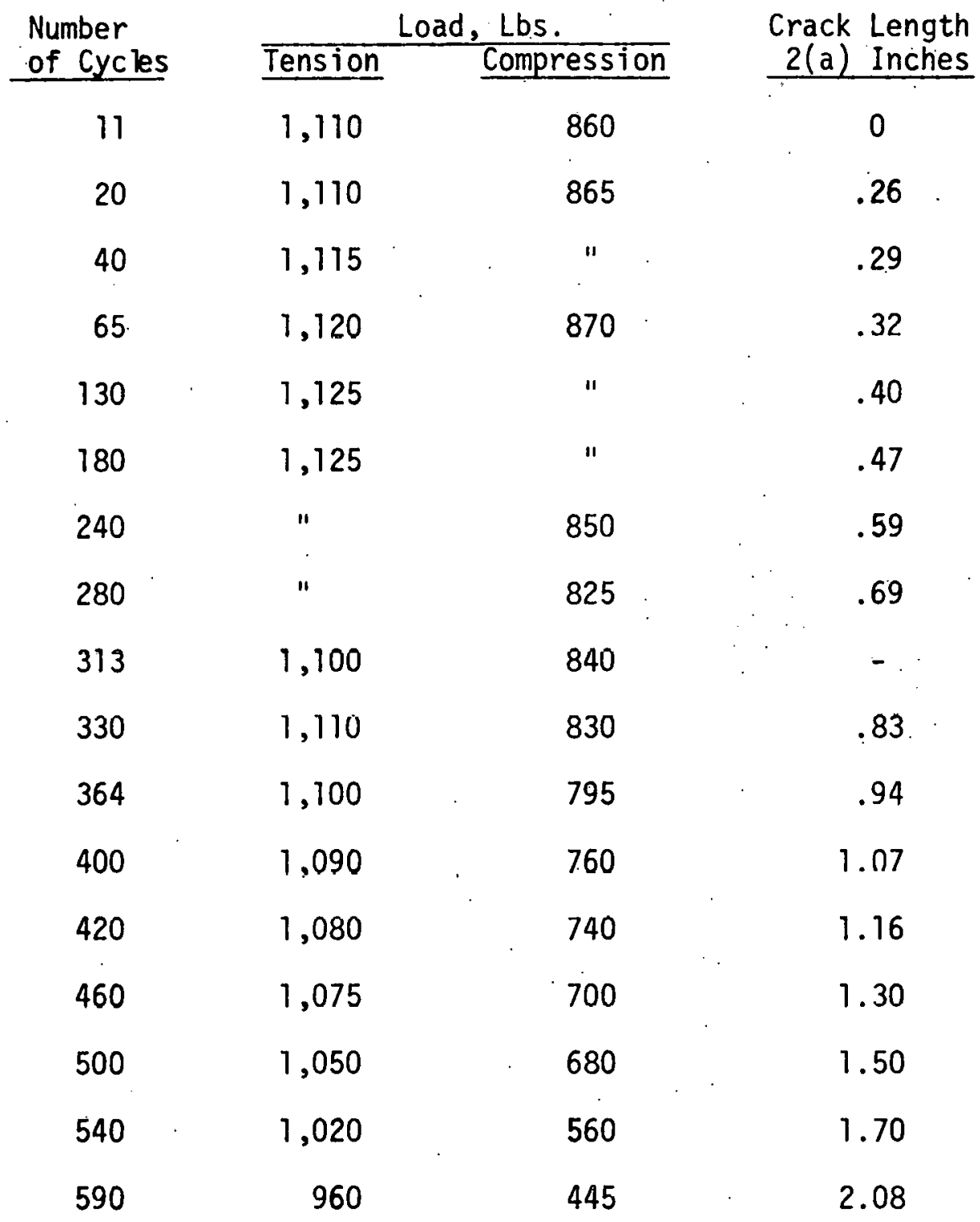


Spec: $P-1$-Bending

$2-1 / 4 \mathrm{Cr}-1 \mathrm{Mo}$

RT

Total Strain Range: $1.0 \%$

Moment Arm - 8.31"

\begin{tabular}{|c|c|c|c|c|}
\hline $\begin{array}{l}\text { Number } \\
\text { of Cycles }\end{array}$ & \multicolumn{2}{|c|}{ Load, Lbs. } & $\begin{array}{r}\text { Crac } \\
2(a\end{array}$ & $\begin{array}{l}k \text { Lengtr } \\
\text { Inches }\end{array}$ \\
\hline 350 & 890 & 690 & & .35 \\
\hline 500 & 870 & 710 & & .38 \\
\hline 700 & 890 & 700 & & .45 \\
\hline 900 & 900 & 680 & & .50 \\
\hline 1,000 & 900 & 675 & & .54 \\
\hline 1,200 & 900 & 670 & & .625 \\
\hline 1,300 & 895 & 660 & & .66 \\
\hline 1,500 & 890 & 640 & & .73 \\
\hline 1,700 & 885 & 680 & & .825 \\
\hline 1,900 & 895 & 615 & & .90 \\
\hline 2,000 & 885 & 620 & & .95 \\
\hline 2,200 & 885 & 600 & & 1.03 \\
\hline 2,400 & 890 & 555 & & 1.125 \\
\hline 2,500 & 890 & 555 & & 1.175 \\
\hline 2,700 & 890 & 540 & & 1.30 \\
\hline 2,900 & 885 & 530 & & 1.40 \\
\hline 3,000 & 870 & 490 & & 1.45 \\
\hline 3,100 & 865 & 480 & & 1.50 \\
\hline 3,400 & 810 & 435 & . & 1.63 \\
\hline
\end{tabular}


Spec: Q-1-Axial

2-1/4 Cr - 1 Mo

RT

Total. Strain Range: $0.4 \%$

PTC - 0.8" Thick

\begin{tabular}{|c|c|c|c|}
\hline $\begin{array}{l}\text { Number } \\
\text { of Cycles }\end{array}$ & $\begin{array}{r}\text { Crack Length } \\
2(a) \text { Inches }\end{array}$ & $\begin{array}{l}\text { Number } \\
\text { of Cycles }\end{array}$ & $\begin{array}{r}\text { Crack Length } \\
2(a) \text { Inches }\end{array}$ \\
\hline $\begin{array}{r}11 \\
273 \\
356 \\
650 \\
1,400 \\
1,700 \\
1,950 \\
1,989 \\
2,250 \\
2,350 \\
2,750 \\
2,940 \\
2,962 \\
3,170 \\
3,360 \\
3,640 \\
3,930 \\
4,180 \\
4,646 \\
4,710 \\
4,770 \\
4,890 \\
5,050 \\
5,200 \\
5,281 \\
5,400 \\
5,420 \\
5,500 \\
5,620 \\
5,770 \\
5,790 \\
5,850 \\
6,220 \\
6,400 \\
6,650 \\
6,850 \\
6,884 \\
6,960 \\
7,220 \\
7,420\end{array}$ & $\begin{array}{c}0 \\
.550 \\
0.59 \text { down to } 0.2 \% \\
.600 \\
.60 \\
.63 \\
.65 \\
\text { up to } 0.4 \% \\
0.750 \text { down to } 0.05 \% \\
.77 \\
.77 \\
.78 \\
- \\
.78 \\
0.78 \text { up to } 0.4 \% \\
1.06 \text { down to } 0.05 \% \\
1.06 \\
1.06 \\
1.06 \text { up to } 0.4 \% \\
1.17 \\
1.27 \text { down to } 0.075 \% \\
1.27 \\
1.27 \\
1.28 \\
- \\
1.30 \text { down to } 0.06 \% \\
1.30 \\
1.30 \\
1.31 \\
1.31 \text { up to } 0.4 \% \\
1.40 \\
1.51 \text { down to } 0.06 \% \\
1.51 \\
1.51 \\
1.52 \\
1.52 \text { up to } 0.4 \% \\
1.70 \\
1.90 \text { down to } 0.06 \% \\
1.90 \\
1.90 \\
1.90 \\
1\end{array}$ & $\begin{array}{l}7,580 \\
7,960 \\
8,000 \\
8,040 \\
8,300 \\
8,610 \\
9,045 \\
9,066 \\
9,100 \\
9,166 \\
9,500 \\
9,750 \\
10,162 \\
10,200 \\
10,236 \\
10,275 \\
10,300 \\
10,330 \\
10,440 \\
10,725 \\
11,409 \\
11,436 \\
11,480 \\
11,500\end{array}$ & $\begin{array}{c}1.90 \\
1.90 \text { up to } 0.4 \% \\
1.96 \\
2.10 \text { down to } 0.06 \% \\
2.12 \\
2.13 \\
2.15 \text { up to } 0.4 \% \\
2.30 \\
2.40 \\
2.54 \text { down to } 0.06 \% \\
2.54 \\
2.55 \\
2.55 \text { up to } 0.4 \% \\
2.67 \\
2.74 \\
2.82 \\
2.90 \\
2.95 \text { down to } 0.06 \% \\
2.95 \\
2.96 \text { up to } 0.4 \% \\
2.96 \\
3.04 \\
3.10 \\
3.13\end{array}$ \\
\hline
\end{tabular}


Spec: R-1-Axial

2-1/4 Cr - 1 Mo

RT

Total Strain Range: $0.4 \%$

PTC - 0.8" Thick

\begin{tabular}{|c|c|c|c|}
\hline $\begin{array}{l}\text { Number } \\
\text { of Cycles }\end{array}$ & $\begin{array}{r}\text { Crack Length } \\
2 \text { (a) Inches }\end{array}$ & $\begin{array}{l}\text { Number } \\
\text { of Cycles }\end{array}$ & $\begin{array}{l}\text { Crack Length } \\
2 \text { (a) Inches }\end{array}$ \\
\hline $\begin{array}{r}7 \\
50 \\
100 \\
765 \\
895 \\
959 \\
1,080 \\
1,330 \\
1,986 \\
2,026 \\
2,095 \\
2,178 \\
2,260 \\
2,470 \\
2,640 \\
3,050 \\
3,195 \\
3,250 \\
3,340 \\
3,420 \\
3,720 \\
3,965 \\
4,050 \\
4,642 \\
4,665 \\
4,680 \\
4,900 \\
5,095\end{array}$ & $\begin{array}{c}0 \\
0 \\
0 \\
0 \\
.55 \\
0.60 \text { down to } 0.06 \% \\
.60 \\
.61 \\
\text { to } 0.04 \% \\
.66 \\
.70 \\
0.61 \text { up } \\
0.80 \text { down to } 0.06 \% \\
.80 \\
.80 \\
.80 \\
.80 \\
0.80 \text { up to } 0.4 \% \\
.89 \\
1.05 \\
1.34 \text { down to } 0.06 \% \\
1.36 \\
7.40 \\
1.40 \text { down to } 0.05 \% \\
1.60 \\
1.72 \\
1.80 \text { down to } 0.05 \% \\
1.80 \\
1.81\end{array}$ & $\begin{array}{l}5,200 \\
5,273 \\
5,696 \\
5,715 \\
5,728 \\
5,740 \\
5,755 \\
6,130 \\
6,620 \\
6,700 \\
6,770 \\
6,780 \\
6,790 \\
7,100 \\
7,430 \\
7,580 \\
7,795 \\
7,802 \\
7,808\end{array}$ & $\begin{array}{c}1.87 \\
1.88 \text { down to } 0.04 \% \\
1.90 \text { up to } 0.04 \% \\
2.05 \\
2.12 \\
2.40 \\
2.39 \text { down to } 0.04 \% \\
2.40 \\
2.40 \\
2.40 \\
2.46 \text { up to } 0.4 \% \\
2.65 \\
2.89 \\
2.90 \\
2.95 \\
2.95 \\
2.98 \text { up to } 0.04 \% \\
3.20 \\
3.40\end{array}$ \\
\hline
\end{tabular}


Spec: S-1-Axial

2-1/4 Cr - 1 Mo

RT

Total Strain Range: $0.4 \%$

PTC 2" $20.2 "$

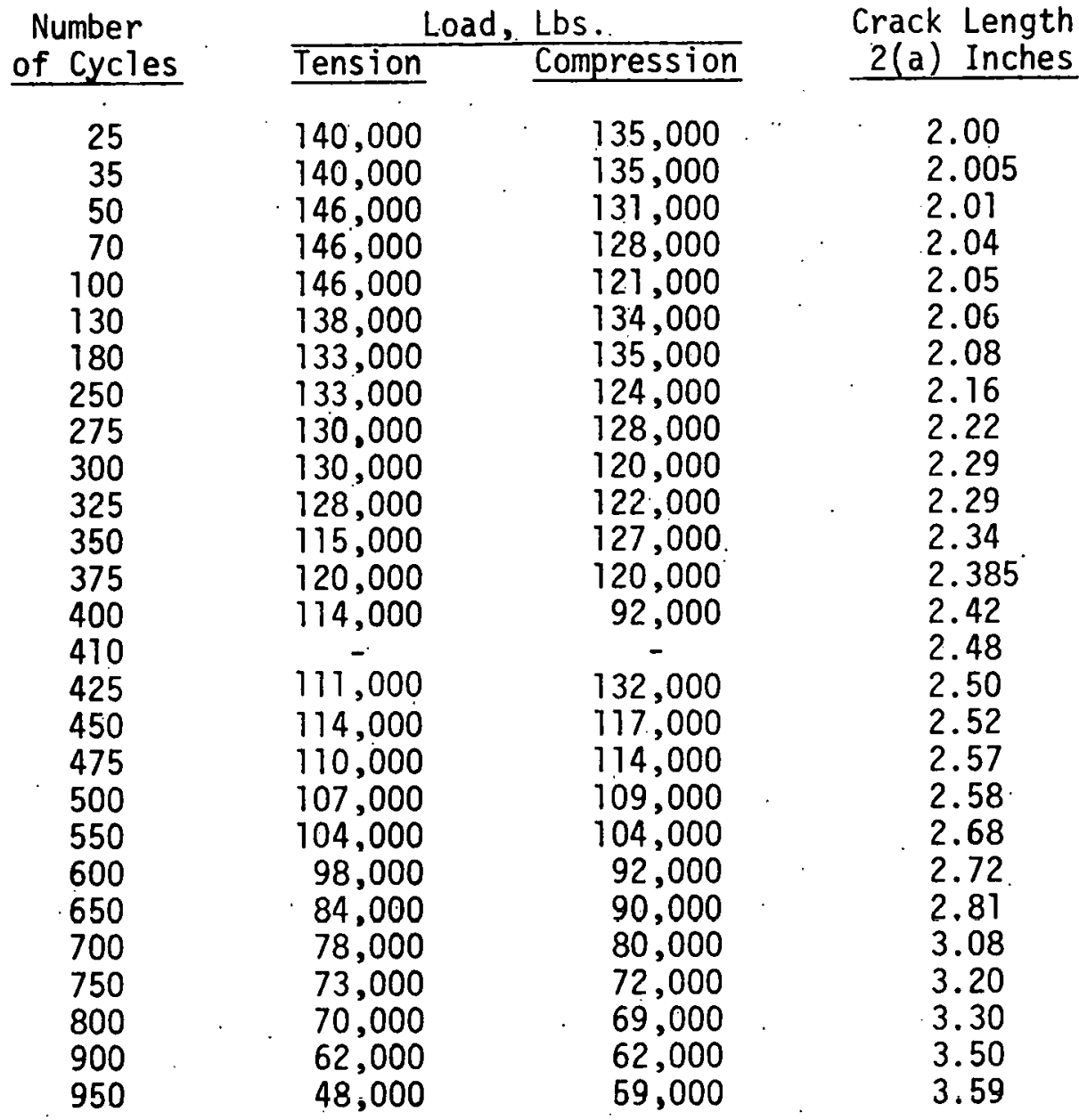


RT

Total Strain Range: $0.4 \%$

PTC 1.0" $\times 0.2^{\prime \prime}$

\begin{tabular}{|c|c|c|c|}
\hline $\begin{array}{l}\text { Number } \\
\text { of Cycles }\end{array}$ & $\frac{\mathrm{LO}}{\mathrm{T}}$ & bs. & Crack Length \\
\hline & 143.000 & 146.000 & \\
\hline 70 & 144,000 & $\begin{array}{l}146,000 \\
148,000\end{array}$ & 0 \\
\hline 100 & 148,000 & 147,000 & $\begin{array}{l}0 \\
0\end{array}$ \\
\hline 300 & 151,000 & 146,000 & 0 \\
\hline 415 & 148,100 & 148,000 & 1.07 \\
\hline 450 & 146,000 & 146,000 & 1.09 \\
\hline 500 & 148,000 & 145,000 & 1.11 \\
\hline 550 & 148,000 & 147,000 & 1.13 \\
\hline 595 & 144,000 & 145,000 & 1.15 \\
\hline 650 & 145,000 & 141,000 & 1.18 \\
\hline 750 & 144,000 & 141,000 & 1.26 \\
\hline 850 & 142,000 & 142,000 & 1.41 \\
\hline 950 & 138,000 & 139,000 & 1.53 \\
\hline 1,050 & 135,000 & 134,000 & 1.67 \\
\hline 1,150 & 126,000 & 126,000 & 1.88 \\
\hline 1,250 & 109,000 & 111,000 & 2.27 \\
\hline 1,300 & 102,000 & 104,000 & 2.41 \\
\hline 1,350 & 85,000 & 80,000 & 2.81 \\
\hline $\begin{array}{l}1,400 \\
1,450\end{array}$ & 79,000 & 73,000 & 2.91 \\
\hline $\begin{array}{l}1,450 \\
1,550\end{array}$ & $\begin{array}{l}74,000 \\
70.000\end{array}$ & $\begin{array}{l}72,000 \\
68,000\end{array}$ & $\begin{array}{l}2.99 \\
3.14\end{array}$ \\
\hline 1,650 & 62,000 & $\begin{array}{l}68,000 \\
59,000\end{array}$ & $\begin{array}{l}3.14 \\
3.31\end{array}$ \\
\hline 1,750 & 58,000 & 56,000 & 3.43 \\
\hline 1,850 & 52,000 & 55,000 & 3.58 \\
\hline 1,900 & 50,000 & 52,000 & 3.62 \\
\hline $\begin{array}{l}7,950 \\
2,025\end{array}$ & $\begin{array}{l}46,000 \\
42.000\end{array}$ & 50,000 & 3.67 \\
\hline & & 43,000 & 3.76 \\
\hline
\end{tabular}


Spec: U-1-Axial

$2-1 / 4 \mathrm{Cr}-1 \mathrm{Mo}$

RT

Total Strain Range, $0.4 \%$

Spec FS

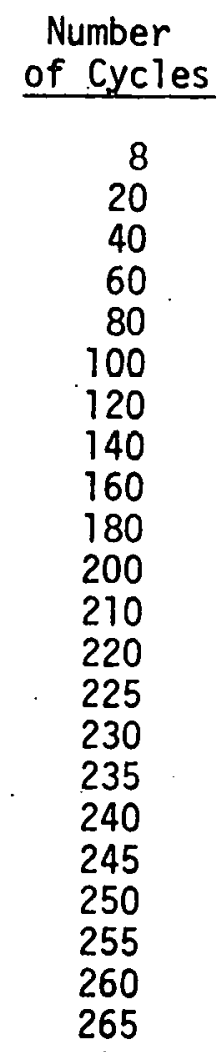

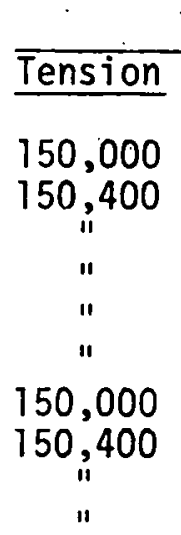

150,600

152,000

1

145,000

134,800

118,400

99,000

114,000

108,800

100,400

99,000
Load, Lbs.

Compression

145,000

144,000

144,000

143,600

142,800

142,400

140,600

140,600

140,600

138,800

124,200

126,000

126,400

134,000

136,800

132,200

128,000

88,600

130,000

133,600

132,400

134,600
Crack Length

2(a) Inches

0

.01

.02

.03

.04

.05

.05

.06

.07

.07

.08

.10

.12

.15

.22

.28

.30

.32

.34

.38

.43

.52 
Spec: $\quad V-i-B e n d i n g$

A-212B

$550^{\circ} \mathrm{F}$

Total Strain Range: $1.0 \%$

\begin{tabular}{cc}
$\begin{array}{c}\text { Number } \\
\text { of Cycles }\end{array}$ & $\begin{array}{r}\text { Crack Length } \\
2(a)\end{array}$ \\
\cline { 1 - 2 } 1,250 & .475 \\
1,900 & .59 \\
2,650 & .75 \\
3,150 & .80 \\
3,950 & .87 \\
5,100 & 1.0 \\
5,800 & 1.75 \\
6,350 & 1.23 \\
6,650 & 1.31 \\
7,250 & 1.48 \\
7,850 & 1.675
\end{tabular}


Spec: A-2-Axial

$A-212 B$

RT

Total Strain Range: $0.25 \%$

\begin{tabular}{|c|c|c|c|}
\hline Number & & Lbs. & Crack Length \\
\hline of Cycles & Tension & Compression & 2(a) Inches \\
\hline 22 & 60,000 & 80,000 & .83 \\
\hline 39 & 54,000 & 75,000 & .99 \\
\hline 81 & 50,250 & 78,000 & 1.30 \\
\hline 99 & 46,500 & 72,000 & 1.46 \\
\hline 135 & 47,250 & 67,500 & 1.90 \\
\hline 140. & 41,000 & 61,500 & 1.94 \\
\hline 171 & 32,500 & 62,000 & 2.16 \\
\hline 219. & 35,200 & $61,000$. & 2.43 \\
\hline 270 & 32,300 & 63,000 & 2.70 \\
\hline 291 & 30,800 & 60,800 & 2.77 \\
\hline 321 & 29,300 & 60,000 & 2.90 \\
\hline 339 & 28,100 & 57,800 & 2.97 \\
\hline 405 & 24,700 & 59.200 & 3.25 \\
\hline 444 & 21,800 & 60,700 & 3.43 \\
\hline 477 & 19,500 & 58,500 & 3.59 \\
\hline 537 & 16,500 & 57,700 & 3.83 \\
\hline 573 & 15,000 & 57,700 & 3.93 \\
\hline 612 & 12,700 & 57,200 & 3.98 \\
\hline
\end{tabular}


Spec: B-2-Axial

$A-212 B$

RT

Total Strain Range: $0.75 \%$

\begin{tabular}{|c|c|c|c|}
\hline \multirow{2}{*}{$\begin{array}{l}\text { Number } \\
\text { of Cycles }\end{array}$} & \multicolumn{2}{|c|}{ Load, Lbs. } & \multirow{2}{*}{$\begin{array}{r}\text { Crack Length } \\
2(a) \text { Inches }\end{array}$} \\
\hline & Tension & Compression & \\
\hline 1 & 56,700 & 58.5 & .50 \\
\hline 3 & 53,200 & 57.9 & .62 \\
\hline 10 & 49,200 & 52.6 & 1.20 \\
\hline 25 & 42,750 & 48.6 & 1.95 \\
\hline 50 & 28,800 & 37.5 & 2.88 \\
\hline 60 & 22,200 & 29.4 & 3.36 \\
\hline 70 & 18,300 & 24.3 & 3.70 \\
\hline 75 & 15,000 & 22.6 & 3.90 \\
\hline 85 & 13,200 & 20.7 & 4.15 \\
\hline 90 & 10,200 & 18.8 & 4.28 \\
\hline 95 & 9,300 & 15.0 & 4.45 \\
\hline
\end{tabular}


Spec: C-2-Axial

A-212B

RT

Total Strain Range: $0.3 \%$

\begin{tabular}{|c|c|c|c|c|}
\hline $\begin{array}{l}\text { Number } \\
\text { of Cycles }\end{array}$ & Tension & , Loms. & $\begin{array}{c}\text { Crack } \\
2(a)\end{array}$ & $\begin{array}{l}\text { Length } \\
\text { Inches }\end{array}$ \\
\hline 200 & 37,900 & 25,200 & & 1.71 \\
\hline 250 & 37,300 & 24,800 & & 1.83 \\
\hline 300 & 37,100 & 24,700 & & 1.91 \\
\hline 350 & - & - & & 1.99 \\
\hline 400 & 35,100 & 23,400 & & 2.08 \\
\hline 450 & - & - & & 2.15 \\
\hline 500 & 32,700 & 21,800 & & 2.22 \\
\hline 550 & - & - & & 2.29 \\
\hline 600 & 31,800 & 21,200 & & 2.36 \\
\hline 650 & - & - & & 2.42 \\
\hline 700 & - & - & & 2.49 \\
\hline 750 & 30,000 & 20,000 & & 2.54 \\
\hline 800 & 29,000 & 19,300 & & 2.60 \\
\hline 850 & 29,400 & - & & 2.66 \\
\hline 900 & 28,400 & - & & 2.73 \\
\hline
\end{tabular}


Spec: $D-2-A x i a 1$

$A-212 B$

RT

Total Strain Range: $0.25 \%$

Number of Cycles

253

275

300

325

350

375

400

575

625

675

725

750

800

825

900

925

975

1,000

1,025

1,050

1,100

1,125

1,175

$i, 200$

1,250

1,300

1,350

1,400

1,450

1,500
Load, Lbs.

Tension Compression

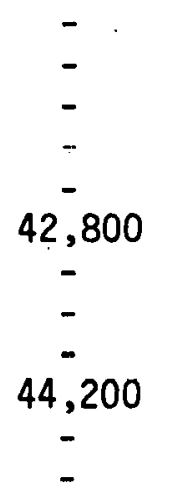

45,800

45,800
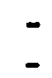

-

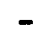

-

$47^{-}, 000$

$-$

$-$

$-$

43,200

$-$

-
Crack Length

2(a) Inches

.52

.53

.54

.55

.56

.57

.58

.60

.61

.62

.63

.64

.65

.66

.67

.68

.69

.70

.71

.72

.73

.74

.75

.76

.77

.78

.79

.80

.81

.82 
Spec: E-2-Axial

$A-212 B$

RT

Total Strain Range: $0.350 \%$

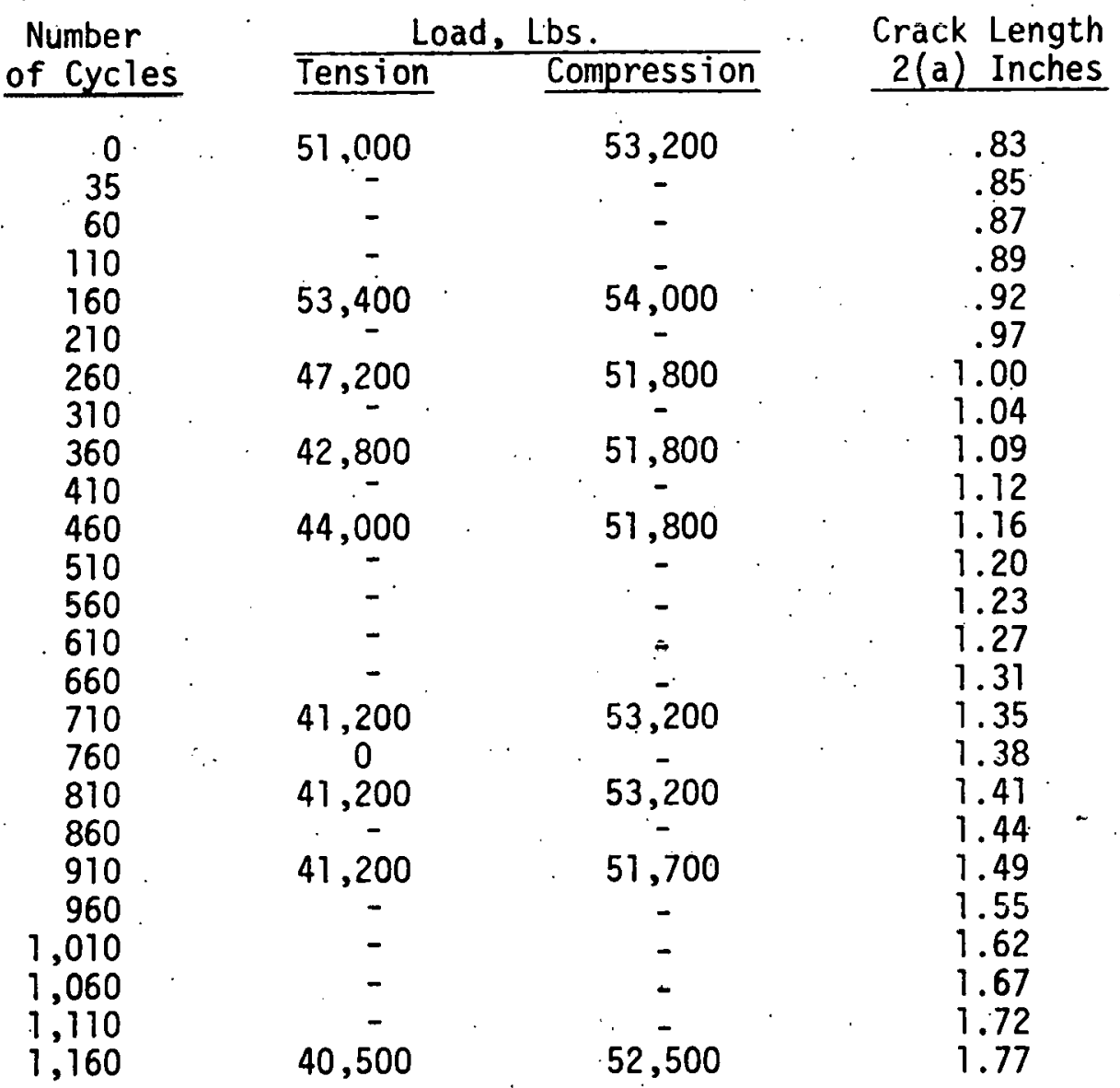


Spec: F-2-Axial

$A-212 B$

RT

Total Strain Range: 1.0\%

\begin{tabular}{|c|c|c|c|}
\hline Number & \multicolumn{2}{|c|}{ Load, Lbs. } & Crack Length \\
\hline of Cycles & Tension & Compression & 2(a) Inches \\
\hline 25 & 53,300 & 76,500 & 2.1 \\
\hline 34 & 66.500 & 73.500 & 2.3 \\
\hline 41 & 41,300 & 72,600 & 2.5 \\
\hline 50 & 36,000 & 72,000 & 3.0 \\
\hline 59 & 31,500 & 72,000 & 3.25 \\
\hline 69 & 27,000 & 70,500 & 3.60 \\
\hline 80 & 21,800 & 69,600 & 3.85 \\
\hline 90 & 16,500 & 70,500 & 4.30 \\
\hline 95. & - & - & - \\
\hline
\end{tabular}


Spec: G-2-Axial

$A-212 B$

$\mathrm{R}:$

Total Strain Range: $1.0 \%$

\begin{tabular}{|c|c|c|c|}
\hline Number & & Lbs. & $\begin{array}{l}\text { Crack Length } \\
2(a) \text { Inches }\end{array}$ \\
\hline & Tension & Compression & \\
\hline 0 & 70,000 & 0 & 0.5 \\
\hline 10 & 0 & & 0.63 \\
\hline 20 & 68,000 & & 0.80 \\
\hline 30 & 65,000 & . & 0.90 \\
\hline 40 & 62,000 & ? & 1.00 \\
\hline 50 & 58,000 & & 1.04 \\
\hline 60 & 56,000 & & 1.12 \\
\hline 70 & 54,000 & . & 1.20 \\
\hline 80 & 53,000 & . & 1.30 \\
\hline 90 & 52,000 & & 1.40 \\
\hline 100 & 50,000 & & 1.46 \\
\hline 110 & 49,000 & & 1.60 \\
\hline 120 & 47,000 & & 1.70 \\
\hline 130 & 46,000 & & 1.85 \\
\hline 140 & 41,000 & & 1.90 \\
\hline 150 & 0 & & 1.93 \\
\hline 160 & 0 & & 2.09 \\
\hline 170 & 33,000 & & 2.19 \\
\hline 180 & 0 & $\downarrow$ & 2.28 \\
\hline
\end{tabular}


Spec: $\quad H-2-B e n d i n g$

\section{A-212B}

RT

Total Strain Range, $0.6 \%$

Moment Arm = ND

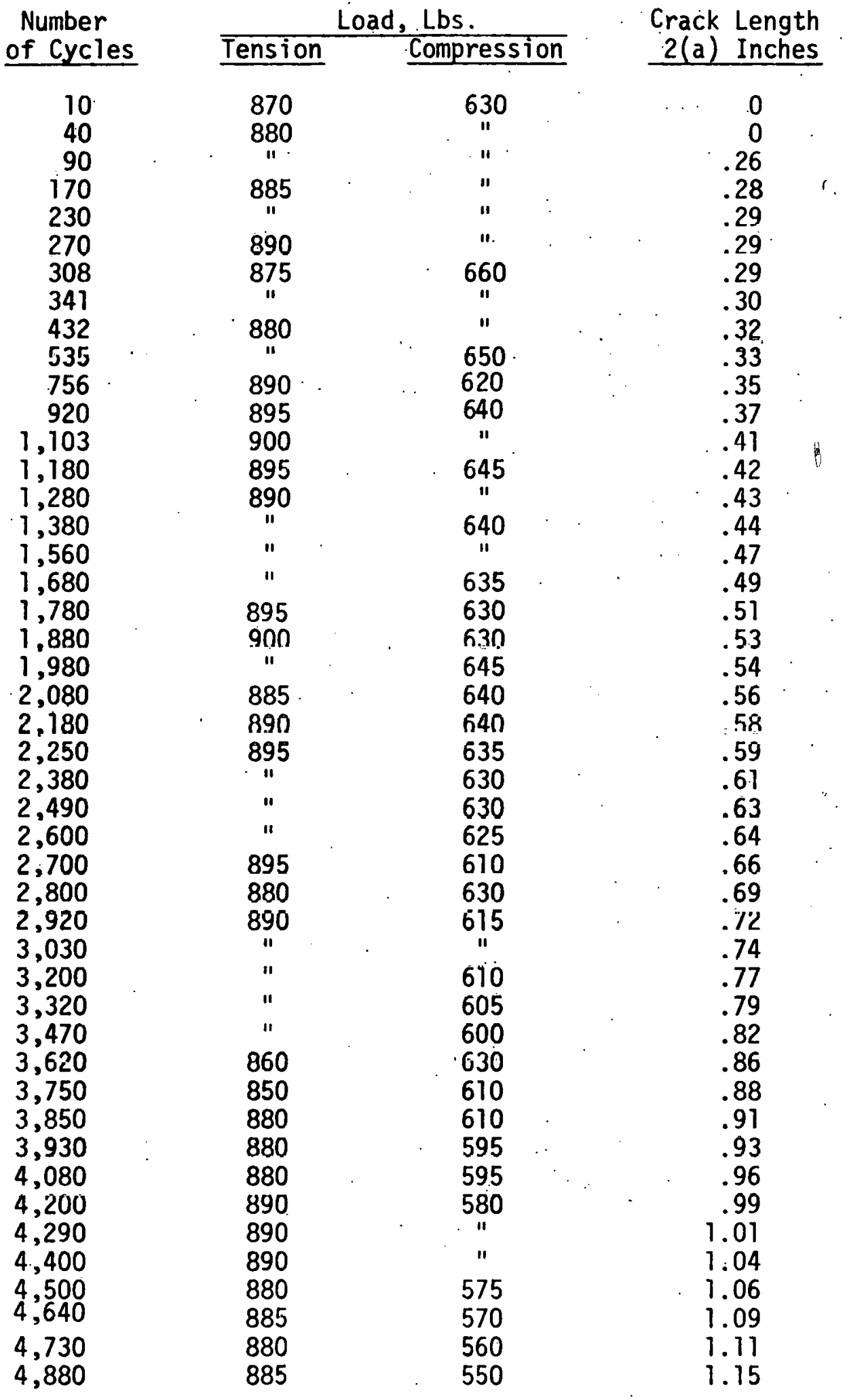

(cont'd.) 
Spec: H-2-Bending (cont'd.)

\begin{tabular}{|c|c|c|c|c|}
\hline $\begin{array}{l}\text { Number } \\
\text { of Cycles }\end{array}$ & Tension & $\begin{array}{l}\text { Lbs. } \\
\text { Compression }\end{array}$ & $\begin{array}{r}\text { Crack } \\
2(a) \\
\end{array}$ & $\begin{array}{l}\text { Length } \\
\text { Inches }\end{array}$ \\
\hline $\begin{array}{l}5,000 \\
5,110 \\
5,240 \\
5,390 \\
5,510 \\
5,680 \\
5,840 \\
5,980 \\
6,080 \\
6,200 \\
6,340 \\
6,490 \\
6,610 \\
6,610 \\
6,710\end{array}$ & $\begin{array}{l}885 \\
890 \\
865 \\
860 \\
865 \\
880 \\
880 \\
880 \\
870 \\
865 \\
860 \\
850 \\
840 \\
840 \\
-\end{array}$ & $\begin{array}{l}545 \\
540 \\
555 \\
540 \\
530 \\
510 \\
500 \\
490 \\
.11 \\
485 \\
460 \\
445 \\
430 \\
430 \\
-\end{array}$ & . & $\begin{array}{l}1.18 \\
1.22 \\
1.26 \\
1.29 \\
1.33 \\
1.38 \\
1.42 \\
1.47 \\
1.51 \\
1.56 \\
1.60 \\
1.65 \\
1.65 \\
1.68 \\
-\end{array}$ \\
\hline
\end{tabular}


Spec: i-z-Berding

$A-212 B$

RT

Total Strain Range: $1.0 \%$

Moment Arm $=8.44^{\prime \prime}$

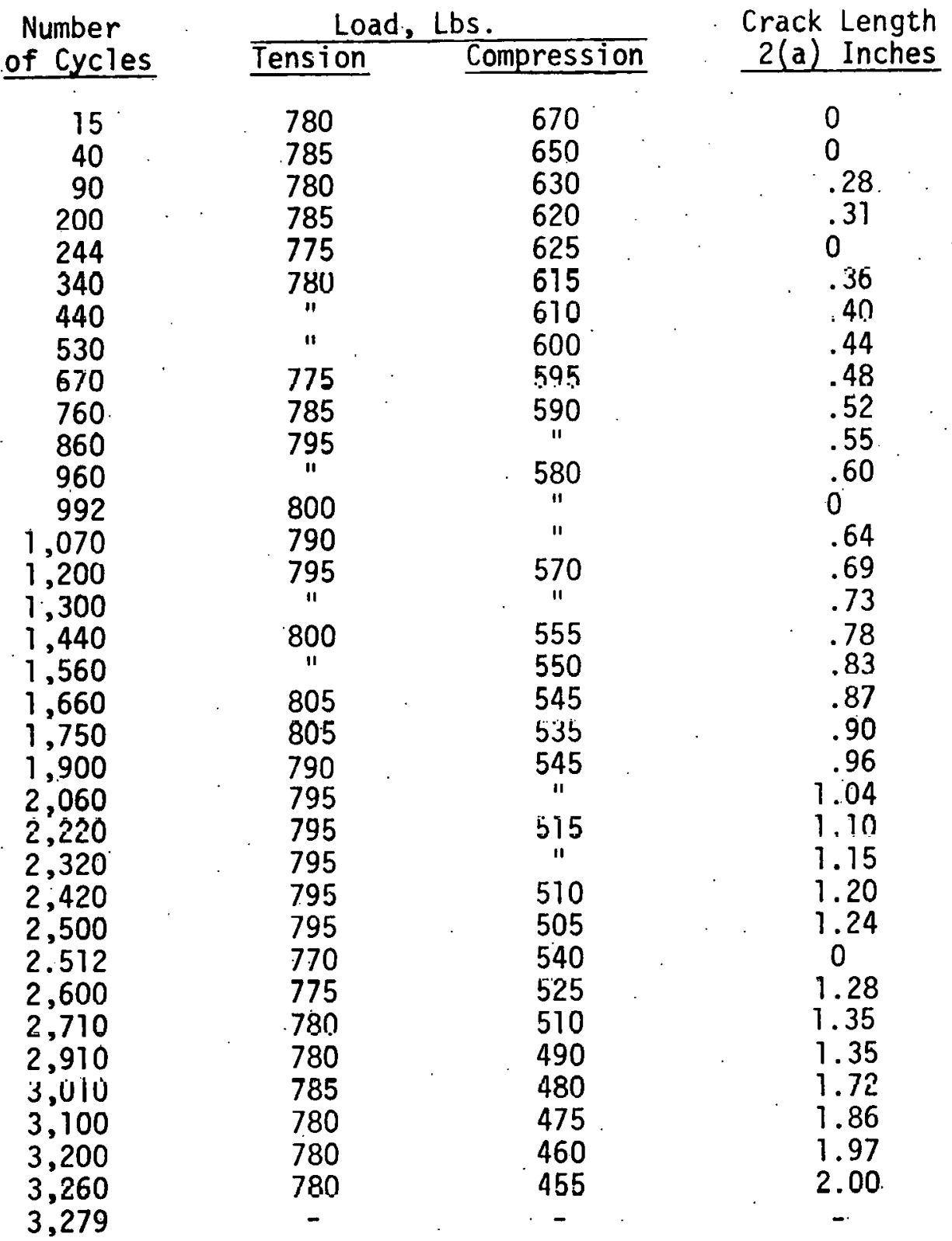


Spec: J-2-Bending

$A-212 B$

RT

Total Strain Range: $0.7 \%$

Moment Arm = not determined.

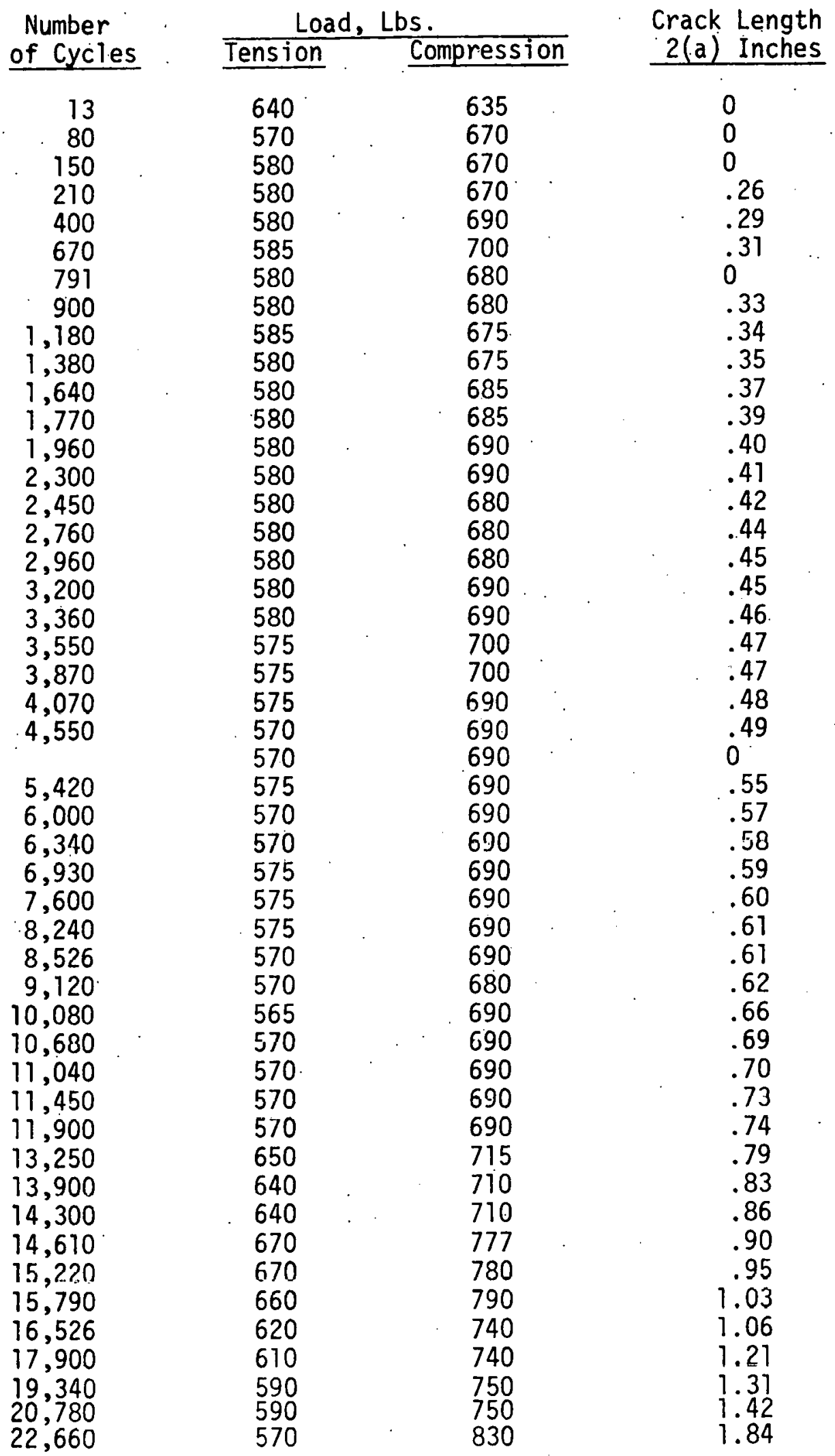


Spec: K-2-Bending

A-212B

RT

Total Strain Range: $1.0 \%$

Moment Arm - 9.3."

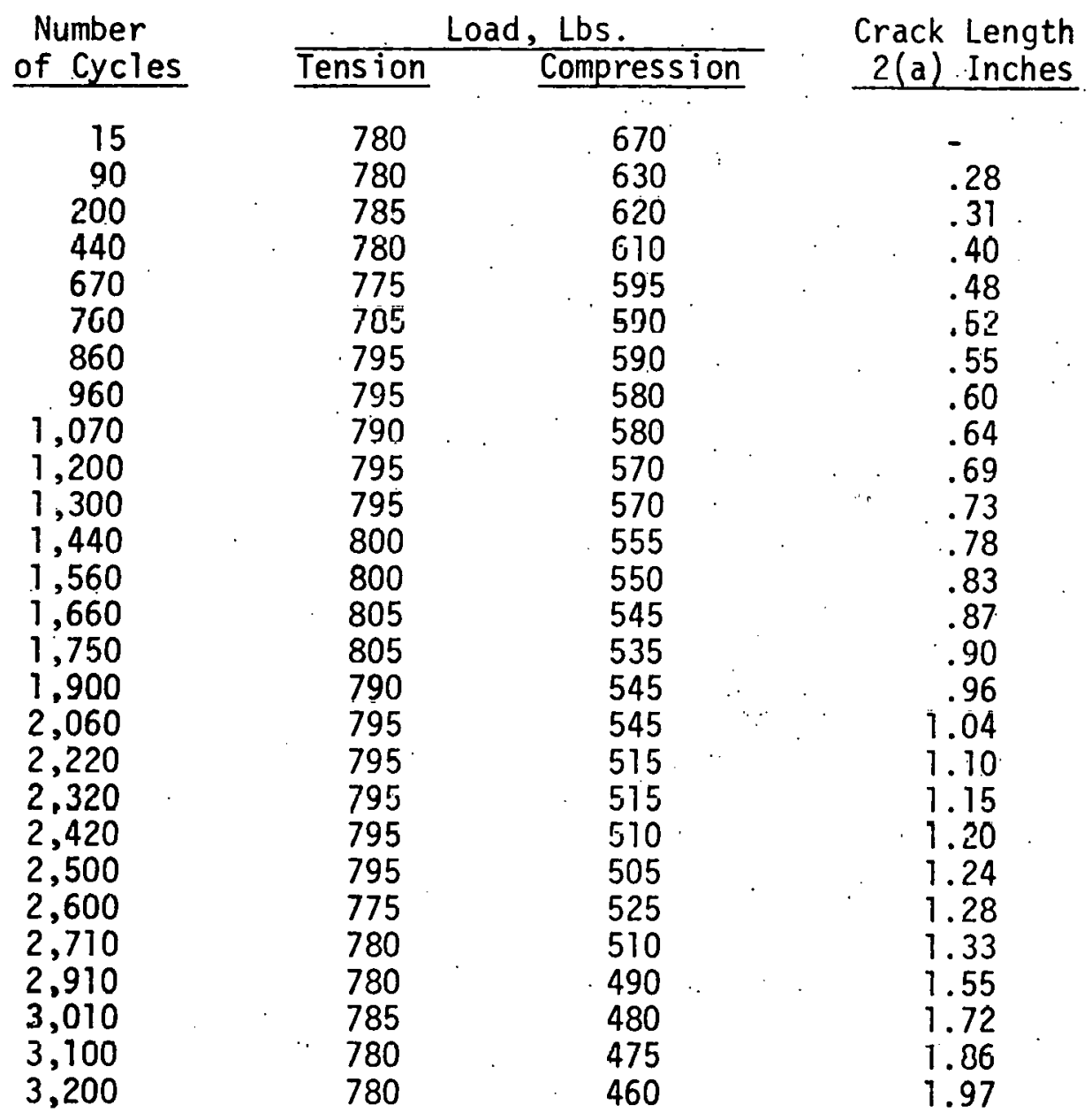


Spec: L-2-Bending

$A-212 B$

RT

Total Strain Range: $1.4 \%$

Moment Arm $=8.63^{\prime \prime}$

\begin{tabular}{|c|c|c|c|}
\hline $\begin{array}{c}\text { Number } \\
\text { of Cycles }\end{array}$ & $\frac{\text { LC }}{\text { Tension }}$ & $\begin{array}{l}\text { Lbs. } \\
\text { Compression }\end{array}$ & $\begin{array}{l}\text { Crack Length } \\
2(a) \text { Inches } \\
\end{array}$ \\
\hline 0 & 900 & 750 & .27 \\
\hline 60 & 860 & 730 & .30 \\
\hline 200 & 840 & 705 & .42 \\
\hline 320 & 830 & 680 & .50 \\
\hline 450 & $"$ & 670 & .60 \\
\hline 570 & 825 & 660 & .72 \\
\hline 680 & 820 & 650 & .83 \\
\hline 800 & $"$ & 645 & .93 \\
\hline 950 & 810 & 630 & 1.09 \\
\hline 1,080 & 805 & 615 & 1.21 \\
\hline 1,220 & 800 & 590 & 1.35 \\
\hline 1,325 & 795 & 585 & 1.49 \\
\hline 1,425 & 790 & 565 & 1.66 \\
\hline 1,520 & 785 & 545 & 1.70 \\
\hline 1,575 & 780 & 535 & 1.76 \\
\hline ו,757 & 750 & 525 & 2.09 \\
\hline
\end{tabular}


Spec: $M-2-B e n d i n g$

A-212B

$550^{\circ} \mathrm{F}$

Total Strain Range: $1.0 \%$

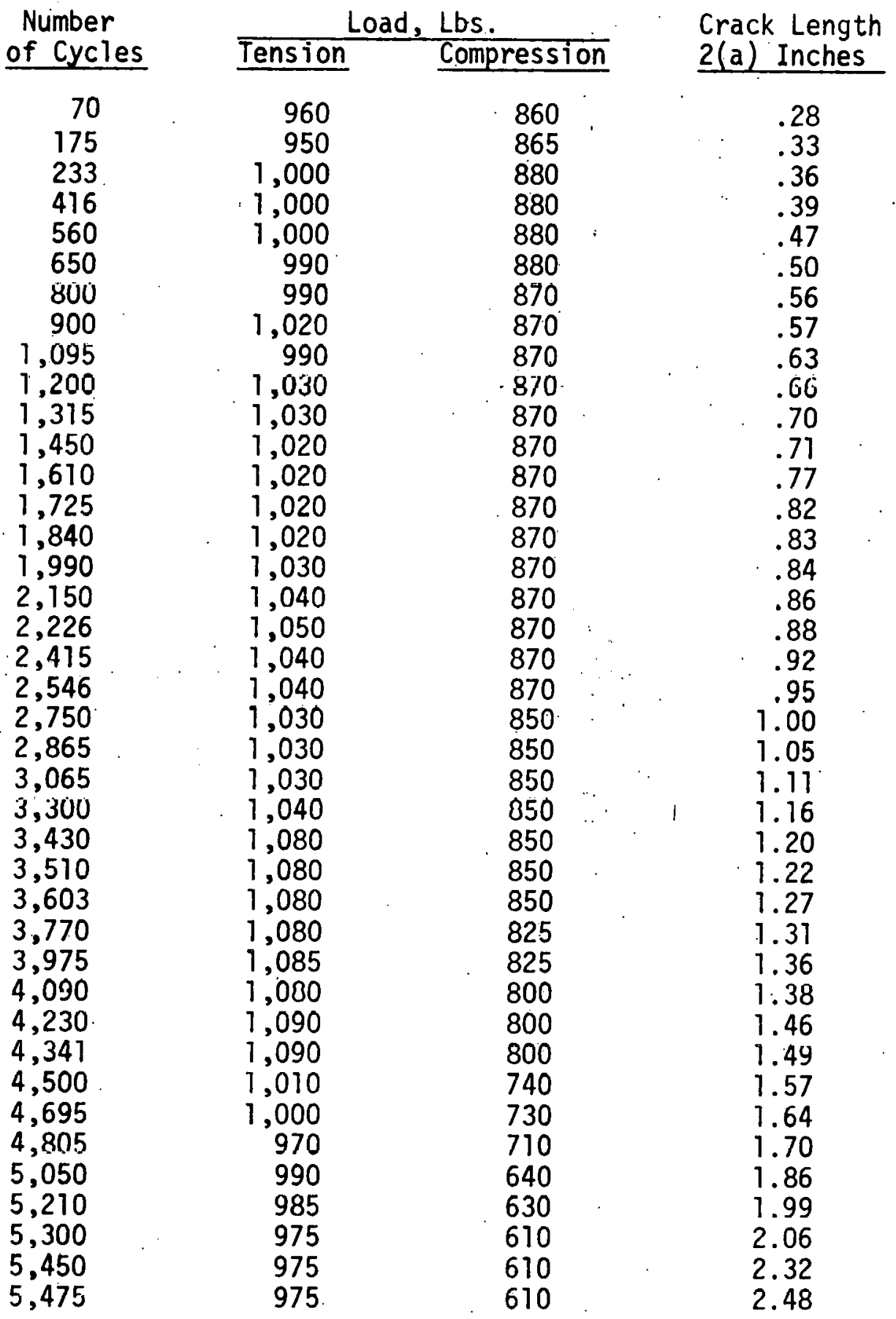


Spec: N-2-Bending

A-212B

$550^{\circ} \mathrm{F}$

Total Strain Range: $0.7 \%$

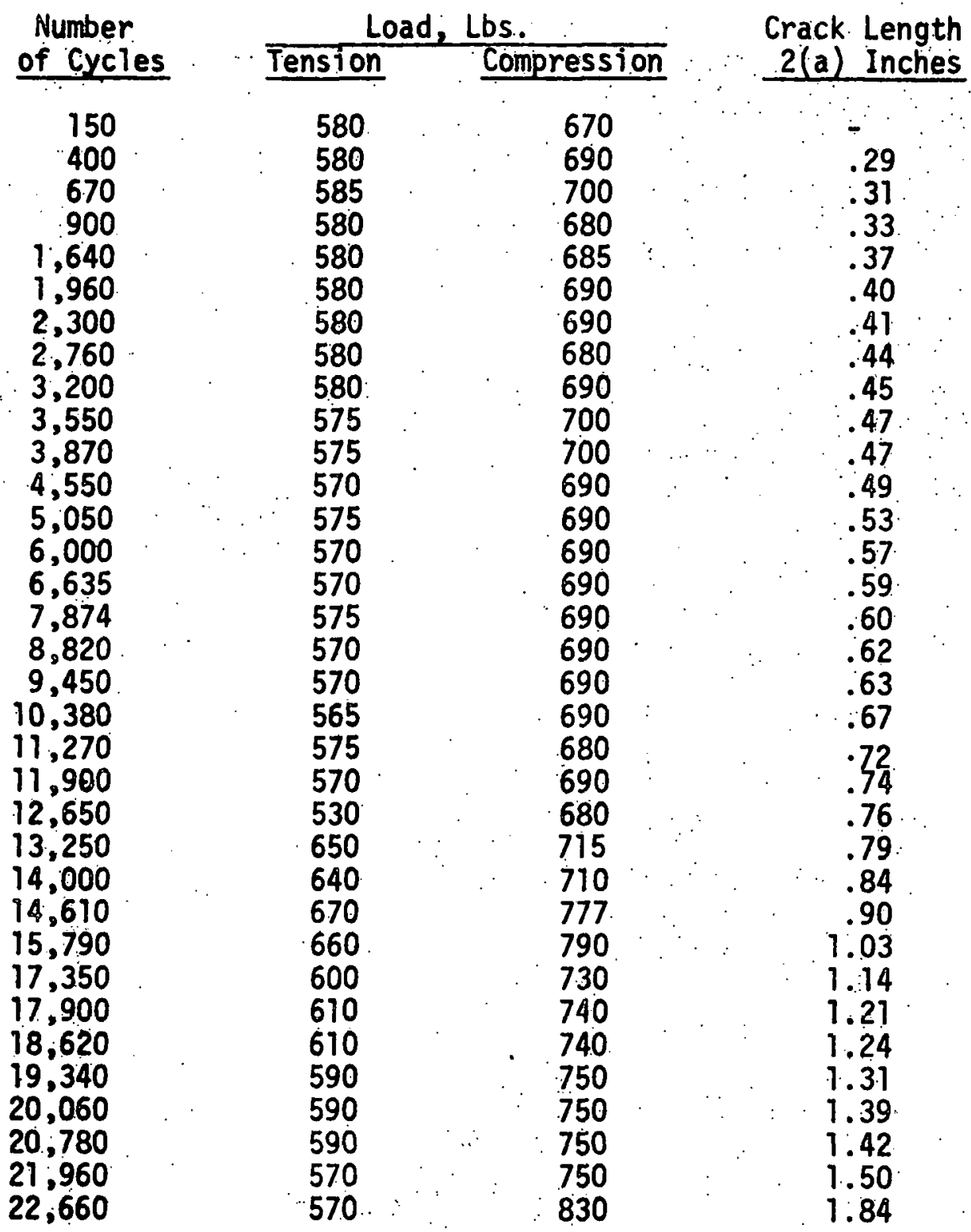


Spec: A-3-Axial

Type 304

RT

Total Strain Range: $0.18 \%$

\begin{tabular}{|c|c|c|}
\hline $\begin{array}{c}\text { Number } \\
\text { of Cycles }\end{array}$ & $\begin{array}{l}\text { Load } \\
\text { (Lbs.) }\end{array}$ & $\begin{array}{r}\text { Crack Length } \\
2(a) \text { Inches }\end{array}$ \\
\hline 1,000 & 30,500 & .76 \\
\hline 2,000 & 28,500 . & 1.0 \\
\hline 3,000 & 27,000 & 1.32 \\
\hline 4,000 & 25,000 & 1.60 \\
\hline 5,000 & 23,200 & 1.88 \\
\hline 6,000 & 21,000 & 2.12 \\
\hline 7,000 & 19,200 & 2.44 \\
\hline 8,000 & 17,000 & 2.72 \\
\hline 9,000 & 15,000 & 3.00 \\
\hline 10,000 & $1.3,000$ & 3.10 \\
\hline 11,000 & 12,000 & 3.20 \\
\hline 12,000 & 11,000 & 3.36 \\
\hline
\end{tabular}

88. 
Spec: B-3-Axial

Type 304

RT

Total Strain Range: $0.25 \%$

\begin{tabular}{ccc}
$\begin{array}{c}\text { Number } \\
\text { of Cycles }\end{array}$ & $\begin{array}{c}\text { Load } \\
\text { (Lbs.) }\end{array}$ & $\begin{array}{c}\text { Crack Length } \\
2 \text { (a) Inches }\end{array}$ \\
\hline 2,000 & 23,600 & $\vdots 1.48$ \\
3,000 & 22,200 & 1.60 \\
4,000 & 21,200 & 1.75 \\
5,000 & 20,000 & 1.87 \\
6,000 & 19,400 & 1.98 \\
7,000 & 19,000 & 2.10 \\
8,000 & 18,000 & 2.22 \\
9,000 & 17,000 & 2.32. \\
10,000 & 16,000 & 2.44.
\end{tabular}


Spec: $\quad C-3-A x i a l$

Type 304

RT

Total Strain Range: $0.4 \%$

\begin{tabular}{ccc}
$\begin{array}{c}\text { Number } \\
\text { of Cycles }\end{array}$ & $\begin{array}{c}\text { Load } \\
(\text { lbs.) }\end{array}$ & $\begin{array}{c}\text { Crack Length } \\
\text { 2(a) Inches }\end{array}$ \\
\hline 500 & 44,000 & 0.8 \\
1,000 & 40,400 & 1.20 \\
1,500 & 38,000 & 1.55 \\
2,000 & 35,000 & 1.75 \\
2,500 & 32,400 & 1.98 \\
3,000 & 30,000 & 2.20 \\
3,500 & 28,000 & 2.43 \\
4,000 & 25,400 & 2.65 \\
4,500 & 23,000 & 2.75 \\
5,000 & 20,000 & 3.10 \\
5,500 & 18,400 & 3.30 \\
6,000 & 16,000 & 3.50
\end{tabular}


Spec: D-3-Axial

Type 304

RT

Total Strain Range: $0.6 \%$

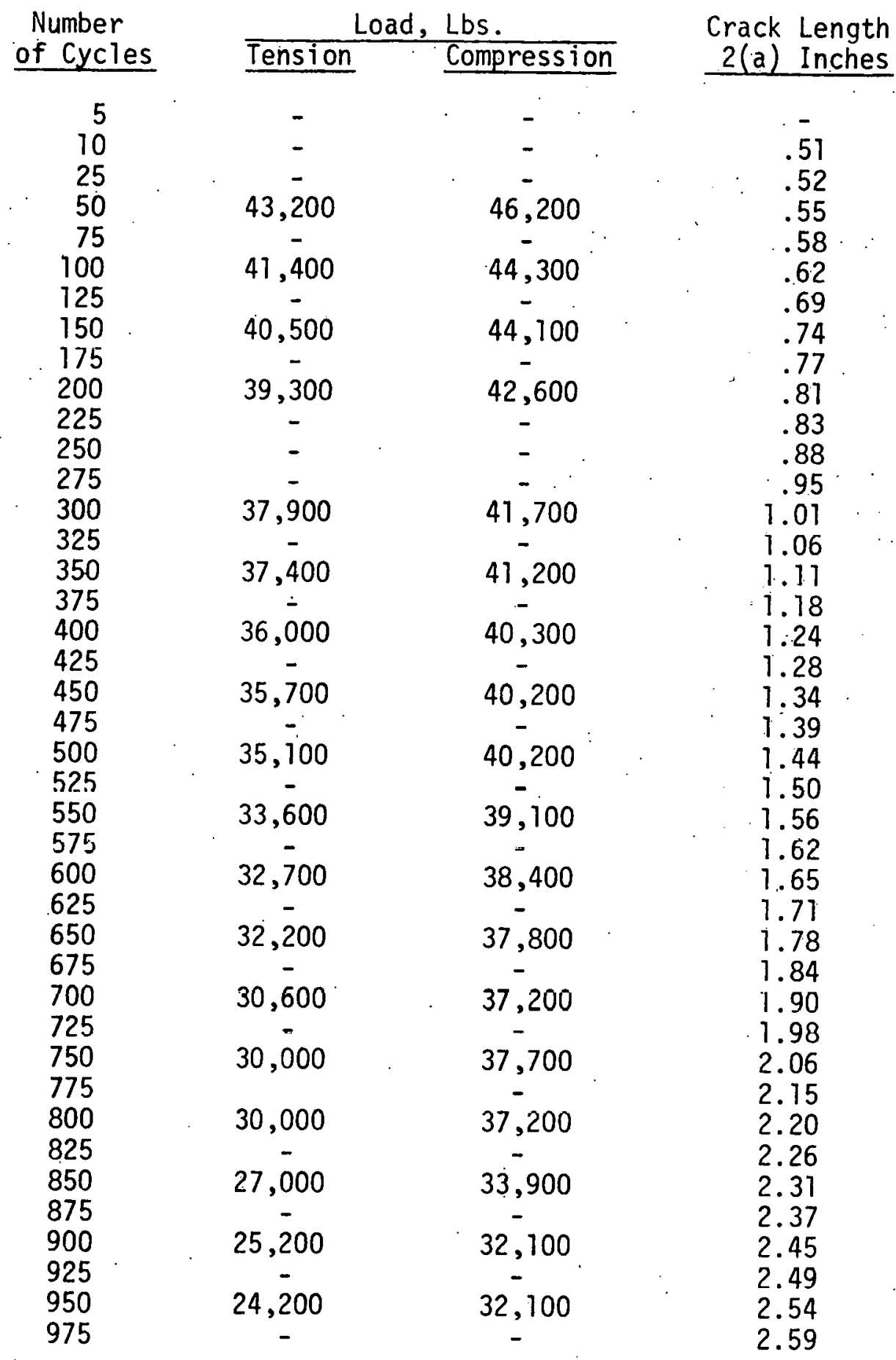

(cont'd.) 
Spec: D-3-Axial (cont'd.)

\begin{tabular}{|c|c|c|c|}
\hline Number & & , Lbs. & Crack Length \\
\hline of Cycles & Tension & Compression & 2(a) Inches \\
\hline 1,000 & 24,000 & 31,800 & 2.66 \\
\hline 1,025 & - & - & 2.74 \\
\hline 1,050 & 23,100 & 30,000 & 2.81 \\
\hline 1,075 & - & $0^{-}$ & 2.87 \\
\hline 1,100 & 22,200 & 28,400 & 2.94 \\
\hline 1,125 & - & - & 2.99 \\
\hline 1,150 & 20,200 & 27,500 & 3.06 \\
\hline 1,175 & - & - & 3.12 \\
\hline 1,200 & 19,200 & 25,800 & 3.17 \\
\hline 1,225 & - & $-x^{-}$ & 3.22 \\
\hline 1,260 & 18,800 & 26,100 & 3.28 \\
\hline 1,275 & 1740 & & 3.34 \\
\hline 1,300 & 17,400 & 26,000 & 3.40 \\
\hline $1 ; 325$ & i- & $0^{-} 00$ & 3.48 \\
\hline 1,350 & 14,100 & 20,800 & 3.57 \\
\hline 1,375 & $12-0$ & - & 3.64 \\
\hline 1,400 & 12,900 & 20,600 & 3.20 \\
\hline
\end{tabular}


Spec: E-3-Axial

GEAP-10181

Type 304

RT

Total Strain Range: $0.75 \%$

\begin{tabular}{|c|c|c|c|c|}
\hline $\begin{array}{l}\text { Number } \\
\text { of Cycles }\end{array}$ & \multicolumn{2}{|c|}{ Load, Lbs. } & $\begin{array}{r}\text { Crack } \\
2(a) \\
\end{array}$ & $\begin{array}{l}\text { Length } \\
\text { Inches }\end{array}$ \\
\hline 10 & 49,000 & 57,000 & & - \\
\hline 25 & - & - & & .56 \\
\hline 50 & 47,000 & 48,700 & & .62 \\
\hline 75 & - & - & & .75 \\
\hline 100 & 44,400 & 47,000 & & .86 \\
\hline 125 & 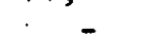 & - & & .95 \\
\hline 150 & 39,700 & 41,000 & & 1.14 \\
\hline 175 & - & - & & 1.26 \\
\hline 200 & 38,300 & 41,000 & & 1.38 \\
\hline 225 & - & - & & 1.51 \\
\hline 250 & 35,700 & 39,200 & & 1.64 \\
\hline 275 & 33,700 & 38,400 & & 1.86 \\
\hline 300 & 32,800 & 37,200 & & 1.97 \\
\hline 325 & 30,200 & 36,200 & & 2.10 \\
\hline 350 & - & - & & 2.24 \\
\hline 375 & - & - & & 2.36 \\
\hline 400 & 27,600 & 34,000 & & 2.49 \\
\hline 425 & - & - & & 2.60 \\
\hline 450 & 23,600 & 30,600 & & 2.72 \\
\hline 475 & - & - & & 2.85 \\
\hline 500 & 22,200 & 39,100 & & 2.98 \\
\hline 525 & - & - & & 3.09 \\
\hline 550 & 20,600 & 26,600 & & 3.20 \\
\hline 575 & - & - & & 3.29 \\
\hline 600 & 18,700 & 33,100 & & 3.38 \\
\hline 625 & - & - & & 3.48 \\
\hline 650 & 16,900 & 28,600 & & 3.56 \\
\hline 675 & - & - & & 3.64 \\
\hline 700 & 15,300 & 29,600 & & 3.70 \\
\hline 725 & - & - & . & 3.75 \\
\hline 750 & 14,700 & 29,800 & & 3.80 \\
\hline 7.75 & - & - & & 3.86 \\
\hline 800 & 13,200 & 29,700 & & 3.92 \\
\hline 825 & - & - & & 3.98 \\
\hline
\end{tabular}


Spec: F-3-Axial

$\mathrm{RT}$

Total Strain Range: $1.0 \%$

\begin{tabular}{ccc}
$\begin{array}{c}\text { Number } \\
\text { of Cycles }\end{array}$ & $\begin{array}{c}\text { Load } \\
\text { (lbs.) }\end{array}$ & $\begin{array}{c}\text { Crajck } \text { Length } \\
\text { 2(a) Inches }\end{array}$ \\
\hline 200 & 39,500 & 1.05 \\
300 & 36,000 & 1.40 \\
400 & 32,500 & 1.75 \\
500 & 29,500 & 2.06 \\
600 & 26,000 & 2.40 \\
700 & 23,250 & 2.66 \\
800 & 21,000 & 2.90 \\
900 & 18,250 & 3.15 \\
1,000 & 16,250 & 3.45 \\
1,100 & 13,500 & 3.76 \\
1,200 & 10,500 & 4.06 \\
1,300 & $8,2 b 0$ & 4.35 \\
\hline 3500 & &
\end{tabular}




\section{REFERENCES}

1. Brothers, A. J., Fatigue Crack Growth in Nuclear Reactor Piping Steels, GEAP-5607, March 1968.

2. Gross, M. R., "Low-Cycle Fatigue of Materials for Submarine Construction," Naval Engineers Journal, October 1963, p. 783.

3. Crooker, T. W., and Lange, E. A., "Low-Cycle Fatigue Crack Propagation Resistance of Materials for. Large Welded Structures," ASTM STP 415, Fatigue Crack Propagation, June 1966.

4. Paris, P. C., and Sih, G. C., "Stress Analysis of Cracks," Book: Fracture Toughness Testing and Its Applications, ASTM STP 381 .

5. Brown, W. F., and Srawley, J. E., "Plane Strain Crack Toughness Testing of High Strength Metallic Materials", Book: ASTM STP 410.

6. Kobayashi, A. S., On The Magnification Factors of Deep Surface Flaws Boeing Airplane Co., Structural Development Research Memorandum No. 16, December 1965.

7. Smith, F. W., Stress Intensity Factors for a Semi-Elliptical Surface Flaw, Boeing Airplane Co., Structural Development Research Memorandum, No. 17 August 1966.

8. Mathematical Tables from Handbook of Chemistry and Physics, Eighth Edition, p. 211.

\section{ACKNOWLEDGMENTS}

The work reported here was performed through financial support of the Atomic Energy Commission [Contract AT(04-3)-189PA37]. The author gratefully acknowledges the careful, constructive, and critical review of the report by Dr. R. M. Goldhoff and Mr. F. D. Lordi. 


\section{DISTRIBUTION}

Aerojet General

Engineering Division

Sacramento Plant

Sacramento, California 95801

Atn. Dr. F.J. Climent

Advisory Committee on Reactor Safeguards Dr. Spencer H. Bush

Consultant to the Director

Battelle Memorial Institute

Pacific Northwest Laboratory

Richland, Washington 99352

Advisory Committee on Reactor Safeguards $\mathrm{Mr}$. Harold Etherington

84 Lighthouse Drive

Jupiter, Florida 33458

Advisory Committee on Reactor Safeguards Dr. William L. Faith

2B400 Huntingron Drive

San Marino, California 91108

Advisory Committee on Reactor Safeguards Dr. Chester P. Siess

Department of Civil Engineering

3129 Civil Engineering Bldg.

University of Illinois

Urbana, Illinois 61801

Advisory Committee on Reactor Safeguards Dr. Stephen H. Hanauer

Professnr of Nuclear Fongineering

606 Dougherty Hall

University of Tennessee

Knoxville, Tennessee 37916

Advisory Committee on Reactor Safeguards Dr. Joseph M. Hendrie

Nuclear Enginccring Department

Brookhaven National Laboratory

Upton, New York 11973

Advisory Committee on Reactor Safeguards Dr. Herbert s. I sbin

Department of Chemical Engineering

Unlversity of Minutesuta

Minneapolis, Minnesota 55455

Advisory Committee on Reactor Safeguards Mr. Ilarold Li. Mangelsdort

78 Knollwood Road

Short Hills, New Jersey 07078

Advisory Committee on Reactor Safeguards Dr. Harry O. Monson, Senior Engineer Laboratory Director's Óffice

Argonne National Laboratory

9700 South Cass Avenue

Argonne, Illinois 60439

Advisory Committee on Reactor Safeguards Dr. Arlie A. O'Kelly

2421 West Rowland Avenue

Littleton, Colorado 80120
1 . Advisory Committee on Reactor. Safeguards

Dr. David Okrent, Senior Physicist

Laboratory Director's Office

Argonne National Laboratory

9700 South Cass Avenue

1

Argonne, Illinois 60439

Advisory Committee on Reactor Safeguards

1

Dean Nunzio J. Palladino

College of Engineering

The Pennsylvania State University

101 Hammond Building

1

University Park, Pennsylvania 16802

Advisory Committee on Reactor Safeguards

Dr. William R. Stratton

Los Alamos Scientiflc Laboratory

P. O. Box 1663

1 Los Alamos, New Mexico 87544

Advisory Committee on Reactor Safeguards

Director of Research

University of Houston

Cullen Boulevard

Houston, Texas $77004^{\circ}$.

Mr. Raymond F. Fraley

3

1 Advisory Committee on Reactor Safeguards

U.S. Atomic Energy Commission

Room 1034-H

Washington, D.C. 20545

Argonne National I ahoratory

9700 South Cass Avenue

Argonne, Illinois

Attn: Mr. Paul G. Shewmon

Argonne National Laboratory

9700 South Cass Avenue

Argonne, lllinois

1 Attn: Dr. P. Lottes

Aragonne National Laboratory

9700 South Cass Avenue

Argonne, Illinois

1

Attn: Dr. C.E. Dickermall

Argonne National Laboratory

9700 South Cass Avenue

Argonne, Illinois

1

Attn: Dr. R.O. Ivins

Argonne National Laboratory

9700 South Cass Avenue

Argonne, lllinois

Attn: Dr. S. Fistedis

1 Argonne National Laboratory 9700 South Cass Avenue

Argonne, Illinois

Attn: Dr. R.C. Vogel 
Argonne National Laboratory

9700 South Cass Avenue

Argonne, Illinois

Attn: LMFBR Program Office

Argonne National Laboratory

9700 South Cass Avenue

Argonne, lllinois

Attn: Mr. A. Amorosi

Argonne National Laboratory

9700 South Cass Avenue

Argonne, Illinois

Attn: Dr. L. Baker

Atomic Energy Commission

Division of Reactor Development and Technology

Washington, D.C. 20545

Attn: Col. R.L. Ednie

Asst. Director for Army Reactors

Atomic Energy Commission

Division.of Reactor Development and Technology

Washington, D.C. 20545

Attn: Mr. M.A. Rosen

Asst. Director for Plant Engineering

Atomic Energy Commission

Division of Reactor Development and Technology

Washington, D.C. 20545

Attn: Mr. M.J. Whitman

Asst. Director for Program Analysis

Atomic Energy Commission

Division of Reactor Development and Technology

Washinintur, D.C. 20545

Attn: Dr. E.E. Sinclair

Asst. Director for Reactor Technology

Atomic Energy Commission

Division of Reactor Development and Technology

Washington, D.C. 20545

Attn: Mr. A. Giambusso

Asst. Directur fur Projecr Management

Atomic Energy Commission

Division of Rsactor Development and Technology

Washington, D.C. 20545

Attn: Mr. E.E. Kintner

Asst. Director for Reactor Engineering

Atomic Energy Commission

Division of Reactor Development and Technology

Washington, D.C. 20545

Attn: Mr. J.W. Crawford

Asst. Director for Engineering Standards

Atomic Energy Commission

Division of Compliance, Region IV

10395 West Colfax Avenue

Denver, Colorado 80215

Attn: Mr. John W. Flore

Atomic Energy Commission

Division of Compliance

Washingtüii, D.C. 20545

Attn: Mr. L. Kornblith, Jr.
$1 \quad$ Atomic Energy Commission

Division of Operational Safety

Washington; D.C. 20545

Attn: Mr. H. Gilbert

2 Atomic Energy Commission

Division of Reactor Standards

Washington, D.C. 20545

Attn: Mr. E.G. Case

Atomic Energy Commission

Division of Reactor Standards

Washington, D.C. 20545

Attn: Mr. M. Bolotsky

Atomic Energy Commission

Division of Reactor Standards

Washington, D.C. 20545

Attn: Mr. A.B. Holt

Atomic Energy Commission

Division of Reactor Standards

Washington, D.C. 20545

Attn: Mr. R. Waterfield

Atomic Energy Commission

Division of Reactor Standards

Washington, D.C. 20545

Attn: Dr. G. Burley

Atomic Energy Commission

Division of Reactor Standards

Washington, D.C. 20545

Attn: Mr. R. Impara

Atomic Energy Commission

Water Projects Branch

Division of Reactor Development and Technology

Washington, D.C. 20545

Attn: Mr. W.H. Layman

Atomic Energy Commission

Naval Reactors Branch

Divisiori of Reactor Development and Technology

Washington, D.C. 20545

Attn: Mr. R.S. Brodsky

Atomic Eneryy Commission

Division of Reactor Development and Technology Washington, D.C. 20545

Attn: A.J.Pressesky

Atomic Energy Commission

Division of Reactor Development and Technology Washington, D.C. 20545

Attn: Mr. S.A. Szawlewicz

Atomic Energy Commission

Division of Reactor Development and Technology

Washington, D.C. 20545

Attn: Mr. R.R. Newton

1 Atomic Energy Commission

Division of Production

Washıngton, D.C. 20545

Attn: Mr. George B. Pleat 
Átómic Energy Commission c/o Gulf General Atomic, Inc. P.O. Box 608

San Diego, California 92112

Attn: Mr. Russell H. Ball

Atomics International

P.O. Box 309

Canoga Park, California

Attn: Dr. H. Morewitz

Babcock \& Wilcox Company

Washington Operations Office

1725 I Street, N.W.

Washington,D.C. 20006

Babconk \& Wilnox Company

P.O. Box 1260

Lyıliluurğ, Virginia

Attn: Mr. Robert Wascher

Battelle Memorial Institute

505 King Avenue.

Columbus, Ohio 43201

Attn: Dr. D.N. Sunderman

Battelle Memorial Institute

505 King Avenue

Columbus, Ohio 43201

Attn: Dr. D.L. Morrison

Battelle Memorial Institute

505 King Avenue

Culumbus, Oliiu 43201

Attn: Mr. S. Paprocki

Batlelle Meiiniórial Institute

B06 King Avenue

rnlımhıs, Ohio 43201

Attn: Mr. À.R. Duffy

Brookhaven National Laboratory

Upton, Long Island, New York 11973

Attn: A.W. Castleman

University of Calitornia

Institute of Engineering Research

Berkeley, California $94 \% 4$

Attn: Prof. V.E. Schrock

I Iniversity of California

Institute of Engineering Research

Berkeley, California 94704

Attn: Prof. H.A. Johnson

\section{Canoga Park Area Office}

P.O. Box 591

Canoga Park, California 91305

Attn: Mr. R.L. Morgan RDT Senior Site Rep.

Combustion Erigineering, Inc.

Nuclear Division

P.O. Box 500

Windsor. Connecticut 06095

Attn: Mr. M.F. Valerino
1 Chicago Operations Office

Atomic Energy Commission

9800 South Cass Avenue

Argonne, Illinois 60439

Attn: Mr. D.M. Gardiner

2

Douglas United Nuclear

1

Richland, Washington

Attn: Mr. John Riches

Harvard Air Cleaning Laboratory

1 Harvard University

665 Huntington Avenue

Boston, Massachusetts 02190

IIT Research Institute

110 W. 35th Street

Chicago, Illinnis 60616

Attn: Dr. T.A. Yaker

IIT Research Institute

210 W. 3bth street

Chicago, Illinois 60616

Attn: Mr. E.V. Gallagher

Idaho Operations Office

1 Atomic Energy Commission

P.O. Box 2108

Idaho Falls, Idaho 83401

Attn: Mr. D. Williams

2

Liquid Metal Engirreering Center

c/o ^tomics International

P.O. Box 309

Canoga Park, California 91304

1

Attn: R.W. Dick.inson

Los Alamos Scientific Laboratory

PÜ. Box $16 \bar{b}$

Los Alamos, New Mexico 87544

1 Attn: Mr.J.H. Russel, K Division

MPR Associates, Inc.

Washingion, D.C. $\mathbf{2 0 0 3 0}$

Attn: Mr. T. Rockwell III Chalrman AIF Salety Task Fuice

National Buroau onf Standards

1 Washington, D.C. 20545

Attn: Drr. C. Muehihause

Naval Ordnance Laboratory

1 Silver Spring, Maryland

Attn: Mr. James Proctor

North Carolina State University

Department of Mechanical Engineering

Raleigh, North Carolina 27607

Attn: Prof. M.N. Ozisik

Nuclear Fuels Services 
Oak Ridge Operations Office Atomic Energy Commission Oak Ridge, Tennessee 37830 Attn: Mr. W.L. Smalley

Oak Ridge National Laboratory Nuclear Safety Information Center P.O. Box $Y$

Oak Ridge, Tennessee 37830

Attn: Mr. Joel Buchanan

Chemical Technology Division Oak Ridge National Laboratory P.O. Box $Y$

Oak Ridge, Tennessee 37830

Attn: Mr. D. Ferguson

Chemical Technology Division

Oak Ridge National Laboratory P.O. Box $Y$

Oak Ridge, Tennessee 37830

Attn: Mr. R. Blanco

Oak Ridge National Laboratory

P.O. Bux Y

Oak Ridge, Tennessee

Attn: HTGR Safety Program Office

Oak Ridge National Laboratory

P.O. Box Y

Oak Ridge, Tennessee

Attn: Mr.W. B. Cottrell

Oak Ridge National Laboratory

P.O. Box $Y$

Dak. Ridge, Tennessee

Attn: Mr.P. Rittenhouse

Pacific Northwest Laboratories

P.O. Box 999

Richland, Washington 99352

Attn: Mr. G. Rogers

Parifir: Nnrthweast Lahnratnries

P.O. Box 999

Richland, Washington 99352

Attn: Mr. J.C. Spanner

Pacific Northwest Laboratories

P.O. Box 999

Richland, Washington 99352

Attn: Dr. J. Batch

Pacific Northwest Laboratories

P.O. Box 393

Richland, Washington 99352

Attn: Mr. R. Nightingale

Pacific Northwest Laboratories

P.O. Box 999

Richland, Washington 99352

Attn: Mr. L. Schwendiman.
1 Pacific Northwest Laboratories P.O. Box 999

Richland, Washington 99352

Attn: Mr. E.R. Astley, Mgr. FFTF

1 Idaho Nuclear Corporation

P.O. Box 1845

Idaho Falls, Idaho 83401

Attn: Mr. Curt Haire

Idaho Nuclear Corporation

1 P. O. Box 1845

Idaho Falls, Idaho 83401

Attn: Mr. S. O. Johnson

Idaho Nuclear Corporation

P.O. Box 1845

1 Idaho Falls, Idaho 83401

Attn: Mr. H. L. Coplen

Idaho Nuclear Corporation

P. O. Box 1845

Idaho Falls, Idaho 83401

2

Attn: Mr. O. F. Brockett

Idaho Nuclcar Corporation

P. O. Box 1845

Idaho Falls, Idaho 83401

4. Attn: Water Reactor Safety Program Office, Mr. G. O. Bright, Mgr.

Richland Operations Office

P.O. Box 500

$1 \quad$ Richland, Washington 99352

Attn: Mr. C. Robinson

Richland Operations Office

P.O. Box 500

$1 \quad$ Richland, Washington 99352

Attn: Mr. A.S. Waterhouse

Richland Operations Office

P.O. Box 500

$1 \quad$ Richland, Washington 89362

Attn: Mr. A. Brunstad

San Francisco Operations Office

Atomic Energy Commission

2111 Bancroft Way

Berkeley, California 94704

Attn: Mr. C.V. Backlund

Savannah River Laboratories

E.l.duPont deNemours and Company

Aiken, Süuth Car oulinı 29802

Attn: Mr. A.H.Peters

TRW Inc.

1 TRW Systems Group

One Space Park

Redondo Beach, California 90278

Attn: Dr. D. B. Langmuir 
TRW Inc.

TRW Systems Group

One Space Park

Redondo Beach, California 90278

Attn: Mr. S.M. Zivi

Westinghouse Electric Corporation

Atomic Power Division .

P.O. Box 355

Pittsburgh, Pennsylvania 15230

Attn: Mr.R.A. Wiesemann

Westinghouse Electric Corporation

Atomic Power Division

P.O. Box 355

Pittsburgh, Pennsylvania 15230

Atțn: Dr, D, Flețçer

Westinghouse Electric Corporation Aromlc Power Division

P.O. Box 355

Pittsburgh, Pennsylvania 15230

Attn: Dr. E. Beckjord

Westinghouse Electric Corporation

P.O. Box 19218

Tampa, Florida 33616

Attn: Mr. A. Lohmeier

Southern Nuclear Engineering, Inc. P.O. Box 10

Dunedin, Florida 33528

Attn: Mr. Gilbert Brown

Holmes \& Narver, Inc.

828 Suuth, Fiyueiud St.

Los Angeles, California 90017

Attn: B. Shimizu

Mr. Edward T. Wessel

Research and Development Center

Westinghouse Electric Corporation

Bculah Road, Churchill Boro

Pittsburgh, Pennsylvania 15235

Dr. William E. Cooper

Teledyne Materials Research

303 Bear Hill Road

Waltham. Massachusetts

Roger W. Staehle

Metallurgy Department

Ohio State University

Columbus, Ohio

Mr. Ralph Jones

Division of Reactor Development

U.S. Atomic Energy Commission

Washington 25, D.C.

Mr. H.K. Marks

Room 2 N83

Department of the Navy

Washington, D.C.
H. Thielsch

140 Shaw Avenue

Cranston 5, Rhode Island

Mr. F.M. Moschine

1

1

Westinghouse Electric Company

Atomic Power Department

P.O. Box 355

Pittsburgh, Pennsylvania 15230

Dr.P. L. Pfenningwerth

1

$1 \quad$ P.O. Box 79

West Mifflin, Pennsylvania 15122

Professor C.E. Taylor

1

Department of Theoretical and Applied Mechanics

University of Illinois

1

Urbana, Illinois

Mr. E. Beauchamp.Nobus

U.S. Marine Engineering Laboratory

Annapolis, Maryland

U.S. Atomic Energy Commission

Division of Technical Information Extension

P.O. Box 62

Oak Ridge, Tennessee

U.S. Atomic Energy Commission

Division of Reactor Licensing

Washington, D.C. 20545

Attn. S.S. Pantlirki

USAEC Site Representative

i General Electrir Company

Sunnyvale. California 94086

Attn: Joel Levy, Senior Site Rep.

Mr. B.L. Greenstreet

1 P.O.Box Y

Oak Ridge National Laboratory

Oak Ridge, Tennessee

Mr. F.J. Witt

P.O. Box Y

ORNL - Oak Ridge, Tunnessee

Commonwealth Edison Company

Dresden Nuclear Power Station

Rural Route 1

Morris, Illinois 60450

1 Attn: H.K. Hoyt

Commonwealth Edison Company

System Mechanical and Structural Engineer

72 West Adams Street

1 Chicago, Illinois 60690

Attn: N.A. Kershaw

United Kingdom Atomic Energy Authority

1

1 Wigshaw Lane, Culcheth

Warrington, Lancs.

England

Attn: R.W. Nichols 
Atomic Energy of Canada Limited Chalk River Nuclear Laboratories Chalk River, Ontario, Canada Dr. George Pon

Mr. Robert D. Wylie

Department of Materials Engineering

Southwest Research Institute

8599 Culebra Road

San Antonio, Texas 78228

O.A. Kellerman

Institut Fur Reaktorsicherheit

Der Technischen Uberwachungs

Vereine, e.V.

5 Koln - Ehrenfeld, Lukasstr. 90

West Germany

C. A. G. Phillips

U.K.A.E.A. Safeguards Division

Authority Health \& Safety Branch

Risley, Warrington, Lancashire

England

Knolls Atomic Power Laboratory

P. O. Box 1072

Schenectady, New York 12301

Attn: Dr. Robert A. Barnes

Reactor Materials Branch

Metallurgy Division

Naval Research Laboratory

Washington, D. C. 20545

Attn: Mr. L. E. Steele
1 Department of Material Science \& Engineering

Hearst Mining Building

University of California

Berkeley, California

Attn: Mr. William W. Gerberich

1

United Engineers and Constructors, Inc.

1401 Arch Street

Philadelphia, Pennsylvania 19105

Attn: Mr. John Crowley

1

Argonne National Laboratory

1

9700 South Cass Avenue

Argonne, llinois

Attn: Mr. Craig Cheng

AEG Telefunken

1

AEC Hochhaus Sued

6 Frankfurt/Main 70

West Germany

Attn: Mr. Dieter Ewers

Division of Reactor Development \& Technology

1 U.S. Atomic Energy Commission

Washington, D.C. 20545

Attn: J. R. Hunter

Asst. Director, Instruction Division.

$1 \quad$ U.S. Atomic Energy Commission

Chicago Operations Office

9800 South Cass Avenue

Argonne, Illinois 60439

Attn: R. M. Moser 